NBER WORKING PAPER SERIES

\title{
THE LONG RUN IMPACTS OF MERIT AID: EVIDENCE FROM CALIFORNIA'S CAL GRANT
}

\author{
Eric Bettinger \\ Oded Gurantz \\ Laura Kawano \\ Bruce Sacerdote \\ Working Paper 22347 \\ http://www.nber.org/papers/w22347 \\ NATIONAL BUREAU OF ECONOMIC RESEARCH \\ 1050 Massachusetts Avenue \\ Cambridge, MA 02138 \\ June 2016
}

\begin{abstract}
We thank Ariella Kahn-Lang for superb research assistance, Nicholas Turner for assistance with the federal student aid data, and the staff of the California Student Aid Commission for providing the data access and institutional knowledge that made this project possible. Helpful comments and suggestions were provided by participants at the following conferences and presentations: NBER Public Economics, National Tax Association, U.S. Department of the Treasury, Williams College, Association of Public Policy and Management, Association for Education, Finance, and Policy. Eric Bettinger and Oded Gurantz thank the Spencer Foundation for financial support. Eric Bettinger, Oded Gurantz and Bruce Sacerdote thank the Smith Richardson Foundation for financial support and acknowledge support by grant \#R305B090016 from the U.S. Department of Education, Institute of Education Sciences. The views expressed in this paper are those of the authors and do not necessarily reflect the policy of the U.S. Department of the Treasury or the National Bureau of Economic Research.
\end{abstract}

NBER working papers are circulated for discussion and comment purposes. They have not been peer-reviewed or been subject to the review by the NBER Board of Directors that accompanies official NBER publications.

(C) 2016 by Eric Bettinger, Oded Gurantz, Laura Kawano, and Bruce Sacerdote. All rights reserved. Short sections of text, not to exceed two paragraphs, may be quoted without explicit permission provided that full credit, including $\odot$ notice, is given to the source. 
The Long Run Impacts of Merit Aid: Evidence from California's Cal Grant

Eric Bettinger, Oded Gurantz, Laura Kawano, and Bruce Sacerdote

NBER Working Paper No. 22347

June 2016

JEL No. H2,H4,H41,H52,I2,I22,I23,I24

\section{ABSTRACT}

We examine the long-term impacts of California's state-based financial aid by tracking students' educational and labor force outcomes for up to 14 years after high school graduation. We identify program impacts by exploiting variation in eligibility rules using GPA and family income cutoffs that are ex ante unknown to applicants. Aid eligibility increases undergraduate and graduate degree completion, and for some subgroups, raises longer-run annual earnings and the likelihood that young adults reside in California. Aid eligibility has no impact on take-up of the Pell or federal tax credits for higher education. These findings suggest that the net cost of financial aid programs may frequently be overstated, though our results are too imprecise to provide exact cost-benefit estimates.

Eric Bettinger

Stanford School of Education

CERAS 522, 520 Galvez Mall

Stanford, CA 94305

and NBER

ebettinger@stanford.edu

Oded Gurantz

Stanford University, College Board

ogurantz@stanford.edu
Laura Kawano

Department of the Treasury

laurakawano@gmail.com

Bruce Sacerdote

6106 Rockefeller Hall

Department of Economics

Dartmouth College

Hanover, NH 03755-3514

and NBER

Bruce.I.Sacerdote@dartmouth.edu 
Educational investment is widely considered a key input into economic growth (Hanushek \& Woessmann, 2015). Although primary and secondary education has been compulsory and free in the United States for decades, postsecondary education remains both optional and increasingly expensive, even as a college degree has essentially become a requirement for stable employment. The cost of college provides a rationale for government intervention into postsecondary financing, particularly through targeted loans and grants needed to reduce financial constraints for low-income students (Becker, 1975). Whereas research has begun to examine the long-term impacts of government investment in a variety of educational policy areas, there is less such research in the postsecondary sector. ${ }^{1}$

State programs that allocate aid based on either need or merit considerations have become more prominent over the past two decades, with funding increasing by $83 \%$ from 2002 to 2012 (NASSGAP, 2012). Merit-aid programs in particular have expanded from Arkansas and Georgia in the early 1990s to over twenty state programs (Domina, 2014; Doyle, 2006). However, there is relatively little research to date that would allow financial aid programs to measure their long-run return on investment. Causal impacts of financial aid have been predominately restricted to short-term college attendance and bachelor's degree completion outcomes. Recent work in other areas, such as early childhood education, suggest that a program's long-term impacts may swamp short-term gains (Chetty et al., 2011; Dynarski et al., 2013) and that educational programs may actually pay for themselves through increased future tax revenues (Bettinger et al., 2016). Evaluating the ultimate returns to financial aid requires policymakers to observe a diverse set of outcomes, including labor force decisions, mobility, health, family formation and other economically critical decisions. This requires the ability to follow students over a much longer time-frame than has previously been available.

We examine the impacts of California's Cal Grant program, one of the largest and most generous state-based financial aid programs, as measured by number of students and overall expenditure. ${ }^{2}$ The Cal Grant system contains a number of features that make it ideal for examining financial aid's long-term causal impact. First, eligibility for the grant is based on a series of strict cutoffs

\footnotetext{
${ }^{1}$ For example, economists have examined the long-term impacts of inputs into early childhood (Chetty et al., 2011), primary school (Dynarski, Hyman, \& Schanzenbach, 2013), or secondary school (Jackson, Johnson, \& Persico, 2016) settings.

${ }^{2}$ For example, the Cal Grant awarded over $\$ 1.6$ billion in grants for the 2013-14 academic year.
} 
in family income and high school GPA. Crucially, in the years of our analysis, the locations of these cutoffs were not known to applicants ahead of time. These eligibility thresholds allow us to use a regression discontinuity design to identify two subpopulations of students: (1) students who are income-eligible but whose GPAs are near the minimum GPA cutoff; and (2) students who are GPA-eligible but whose family incomes are near the income threshold. These discontinuities represent separate populations - the first group are generally low-income, low-GPA high school graduates, whereas the second group contains a range of GPAs for middle-income families - and the heterogeneity in estimated impacts between discontinuities is informative.

Second, individual-level data on Cal Grant applicants exist beginning with the 1998 high school graduating cohort. Given that the two best administrative data sources for college-going National Student Clearinghouse (NSC) and 1098-T tax forms - only become available or reliable around this time period, these data are likely to serve as the best source for estimating aid's impacts on college-going and degree completion available in the United States. Population-based administrative tax return data also become available in 1999, allowing us to observe the take-up of Federal education tax credits in the years immediately following college application, and to track labor market, income, geographic mobility and family formation outcomes for these students for over fourteen years after applicants graduate from high school. ${ }^{3}$

Our work builds upon previous research by Kane (2003), which reports that the Cal Grant increased the likelihood that some students immediately enrolled in college. We improve on this earlier analysis by using a larger sample, a longer follow-up period, and a broader set of outcomes than previously available. In addition to the NSC and tax-based outcomes described above, we use federal student loan data to estimate the causal impact of the Cal Grant on other forms of federal financial aid.

In contrast to Kane (2003), we find that Cal Grant receipt has no meaningful effect on overall college attendance, in part due to high college-going rates among the population of applicants. However, at the GPA discontinuity we find noticeable effects on four-year college attendance

\footnotetext{
${ }^{3}$ All of our estimates are within the set of Cal Grant applicants. Using CSAC and US DOE data, we estimate that in 1999, 300,000 CA students graduated from high school. Of those 206,000 started the FAFSA and 110,000 applied for the Cal Grant. Cal Grant applicants cover more than one third of all graduating seniors and at least half of all college-bound seniors. Many graduating seniors who do not apply for the Cal Grant may be high-income or very low-GPA, suggesting we capture a large portion of the eligible applicant group.
} 
three and four years after high school graduation, likely because the Cal Grant increases persistence in college. We find that the Cal Grant significantly increases the probability of earning a bachelor's or graduate degree among this relatively lower-achieving population by 4.6 and 3.1 percentage points, respectively, which correspond to increases of roughly 10 and 27 percent over baseline. Point estimates suggest that Cal Grant raises earnings by 1.3 percentile points in the income distribution. This is an increase in earnings of 3-4 percent on average between ages 28 and 32 for those at the GPA discontinuity; however, the year-by-year estimates are quite imprecise. We do not detect any evidence of shifting of institution type following high school graduation, though alternate metrics of college quality suggest some upgrading as a result of the Cal Grant.

At the income discontinuity, we find shifts in the type of college a student attends: attendance at four-year private institutions increases by 5.6 percentage points, or roughly 30 percent, with an offsetting reduction in attendance rates at public two-year and four-year colleges and universities. These shifts are not accompanied with increases in school quality, as measured by graduation rates, median freshmen SAT scores, or "College Scorecard" average earnings, but are instead associated with increased tuition costs and reduced per student expenditures. For these students, point estimates suggest that the Cal Grant raises bachelor's degree completion and graduate degree completion by 3.0 percentage points, but these results are not statistically significant at conventional levels. Given the lack of institutional quality improvement, it is perhaps unsurprising that students at the income threshold display no impact of the Cal Grant on labor income, as measured by the sum of W-2 earnings and non-employee compensation, or adjusted gross income, between ages 28 and 32. We find suggestive evidence, however, that the program is successful at retaining individuals in-state in the longer run: students at the income discontinuity are 2.4 percentage points more likely to reside in California between these ages, on average, as a result of $\mathrm{Cal}$ Grant eligibility, although these results are sensitive to functional form assumptions.

We are among the first to examine impacts of merit aid on graduation and earnings. An important exception is Scott-Clayton \& Zafar, 2016, who study long-term impacts from West Virginia's PROMISE Scholarship. Their estimates from West Virginia's PROMISE, which uses merit-based eligibility criteria, are remarkably similar to those we find at the GPA threshold. Our 
results on graduate degree completion are similar in magnitude, however impacts on bachelor's degree completion for PROMISE scholarship recipients disappear over time. The earnings impacts are also of a similar magnitude with Scott-Clayton and Zafar (2016) finding a 7\% increase in earnings conditional on employment. In both cases, the earnings point estimates imply a very large and likely unrealistic return bachelor's degree attainment if effects work sole through degree completion. Our wide confidence intervals, however, include plausible returns. We suspect both that our point estimates overstate the true effect, and that earnings are impacted through channels other than degree receipt. The similarity in our estimates is notable because both populations straddle a merit-based eligibility threshold, but face different tuition implications and state school systems.

Our analyses inform the design of federal student aid policies, such as the American Opportunity Tax Credit, the suspended Hope Scholarship, and the Lifetime Learning Credit. Like the Cal Grant we study, these federal tax incentives for higher education are targeted to middle and higher-income students and provide financial support of a similar magnitude. ${ }^{4}$ Hoxby and Bulman (2016) find no impacts on college persistence from the Federal tax deduction for tuition and fees and suggest that timing and a lack of saliency could explain this result. We find meaningful effects from a similarly sized grant that uses a different mechanism to distribute aid. Importantly, the students who exhibit the largest longer-run earnings gains are those at the margin of GPA eligibility, a dimension that is not considered for these federal aid programs. In addition, our analyses inform the extent to which state-based aid programs impact the utilization of these and other sources of federal student aid, and their implications for long-run residency and earnings.

\section{Prior Literature}

The Human Capital model (e.g., Becker (1975)) suggests that individuals attend college when the expected benefits exceed the costs. Broadly, the goal of financial aid is to decrease the cost of college, especially among those who are liquidity-constrained. Aid can alter students' costbenefit calculus and induce additional students to enroll and persist. Indeed, the literature has documented positive effects of financial aid on attendance, persistence, and completion

\footnotetext{
${ }^{4}$ Unlike the Cal Grant and other state merit aid, the Federal subsidies do not target students based on high school or college achievement levels.
} 
(Bettinger, 2004; Bettinger, Long, Oreopoulos, \& Sanbonmatsu, 2012; Dynarski, 2003; Goldrick-Rab, Kelchen, Harris, \& Benson, 2016; Hoxby \& Turner, 2013; Kane, 2007; ScottClayton, 2011; Seftor \& Turner, 2002).

State-based merit-aid programs have multiple goals. First, by setting minimum academic thresholds for eligibility, they can incentivize additional academic effort at the high school level, a key predictor of college completion. A number of authors find that well-designed incentives can increase human capital accumulation in high school, potentially reduce state expenditures (e.g. by reducing time to degree), and accelerate students' entry into the labor market by one or more years (Domina, 2014; Henry \& Rubenstein, 2002; Pallais, 2009; Scott-Clayton, 2011).

Second, financial aid may directly affect college attendance and completion rates by reducing liquidity constraints, enabling students to travel farther to better institutions, or decreasing the need to work during college. There is significant evidence that state aid programs, whether through merit-based, need-based, or hybrid programs, can increase college attendance rates and completion rates, though results vary by state (Castleman \& Long, 2016; Cornwell, Mustard, \& Sridhar, 2006; Dynarski, 2000, 2004, 2008; Kane, 2003; Scott-Clayton, 2011; Singell \& Stone, 2002; Van Der Klaauw, 2002). ${ }^{5}$ Merit aid may also increase human capital accumulation if it produces additional effort or alters students' use of time by, for example, reducing the hours needed to work (DesJardins, McCall, Ott, \& Kim, 2010).

Finally, state-based programs aim to decrease "brain drain" by increasing the likelihood that topperforming students stay locally for college and enhance the stock of college-educated adults within the state. Unlike other forms of aid (e.g., Pell grants), state-based merit aid prioritizes specific institutions to keep the strongest students within state, which is particularly important as the market for high-performing students becomes increasingly national (Hoxby, 2009). In doing so, states hope to experience stronger economic growth, increase their tax base (Groen, 2004), and generate other benefits to individuals within their state (Oreopoulos \& Petronijevic, 2013). Evidence on whether aid induces students to attend college in-state is mixed, with research suggesting aid reduced out-migration in Georgia, with no equivalent effect in Tennessee (Cornwell et al., 2006; Pallais, 2009). The few available studies that examine long-term

\footnotetext{
${ }^{5}$ Only a few of papers on financial aid use a regression discontinuity design, with other work relying on differencein-difference estimation using large-scale nationally representative datasets (e.g., Dynarski (2008)).
} 
workforce outcomes rely on large panel data estimates and find that merit aid increased the likelihood that students resided within state through their early $30 \mathrm{~s}$, though estimated effects are generally small (Fitzpatrick \& Jones, 2012; Sjoquist \& Winters, 2013, 2014; Zhang \& Ness, 2010). However, the only study that relied on student-level microdata found no effect on longterm retention within Georgia (Sjoquist \& Winters, 2013).

The effects of state aid programs likely depend on program details, such as minimum academic thresholds, income limits, the size of the award, or the renewal requirements while in college (Domina, 2014; Long, 2004; Sjoquist \& Winters, 2014). As one example, during the time period studied in this paper, the Cal Grant provided larger tuition subsidies for private institutions than for public institutions; most states provide either equal or smaller tuition payments to private institutions (Domina, 2014). The heterogeneity in program design across states may partly explain the divergence in results found across the literature.

Along with Scott-Clayton and Zafar (2016), our study is among the first to construct a causal regression discontinuity estimate of financial-aid receipt on long-term mobility and employment outcomes. An additional strength is the timeframe currently available, which includes over a dozen years of follow up data to estimate academic and workforce outcomes. This longer timeframe is crucial for studying workforce outcomes, as individual earning profiles flatten significantly for individuals in their early 30s (Chetty, Hendren, Kline, \& Saez, 2014; Haider \& Solon, 2006), the age at which we can now observe these students. An additional benefit of using individual-level data is that we estimate returns to aid, as measured by both college completion and administrative earnings records. We compare these returns to the monetary amount spent on each student. Our results shed light on whether financial aid expenditures, which have totaled billions of dollars over the last few decades, are producing their intended effects.

\section{Institutional Details, Research Design and Sample Construction}

\section{A. Overview of the Cal Grant Program}

The Cal Grant program is a need- and merit-based financial aid program administered by the California Student Aid Commission (CSAC). CSAC offers several awards that vary in their target populations and benefits. We focus on what is referred to as "Cal Grant A" for the high school graduating cohorts who enter college from 1998-99 through 2000-01. This award is a 
"first-dollar" scholarship - meaning that the award is allocated prior to other forms of financial aid, such as the Pell Grant - and provides four years of full-time tuition assistance. Tuition at California State University (CSU) or the University of California (UC) was approximately $\$ 1,500$ and $\$ 3,500$, respectively, in the late 1990s. In addition, students could use Cal Grant A to attend any in-state private institution, with the award subsidizing between $\$ 9,000$ and $\$ 9,700$ depending on the year. ${ }^{6}$ Students could not use Cal Grant A to attend a community college, but the award could be put on hold for up to two years for students who wished to delay four-year enrollment. $^{7}$

Baseline eligibility for the $\mathrm{Cal}$ Grant requires an applicant to be a California resident (either a U.S. citizen, permanent resident, or eligible non-citizen), have no defaults on federal loans, and have not previously earned a bachelor's degree. Students must have submitted the FAFSA and a GPA verification form, which was to be completed by the high school attended, by March $2^{\text {nd }}$. The GPA verification form is completed by the high school and sent directly to CSAC. In addition, applicants are disqualified if their assets (excluding housing value and retirement funds) exceed specific limits, though this impacts few students. ${ }^{9}$ Our sample uses only the set of people who applied for a Cal Grant. We estimate that this sample represents approximately $50 \%$ of college-bound seniors in California, and hence a large group of considerable interest (see footnote 3).

The primary form of eligibility for recent high school graduates depends on a student meeting a minimum GPA requirement and being below specific income thresholds. Importantly, these rules fluctuated because of changes in annual funding during our analysis period, resulting in several plausibly exogenous discontinuities in eligibility. First, the income limits varied from year to year using cost of living increases based on the California Constitution. These limits would have been virtually impossible for families to calculate and anticipate. In 1998, the income limits ranged from $\$ 53,100$ for families of three or fewer to $\$ 67,000$ for families of six or larger, and in

\footnotetext{
${ }^{6}$ Subsidy amounts were $\$ 9,036, \$ 9,420$, and $\$ 9,708$, for the 1998,1999 , and 2000 cohorts, respectively.

${ }^{7}$ California community college tuition was $\$ 11$ per unit in 1999-2000, which was the lowest rate in the nation.

${ }^{8}$ In practice, CSAC included all applications received by March $12^{\text {th }}$, to allow for potential complications in the mail.

${ }^{9}$ During our sample period, dependent students and independent students with dependents were disqualified if they had assets (excluding housing value) between $\$ 42,000$ and $\$ 49,600$ (depending on the year). Independent students without dependents (other than a spouse) were required to have assets below $\$ 20,000$ and $\$ 25,110$ (depending on the year).
} 
2000 ranged from $\$ 59,000$ to $\$ 74,100$ for the same categories. Second, income-eligible applicants were ranked by GPA in descending order and were offered awards until funding was exhausted. This produced a GPA eligibility cutoff that was unknown to applicants $a$ priori. The resulting GPA cutoffs were 3.15, 3.09 and 2.95 for 1998, 1999 and 2000, respectively. Figure 1 shows how the GPA cutoff varied by year until 2001-02 when it was fixed (and publicly known) at 3.0.

We remove a number of extremely low-income students from our sample who were eligible for an alternative financial aid package. Specifically, there is a second income limit - about half the size of the maximum income allowed - below which "low-income" students are entered into a separate competition that produces a point total that makes them eligible for an alternate grant award, Cal Grant B. ${ }^{10}$ For these point-eligible students, crossing the GPA threshold has no meaningful impact on award eligibility.

Simply meeting the income or GPA requirements is a necessary but not sufficient condition for receiving the $\mathrm{Cal}$ Grant. In addition, a student or their family must also have sufficient "unmet financial need," which is calculated based on a student's potential expenses and expected family contributions. ${ }^{11}$ We ignore this distinction and present reduced form results that include these students because of the difficulty in calculating CSAC's unmet need and the potential endogeneity of student expenses that are directly related to the types of institutions they wish to attend.

\footnotetext{
${ }^{10} \mathrm{Cal}$ Grant B offers similar tuition payments to Cal Grant A though for three years rather than four, though additionally offers a subsistence (cash) payment of approximately $\$ 1,500$ per year. At the time of our study, points were earned through higher GPA and measures of disadvantage, including lower family income, and the point threshold varied from year to year. For the sample of students who meet the points requirement, we find that crossing the GPA threshold has a precisely estimated null effect on award utilization, thus meriting their exclusion. Although this point system offers the promise of an additional RD analysis, we do not study it here due to the relatively small sample size, as well as other technical details specific to how Cal Grant B was handled in those years. Eligibility for Cal Grant B changed in 2001; at that point, many more students become eligible for Cal Grant $\mathrm{B}$ and could choose between the two awards, but that is not the case in our sample period.

${ }^{11}$ CSAC's "unmet need" requirement is different than what is generally reported from the FAFSA. To calculate whether a student has unmet need, a Cost of Attendance (COA) is assigned to each of the up to six schools a student has listed on their FAFSA. CSAC then subtracts a student's Expected Family Contribution (EFC) from each school's COA to create the unmet need value. For a student to be Cal Grant A eligible, a student must have unmet need equal to the maximum Cal Grant award amount available for that institution plus $\$ 1500$, rather than simply having a positive COA less EFC value.
} 
California expanded the Cal Grant program significantly in 2001-02, changing how awards were allocated (though the monetary value of the awards remained constant). Beginning in this year, the GPA threshold for Cal Grant A was set at 3.0 in perpetuity, and so could be known by applicants a priori. In addition, family income thresholds were more widely publicized at this time. We find evidence that applicants were likely aware of the eligibility thresholds beginning in these years. ${ }^{12}$ Thus, we restrict our analysis to applicants prior to the 2001-02 academic year.

\section{B. Research Design}

Because the Cal Grant is allocated by a combination of academic achievement and financial need, simple comparisons of outcomes between financial aid recipients and non-recipients will likely produce biased estimates of the impact of financial aid; family background and academic preparation are correlated with the likelihood of receiving aid, the amount of aid received, and the likelihood of attending and graduating from college. To estimate the causal impact of the Cal Grant on student outcomes, we exploit the GPA and income eligibility cutoffs using a regression discontinuity (RD) design, where we compare students who just qualified for a grant to similar students who were just ineligible by utilizing Equation 1:

$$
Y_{i t}=\beta_{0}+\beta_{1} * \text { Distance }_{i}+\beta_{2} * C G_{i}+\beta_{3} * C G_{i} * \text { Distance }_{i}+X_{i}+\varepsilon_{i t}
$$

In this regression, $Y_{i t}$ is an outcome of interest (such as college enrollment or earnings) for student $i$ in year $t, C G_{i}$ is a variable that equals one if a student is Cal Grant eligible, and Distance $_{i}$ is a continuous running variable that determines assignment to treatment, centered at the application year-specific eligibility cutoff. We show a linear specification here, but Distance $_{i}$ can take a flexible functional form that includes higher-order polynomials. The vector $X_{i}$ contains the following baseline observable characteristics: student age, citizenship status, parent's marital status, and parental education. All regressions also include family size-by-year fixed effects (where family size varies from two to "six or more") to account for the varying income-eligibility cutoffs. The parameter of interest, $\beta_{2}$, represents the intent-to-treat parameter or the causal effect of the offer of the Cal Grant award on our outcomes of interest. In practice, the inclusion of

\footnotetext{
${ }^{12}$ Correspondence with CSAC personnel indicates that 2002 was the first year that CSAC's "Fund Your Future Workbook" published the exact income limits. We find clear evidence of violations in the density of applicants around the income cutoff in later years, though the violation appears to be that ineligible families simply did not apply, rather than altered their income.
} 
observable characteristics $X_{i}$ is optional; their inclusion does not result in significant changes to our estimates of $\beta_{2}$, but improves precision for some of our outcomes, particularly for earnings. Standard errors are clustered by standardized GPA when exploiting the GPA cutoff because the assignment to treatment variable is discrete (Lee and Card 2008). We report heteroscedasticity robust standard errors for regressions using the income cutoff.

We run these regressions for the GPA cutoff and the income cutoff separately. The GPA threshold compares income-eligible students just above and below the GPA eligibility criteria who were not eligible for Cal Grant B. The income threshold compares GPA-eligible students just above and below the maximum income eligibility limits. In both of these cases, students who meet the respective GPA or income requirement are eligible for Cal Grant A, provided that they satisfy the "unmet need" requirement. Students who do not meet the cutoff are not immediately eligible for any $\mathrm{Cal}$ Grant award. We describe the differences in the samples around these two distinct cutoffs in the next section.

We also run the following instrumental variables (IV) regressions:

$$
\begin{gathered}
\text { Award }_{i t}=\alpha_{0}+\alpha_{1} * \text { Distance }_{i t}+\alpha_{2} * C G_{i t}+\alpha_{3} * C G_{i t} * \text { Distance }_{i t}+X_{i t}+\varepsilon_{i t} \\
Y_{i t}=\beta_{0}+\beta_{1} * \text { Distance }_{i t}+\beta_{2} * \widehat{\text { Awar }} d_{i t}+\beta_{3} * C G_{i t} * \text { Distance }_{i t}+X_{i t}+\varepsilon_{i t}
\end{gathered}
$$

The first-stage regression predicts the likelihood that students utilize the Cal Grant $\left(\operatorname{Award}_{i t}\right)$ at the margin. We use these predicted values to estimate a Local Average Treatment Effect (LATE) for those induced to use the Cal Grant. This parameter estimates the effect for those who take up the treatment, as compared to those who were unlikely to use the treatment irrespective of their assignment.

There are several reasons why an applicant who satisfied the GPA and income eligibility requirements may not be awarded a grant. Some students may choose to not attend college or attend an out-of-state institution. Other students may be denied an award based on the unmet need requirement, which we are unable to precisely estimate. In addition, Cal Grant A cannot be used at a community college, which is a commonly attended institution for many students at the margins of GPA eligibility. Students who are initially ineligible for the Cal Grant may later receive an award, generally via one of two ways. First, students initially apply for the award in 
$12^{\text {th }}$ grade with their cumulative $10^{\text {th }}$ and $11^{\text {th }}$ grade GPA. If their $12^{\text {th }}$ grade GPA pushes them above the required margin, they can apply in the subsequent year with their new cumulative GPA. Second, CSAC began to offer an alternative "Competitive" award for older, nontraditional students who are two or more years out of high school, and some initially ineligible students may later qualify for this financially equivalent award.

\section{Data and Sample Construction}

Our sample consists of retrospective data on all students in California who were minimally eligible for the Cal Grant program, and submitted both a FAFSA and GPA verification form to CSAC during their final year of high school, which occurred between 1998 and 2000. Data on these hundreds of thousands of high school graduates who applied for the Cal Grant are provided by CSAC.

We gather outcome data from several sources. One source of data on college enrollment and degree completion comes from the National Student Clearinghouse (NSC). The NSC data cover about 94 percent of all college enrollments and have significant degree completion records. NSC data provide information on all institutions that a student attended, dates attended, whether the student transferred, whether degrees were conferred, the types of institutions attended, the intensity of enrollment, and the length of time required for degree completion. ${ }^{13}$ One potential concern is that low NSC coverage rates in the late 1990s may bias results. ${ }^{14}$ We address this issue by identifying schools with low NSC coverage rates and focusing our NSC analysis on students who only list well-covered schools on the FAFSA. ${ }^{15}$

\footnotetext{
${ }^{13} \mathrm{NSC}$ data is increasingly used for tracking postsecondary outcomes, but is subject to bias due to missing data and errors in matching that rely on students' names and birthdates (Dynarski, Hemelt, \& Hyman, 2015). In general, we find that NSC data provide similar estimates of college-going as 1098-T tax forms.

${ }^{14}$ California's NSC institutional coverage rate was roughly 59\% in 1998 (Dynarski et al., 2015), though four-year public and private coverage rates were $93 \%$ and $71 \%$ in 1998 , respectively, and the state's overall coverage rate was $93 \%$ by 2001 , when students would first be earning their degrees. If we believe the aid is likely to push students towards more expensive institutions then we may underestimate shifts away from community colleges, which offered no bachelor's degrees at the time, and underestimate shifts towards private institutions; depending on the quality difference between the four-year public and specific private institutions, we could be slightly overestimating or underestimating true bachelor degree completion effects.

15 There are two main methods for identifying low coverage rates. The first utilizes information provided by the NSC which identifies non-participating schools and schools with high FERPA block rates. A second, specific to our dataset, is to examine all students who received a Cal Grant payment, which we know to be highly accurate, calculate the percentage of students of payees who do not show up as attending that school in the NSC data, and assign this value as an "incompleteness" rate to the school. Both methods produce similar results. When comparing
} 
As an alternative source of information on college attendance, we collect information returns that colleges submit to the IRS to report "qualified educational expenses" in a given year, Form 1098-T. These are drawn from the population-based, administrative tax records for each student, available beginning in 1999. We use the 1098-T data as our primary source for measuring college attendance, as these data do not suffer from the missing data problems of the NSC. We match both NSC and 1098-T data to the Integrated Postsecondary Education Data System (IPEDS) to identify the type of institution that a student attends. We also collect several institutional characteristics: school size, tuition, $150 \%$ time to graduation, SAT score at the $25^{\text {th }}$ and $75^{\text {th }}$ percentiles, and expenditures per full-time equivalent (total, and across spending categories).

For each Cal Grant applicant, we construct information on federal student loans and Pell Grant awards that they have received. These data come from the National Student Loan Data System (NSLDS), a comprehensive national database of information on federal financial aid. We also collect information on the federal education tax credits that are claimed by the tax filing unit associated with the Cal Grant applicant beginning in 1999. To construct this data, we identify the tax return that includes a Cal Grant applicant in each tax year, which may be the applicant's own return, and collect information on the American Opportunity Tax Credit and Lifetime Learning Credit. $^{16}$

Our primary measure of college attendance identifies whether a student is enrolled at a postsecondary institution at any point within four years of Cal Grant application, rather than identifying the more typical "immediate postsecondary attendance." We choose this method for two primary reasons: (1) somewhat lower coverage rates for NSC data in their earliest years of implementation in the late 1990s, that improves rapidly over time; and (2) the reliance of 1098-T data on calendar year enrollment, rather than academic year, that could lead to attendance overestimates (for high school students taking college courses who do not continue their

results on our NSC subset and the full population, we find that degree completion impacts are underestimated at the GPA threshold, consistent with the idea that non-reporting underestimates positive impacts. We find degree impacts are likely overestimated at the income threshold, as students switch into private colleges that may be less likely to report data.

${ }^{16}$ Data on the link between tax filers and dependents are incomplete prior to 2001 . We fill in missing observations by assuming that the modal tax filer that claims the applicant on a tax return between 1999 and 2006 is the tax filer that claims the applicant in the years of missing data problems. We also collect information on the tuition and fee deduction, but it is rarely utilized by this population and so do not study it here. 
education) or underestimates (if students attend college in the fall after high school graduation but quickly drop out). Alternate methods produce similar results, and analyses focused on school quality identify the first college attended. We similarly construct enrollment measures for specific postsecondary sectors within California schools.

Labor market, income, demographics and mobility data are drawn from administrative, population-level U.S. federal tax filings. For each Cal Grant applicant, we construct a panel of tax returns spanning tax years 1999 through 2013, supplemented with several information returns filed with the IRS by third parties. Tax return data provide information on household-level wage income and adjusted gross income (AGI). We additionally collect the limited demographic information available on a tax return: marital status, number of children, and state of residence. We compute a household size-adjusted measure of AGI, which divides AGI by the square root of the number of individuals in the tax unit (i.e., the primary filer plus secondary and dependents), to account for income level differences due to differences in family structures.

Because tax returns provide data conditional on filing a tax return, and because earnings are reported at the household level when married filing jointly, we also consider individual-level earnings data. These data come from Form W-2, the information return on wage and salary income, and Form 1099-MISC, the information return on non-employee compensation, both filed by businesses to the IRS. We compute labor income as the sum of earnings on these two tax forms. We account for outliers in these unedited data by winsorizing income variables at the $99^{\text {th }}$ percentile. We translate labor income into percentiles in the income distribution using data from Table 6 of Chetty et al. (2016), which provides the correspondence between child income and income percentiles by child birth cohort.

In our baseline analysis, we use a 0.3 point bandwidth around the GPA eligibility cutoff, and a $\$ 10,000$ bandwidth around the income eligibility cutoff, as suggested by cross-validation and Imbens and Kalyanaram (2012) optimal bandwidth techniques. ${ }^{17}$ Table 1 shows summary statistics for the sample of 31,500 applicants who are within 0.3 points of the GPA discontinuity

\footnotetext{
${ }^{17}$ In general, the optimal bandwidth varies by both validation technique and outcome chosen (e.g., first-stage award utilization, degree completion). We present results using a range of bandwidths, including those using the Calonico et al (2014) optimal bandwidth selection, in appendix tables. We note cases where bandwidth choice affects the results.
} 
and 18,097 applicants who are within $\$ 10,000$ of the income discontinuity. Our two analytic samples are quite different from applicants in general and from each other because we focus on students near the eligibility thresholds. At the GPA discontinuity, 56 percent of applicants are female, and 86 percent are U.S. citizens. Forty-four percent initially attended a California public four-year institution, with an additional 9 percent initially attending some form of private college. Mean family income was $\$ 35,100$ at the time of application. At some point within 10 to 14 years after applying, 89 percent of the sample is living in California, 52 percent are married, and 46 percent have children. Students at the income discontinuity have higher family incomes and high school GPA, are more likely to attend private colleges or four-year institutions, and are have average incomes between 10 and 14 years after initial application. They were also more likely to be married but less likely to have children. These differences potentially shed light on why results might vary across the two analytic samples.

\section{Validation of the RD Design}

Before turning to our main results, we provide evidence that the discontinuities in award eligibility can serve to produce unbiased estimates of the effects of state-based aid. The three key assumptions for the validity of an RD design are: (1) that the predicted discontinuity creates a large change in assignment to treatment as a function of the running variable; (2) any observed differences in the neighborhood of the discontinuity occur only as a result of differences in the running variables; and (3) that there is no evidence of manipulation in assignment to treatment near the discontinuity. We address each of these assumptions in turn.

Figure 2 shows that Cal Grant A utilization rates vary discretely at each eligibility cutoff. We pool our data across all years and center the running variable at zero for each year-specific threshold. The left panel of Figure 2 shows that the GPA threshold predicts close to a 40 percentage point increase in ever receiving a Cal Grant payment. At the bottom of Table 2 we provide corresponding point estimates for Cal Grant receipt, which shows that total CSAC payments increases by roughly $\$ 4,300$ for the average student at the GPA cutoff. ${ }^{18}$ There is a

\footnotetext{
18 There are some students below the GPA cutoff who received Cal Grant awards. This is primarily due to three reasons: students who applied in their senior year could resubmit the following year by incorporating their $12^{\text {th }}$ grade GPA; CSAC's Competitive award that became available in 2002 and was applicable for students more than one year removed from high school; we were able to eliminate some but not all point-eligible students at the "low-income"
} 
similar shift in Cal Grant utilization at the income threshold shown in the right panel of Figure 2. In this and all future income-based figures, we multiply the running variable by -1 so that positive (negative) values correspond to Cal Grant eligibility (ineligibility). The bottom panel of Table 2 shows that total payments received are significantly larger at the income threshold, at roughly $\$ 8,100$ per award offer. This larger amount derives in large part from students at this threshold attending more expensive UC and private schools. IV estimates suggest that the shift in average full payment for students who utilized the Cal Grant payments award were close to $\$ 11,200$ and $\$ 19,300$ at the GPA and income thresholds, respectively.

Next, we examine whether factors that are correlated with student outcomes change discontinuously at the thresholds that determine assignment to treatment. For each observable characteristic, $X_{i t}$, we run the following regression:

(3) $X_{i}=\beta_{0}+\beta_{1} *$ Distance $_{i}+\beta_{2} * C G_{i}+\beta_{3} * C G_{i} *$ Distance $_{i}+\varepsilon_{i}$

In Appendix Table A2, we present estimates for $\beta_{2}$, which captures the difference in covariates between those just above and just below the eligibility threshold. These results provide evidence of continuity across the thresholds. Importantly, we find that GPA is smooth at the income discontinuity, and vice versa, suggesting there is no systematic sorting of eligible students. We find no imbalance in the likelihood of being female, a U.S. citizen, or having married parents at the threshold. Appendix Figures A1 and A2 provides corresponding graphical evidence at the GPA and Income thresholds, respectively.

Finally, if students were able to manipulate assignment to treatment, then observable or unobservable characteristics of applicants may differ around the cutoff. In principle, there is limited scope for manipulation because it would have been difficult, if not impossible, to know the eligibility cutoffs a priori. Nevertheless, we provide evidence that there is no manipulation in the years of our analysis. Directly examining manipulation for the GPA threshold is difficult for two reasons. First, the McCrary test, which relies on non-parametric estimation, is problematic for discrete distributions (McCrary, 2008). Second, Cal Grant applicants who are high school seniors utilize their unadjusted $10^{\text {th }}$ and $11^{\text {th }}$ grade GPA, leading to a "lumpy" distribution.

GPA threshold. In all cases, we keep only the earliest Cal Grant application for each student, so thresholds are exogenous. 
Appendix Figure A3 shows the exact distributions for GPA in each year. Although the number of applicants bunches at specific GPA points, especially at 3.0, this lumping is equivalent across the three years, with little observational evidence that students are sorting differentially with respect to the cutoff. An overlay of the three years shows that distributions are similar, even though the GPA thresholds changed markedly between years. At the income cutoff, we check against the possibility of manipulation using the traditional McCrary density test (McCrary, 2008). Appendix Figure A4 shows that the distributions are smooth with no evidence of manipulation around income thresholds in the pre-expansion years. ${ }^{19}$

\section{Results}

In this section, we present results in three broad outcome categories: (1) college attendance and attainment; (2) longer-run earnings, family formation, and mobility outcomes; and (3) school quality and college financing. We examine effects at the GPA and income discontinuities separately. Importantly, the effects of Cal Grant eligibility (equation 1) and of Cal Grant utilization (equation 2) are identified using somewhat different groups of students depending on which discontinuity is being utilized. The students at the margin of the GPA threshold are, on average, of lower income and entering college with weaker academic preparation than students at the income threshold. Scatter plots showing how dependent variables vary across the yearspecific eligibility thresholds appear in Appendix 3, unless presented here.

\section{A. College Attendance and Completion}

Table 2 presents results from estimating equation (1) on our educational attendance outcomes using linear slopes with rectangular kernels. Because college attendance outcomes using 1098-T data produce roughly similar results but on a more representative sample, we place NSC-based attendance results in Appendix Table A3. ${ }^{20}$ We report both the reduced-form and instrumental variable results. In Appendix Tables A4, A5, and A6, we show that our results are robust to several factors: (1) alternate bandwidths and the Calonico, et. al (2014) optimal bandwidths; (2) covariates and functional forms; and (3) triangular kernels, respectively. In the top panel of

\footnotetext{
19 The McCrary test at the income cutoff provides an estimate of 0.0033 with a standard error of 0.0365 (t-stat $=0.09)$ for the NSC sample and 0.0194 with a standard error of $0.0382(\mathrm{t}$-stat $=0.51)$ for the Treasury sample.

${ }^{20}$ Although attendance results using NSC data are relatively similar in magnitude as results based on 1098-T data, in some cases they lack statistical significant due to the smaller sample sizes that result from focusing on the subsample of students interested in colleges well-covered by NSC data.
} 
Appendix Table A11, we present results for low-income and middle-income students at the GPA threshold separately and high-GPA and low-GPA students at the income threshold separately. In Appendix Table A12, we present results split by student gender and application year.

The first two rows of Table 2 show results on degree attainment, with corresponding graphical results presented in Figure 3. At the GPA threshold, reduced-form estimates show that the likelihood that students achieved a bachelor's degree increased by 4.6 percentage points. The IV results suggest a 14.6 percentage point increase in bachelor's degree completion. Undergraduate aid has additional long-term educational impacts, raising graduate degree completion at the GPA discontinuity by 3.1 and 9.7 percentage points in the reduced form and IV estimations, respectively. Although we do not show results here, the increased graduate degree completion at the GPA margin also occurs almost exclusively within California colleges rather than out of state.

At the income threshold, we find roughly similar results on bachelor's degree completion, with reduced form and IV estimates showing a 3.0 and 7.6 percentage point increase, respectively. Similar to the GPA threshold, we find positive OLS and IV effects on graduate degree completion of 3.0 and 7.5 percentage points, respectively. None of these effects are statistically significant at the 5 percent level, as regressions are restricted to students who only favor NSCcovered institutions, significantly reducing our power.

Next, we examine the effect of financial aid on traditional measures of college attendance. Cal Grant eligibility had no meaningful impact on overall attendance at a postsecondary institution at either the GPA or the income thresholds (row 3). The immediate college-going rates for students at the GPA and income thresholds are 83 and 93 percent, respectively (Table 1), with eventual college-going rates of well over 90 percent for both groups. These attendance results differ from those reported in Kane (2003), and we discuss the likely sources of these differences in Appendix 1.

At the GPA discontinuity, we find few shifts in the institution sector that students attend (Table 2, column 2, rows 4 to 6 ). These students are predominately choosing among very few options, generally consisting of a community college or a lower-tier four-year institution (e.g., California State University). Although there is no initial impact on attendance or institution sector, a 
number of results suggest that the degree completion increase we document above is in part due to increased persistence among those who would have attended college in the absence of aid. Specifically, Cal Grant does not impact the likelihood of initially enrolling in a four-year institution but it does impact the likelihood of still being in a four-year institution three and four years after high school graduation (Appendix Figure A6.).

In contrast, we find large shifts in the sector of college attendance at the income threshold (Table 2 columns 5-6, rows 3-6 and Figure 4). Cal Grant eligibility leads to a statistically significant 5.6 percentage point increase in private school attendance (row 6), coupled with significant decreases in four-year public and community college attendance. Because students can enroll in more than one sector within four years of application, these RD estimates need not sum to one across sectors. Appendix Figure A7 shows that the effects for four-year public and private college attendance are fairly stable within the 1 to 4 years after Cal Grant application. In results not shown, we find that the negative effect on attending a community college is concentrated in the first two years after application. ${ }^{21}$

\section{B. Long Run Earnings and Mobility}

We now turn to Cal Grant's impacts on earnings, marital status, tax filing status, and likelihood of living in California. Main results are in Table 3, with robustness tests in Appendix Table A7, A8, and A9, which match Appendix Tables A4, A5, and A6, respectively. In the bottom panel of Appendix Table A11, we present results for low-income and middle-income students at the GPA threshold separately and high-GPA and low-GPA students at the income threshold separately. In Appendix Table A13, we present results split by student gender and application year. For all outcomes, we run stacked regressions for 10 through 14 years after the student applied for a Cal Grant, when most applicants would be between 28 and 32 years old. Standard errors in these specifications are clustered at the individual level. We first test whether Cal Grant eligibility impacts the likelihood that a student files a tax return (row 1). We find economically small and statistically insignificant differences in filing propensities at both discontinuities. In Appendix Figure A8, we show year-by-year point estimates of the likelihood of filing a return. In all cases,

${ }^{21}$ Results in Appendix Table A12 show educational impacts disaggregated by student sex and application year. Although there is suggestive evidence for larger impacts for some outcomes and groups (e.g., females at the GPA threshold may be more likely to earn bachelor's degrees than males), most of the results are fairly similar across groups. 
the effects on filing a return are statistically insignificant, with the largest values approximately 1 percentage point. At the GPA discontinuity, our estimated effect of Cal Grant on tax filing is 0.3 percent (relative to a mean of $93 \%$ ) and we can reject impacts larger than 1.3 percentage points.

We find evidence that individual earnings increase at the GPA threshold, though estimates are noisy. Cal Grant eligible students rise by 1.33 percentile points in the income distribution for earners in their cohort around age 30, although this result is not particularly robust to alternative bandwidths. When we use log earnings as the dependent variable, we estimate that Cal Grant eligibility increases earnings by roughly 5.4 percent. This result is presented graphically in the left panel of Figure 5. This 1.33 percentile point earnings increase translates into about a $\$ 1,800$ increase in earnings, or about $4.9 \%$ of earnings at the mean of $\$ 37,000$. Results using earnings rank (percentile) differ somewhat from results using the log of earnings because the latter excludes individuals with zero earnings and imposes a different functional form. There is also a positive impact on the $\log$ of household-size adjusted AGI, with an increase of 3.2 percent; however, this effect is not statistically significant. We examine the wage income effects at the GPA threshold for each year post-application, and there is additional evidence suggesting impacts on earnings (Figure 6). The point estimates for years 8-14 are all positive and trending upward, with statistically significant effects in years 10 through 14 . We find no impacts on labor income and AGI at the income threshold (Appendix Figure A9). In particular, the estimated effects on the log of household-size adjusted AGI and the log of labor income averaged over years 10 through 14 are both near zero. The point estimates are negative, and at some alternative bandwidths, the negative effects are statistically significant (Appendix Table A7). Although we emphasize that our estimates our imprecise, the lack of positive earnings effects is consistent with the fact that students at the income discontinuity are being induced into attending moderately selective or non-selective four-year private colleges, largely at the expense of fouryear public institutions. We return to this issue of impacts on school quality in the next section.

In the fifth row of Table 3, we examine impacts of Cal Grant eligibility on geographic mobility. At the income discontinuity, we see a 2.4 percentage point increase in the likelihood of remaining in California, with the graphical result presented in the right panel of Figure 5, and year-by-year results plotted in Figure 7. Results on residency are particularly relevant, as these students are the highest earners in our sample, and so might provide California the greatest 
marginal return in increased revenues. This result is sensitive to functional form assumptions and bandwidth selection; in Appendix Table A7 this effect is only statistically significant at the 5 percent level in 4 of 7 specifications, with most specifications varying between 1.0 and 2.4 percentage points. At the GPA discontinuity, we do not find any impact of the Cal Grant on remaining within California 10 to 14 years after award receipt; year-by-year results are plotted in Appendix Figure A10. Although this may be evidence against merit aid impacting outmigration, it also suggests that the additional graduates produced by the award are as likely to remain within the state as other graduates.

The last two rows of Table 3 examine family formation by estimating whether aid eligibility impacts whether students are married or have kids in their late 20 s to early 30 s. Our point estimates generally indicate that there was no significant impact of the Cal Grant on any of these household formation outcomes. The exception is a significant 2.3 percentage point reduction in having children at the GPA threshold. These results do not appear to be robust, however, ranging from less than -0.0001 to -2.3 percentage points across bandwidths and model specification (Appendix Table A7), and are rarely statistically significant. ${ }^{22}$

\section{School Quality and Financing of College Costs}

The previous subsections suggest distinct impacts of the Cal Grant on the two subpopulations that we examine: students at the lower bound of GPA eligibility see improvements in college degree attainment and longer-run earnings, while eligible applicants who are the most financially well-off shift from attending public institutions to private institutions, with a corresponding increase in college degree attainment but no impact on longer-run earnings. To further understand these different experiences, we first examine how Cal Grant eligibility impacts traditional measures of college environment and quality in the top panel of Table 4. All college

\footnotetext{
${ }^{22}$ Results in Appendix Table A13 show impacts on long-run income and demographic outcomes disaggregated by student sex and application year. There is suggestive evidence for larger impacts for some outcomes and groups (e.g., there is a larger estimated earnings gain for males at the GPA threshold). At the income threshold, we find a positive effect of Cal Grant eligibility on being married nad having children for men, and a negative effect for women.
} 
characteristics measures are derived from IPEDS data on institutional characteristics based on the first postsecondary institution attended. ${ }^{23}$

Although we find no large shifts in the sector of postsecondary attendance at the GPA threshold, there is suggestive evidence of some movement towards higher-quality colleges, with small increases in graduation rates, median freshmen SAT scores, and research expenditures per fulltime equivalent. Changes in the measures of postsecondary environment are much larger at the income threshold, as the shift towards private colleges results in students attending smaller but more expensive colleges. Interestingly, these changes do not correspond to increases in measures of school quality, such as time to graduation or median freshmen SAT score, and are associated with lower per student expenditures, particularly in the areas of academic support and research. ${ }^{24}$ These findings suggest that students at the income threshold use the Cal Grant to attend more expensive private institutions that offer no discernable upgrades in school quality.

To further explore the relationship between sectoral shifts and student outcomes, we test whether degree completion rates vary by self-reported college type preferences. We disaggregate applicants into three groups based on the types of schools that they listed on their FAFSA form: (1) students who listed only four-year public schools; (2) students who listed any private schools; and (3) the remainder of students, including the majority of students who listed a community college. ${ }^{25}$ Appendix Table A10 presents results on the type of institution ultimately attended and degree attainment for each group separately. Although the estimates are often imprecise, the results suggest that bachelor's degree completion (column 4) is not restricted to any specific group. In particular, students who list private colleges on the FAFSA exhibit the biggest shifts in the sector of postsecondary enrollment, yet their degree completion rates are not consistently larger than any other group. For example, students at the GPA margin who list a private college on the FAFSA are 2.3 percentage points more likely to attend a private college but only 0.3

\footnotetext{
${ }^{23}$ We apply estimates from 2001 IPEDS data to each year in our sample as most values are consistent across years and there is a higher proportion of missing data in earlier IPEDS years. The graduation rate is the percent of students completing a degree within $150 \%$ of normal time, irrespective of degree type (i.e., associate's degree completion at two-year schools and bachelor's degree completion at four-year schools).

${ }^{24} \mathrm{We}$ also examined whether Cal Grant recipients attend colleges with different mean earnings as measured by the "College Scorecard." We don't find any evidence of differences in Scorecard earnings for Cal Grant recipients. For instance, at the GPA discontinuity, Cal Grant recipients attend colleges with Scorecard earnings that are $\$ 354$ per year higher (measured 10 years after college entry). At the income discontinuity the effect is $\$ 54$ per year.

${ }^{25} \mathrm{We}$ lose about $1.5 \%$ of the sample due to missing FAFSA preferences or unidentified schools.
} 
percentage points more likely to earn a bachelor's degree, whereas students who only list fouryear public colleges are close to 8 percentage points more likely to earn a bachelor's degree. For students at the income threshold, showing some preference for a private institution is predictive of attending one, but this does not translate into significantly higher degree completion effects. The point estimates suggest that degree completion effects are largest for this group, so while there may be positive impacts of private college attendance, they do not singularly drive the observed increases in degree completion. Appendix Table A11 shows similar results that disaggregate the sample into high- and low-GPA at the income threshold, finding that bachelor's degree completion shifts more for low-GPA students, even though both groups exhibit large shifts towards private schools.

An implication of the sectoral shifts that result from the Cal Grant is that financial aid might not lower the total cost of college that students face. Both the shift into more expensive institutions at the income threshold and increased postsecondary persistence at the GPA threshold may result in higher expenditures. The bottom panel of Table 4 examines whether there are other sources of financial relief that are utilized, namely federal loans and grants received, and Federal education tax credits taken. Although results are noisy, there are no decreases in total student loans, with statistically insignificant but positive increases in observed loan amounts, particularly among students at the income threshold. Our lack of an impact on loans contrasts with Chapman (2015), who looks across merit aid programs in thirteen states and finds that merit aid reduces total loans by about $\$ 6,000$ total. However, our findings are consistent with Scott-Clayton and Zafar (2016), who look specifically at West Virginia's PROMISE scholarship and find no increase in total loans when undergraduate and graduate loans are summed together. At the GPA cutoff, we find no changes in Pell Grant dollars received; the "first-dollar" structure of the Cal Grant program should theoretically leave Pell Grants unaffected, and there is no reason for students to forgo this aid that can help pay for room and board or other expenses. At the income cutoff, Cal Grant eligibility lowers Pell use by 1.1 percent which is statistically significant at the 10 percent level. ${ }^{26}$ Lastly, we find that there is no impact on the take-up of Federal education tax credits or the amount of credits that are claimed in years 1 through 4 after application.

\footnotetext{
${ }^{26}$ The coefficient at the GPA cutoff is similar in magnitude. But at the GPA cutoff the estimate is both noisy and a much smaller when scaled by average Pell use at the GPA cutoff.
} 
Overall, the large shifts in the sector of postsecondary enrollment at the income threshold are not necessarily indicative of improvements in postsecondary environment. The types of private institutions attended at this threshold are generally mid-tier, denominational schools, rather than California's top-ranked private institutions. As a result, these shifts have unclear impacts on labor force outcomes. For high-performing students, these shifts could increase degree completion while simultaneously decreasing human capital investment. ${ }^{27}$ In contrast, bachelor's degree completion for students at the GPA threshold appears to represent an unambiguously positive impact, rather than a tradeoff in the quality of bachelor's degree earned.

\section{Cost-Benefit Discussion}

In order to provide a cost-benefit analysis for the Cal Grant program, we must first estimate the total cost of the program for the marginal student. Using data on total payments for each individual, the $\mathrm{RD}$ specification indicates that the marginal student received total payments across all years of $\$ 4,311$ at the GPA discontinuity and $\$ 8,115$ at the income discontinuity. This is substantially lower than the potential cost of roughly $\$ 36,000$ per student, which would be the case if all individuals received the full four years of private subsidy. The net costs are lower because not everyone above the threshold qualifies for the award, many do not attend more expensive private schools or choose to not use it, and some students leave college without using all four years of payments.

The implied wage gains at the GPA discontinuity suggest large benefits for this subset of Cal Grant recipients. We find wage increases of $5.4 \%$ for entire group of Cal Grant winners. If labor earnings average $\$ 39,000$ (Table 1), then the Cal Grant potentially creates a forty-year annuity of almost $\$ 2,106$ (i.e. $\$ 39,000 x 0.054$ ). At a 3 percent real discount rate, this annuity is worth roughly $\$ 48,700$ per recipient. This annuity is far in excess of the $\$ 4,000$ per recipient average cost. In fact, if we multiply by the likelihood of remaining in California times the marginal tax rate, the program would potentially pay for itself. This calculation, of course, assumes no general equilibrium effects on wages. If we instead use our estimate of a 1.33

\footnotetext{
${ }^{27}$ Regressions that use as outcome variables the interaction between earning a bachelor's degree ( $0 / 1$ dummy) and a continuous measure of degree quality such as graduation rate or expenditures are statistically insignificant, though point in the expected direction.
} 
percentile point increase in the wage distribution, this corresponds to an annuity of roughly $\$ 1,800$ which is worth roughly $\$ 42,800$.

The estimated wage gains are high and imprecise. We can also consider cost-benefit calculations using our estimated impacts on degree receipt. Our reduced form point estimate is that Cal Grant eligibility raises bachelor's degree receipt by three to four percentage points. The reduced form impacts vary across the two thresholds and suggest that the cost per degree differs: $\$ 93,717$ $(\$ 4,311 / 0.046)$ at the GPA threshold, and $\$ 270,500(\$ 8,115 / 0.030)$ at the income threshold. These results suggest cost-efficiencies for offering financial aid to theoretically less-prepared, lower GPA students, as they attend less expensive postsecondary institutions and at baseline are less likely to remain enrolled four years. Obviously, these estimates ignore any benefits that derive from graduate degree or other unobserved effects.

Because we find a larger response for lower income modest GPA students, our results suggest that targeting aid to lower income students (perhaps with some academic requirement) can be more efficient than broader aid programs. Further, Appendix Table A11 shows that these positive earnings effects are concentrated among the students coming from middle-income households, again highlighting that targeting is an important consideration for the design of financial aid programs. In particular, we suspect that some of the students near the income threshold (i.e. higher income but still aid-eligible students) are induced to attend more expensive private schools that may not increase students' graduation probabilities or long run earnings.

Using cost per degree as a primary metric, Cal Grant appears to be roughly as expensive as many other interventions studied in the literature. Financial aid studies using four-year students and military veterans are roughly in line with our estimates (Barr, 2016; Goldrick-Rab et al., 2016). Some studies focusing on need-based aid find estimates with a lower cost per additional bachelor's degree (Castleman \& Long, 2016; Mayer, Patel, \& Gutierrez, 2016). Earlier interventions such as Head Start and the Abecedarian experiments suggest costs of $\$ 133,000$ and $\$ 400,000$ simply to induce an additional child to attend college (Dynarski et al., 2013), and degree completion impacts are not guaranteed to be any larger. All of these programs have significant implementation and support costs, whereas interventions targeting small administrative barriers to college enrollment appear to be significantly cheaper (Bettinger et al., 
2012; Castleman, Page, \& Schooley, 2014; Hoxby \& Turner, 2013). Unfortunately, few of these studies have yet been able to assess long-term impacts on completion.

Using conventional returns to degree estimates, we note that moving an adult from some college to a bachelor's degree might raise earnings by an annuity of $\$ 20,000$ for forty years for a net present value of around $\$ 462,000$ at a 3\% interest rate. This compares favorably to the cost per additional degree of $\$ 81,000$ to $\$ 192,000$. This back-of-the-envelope calculation suggests that Cal Grant's increased graduation rates could easily "pay" for the program if we think of program costs as being more than offset by the increased earnings. This analysis is obviously highly simplistic because Cal Grant is really a transfer, just as the increased earnings could be a transfer from one worker to another as opposed to a societal gain. Importantly, the Cal Grant is largely a transfer from tax payers to students and their families. In other words, the Cal Grant is not a pure deadweight loss but rather a transfer which may or may not have a deadweight loss. Even if the earnings gains for the average student are smaller than the costs of administering the program, the program could still be welfare enhancing.

\section{Conclusion}

State sponsored merit- and need-based aid constitutes one of the most important and fastest growing sources of student assistance for postsecondary education. Cal Grant eligibility raises bachelor's degree attainment by three to 4.6 percentage points, with estimates based on award utilization over twice as large. Importantly, we do not find strong evidence that the increase in degree completion is strongly related to the sector of postsecondary enrollment. Our results suggest that large increases in degree completion occur primarily from increased persistence among students who begin in four-year institutions, rather than through changes in postsecondary sector. In fact, aid eligibility produces significant shifts from public to private universities for some students, but does not appear to drive any significant degree increases for this group above and beyond what is observed for other students.

We document that financial aid has additional effects on students' outcomes long after they have completed their undergraduate education. First, students at the GPA-eligibility margin are induced to complete graduate school by an additional three percentage points, an increase of roughly 26 percent. These findings show that financial aid can have a causal impact on additional 
human capital investment, particularly for lower-skilled students, perhaps through reducing debt that might prevent a student from temporarily exiting the workforce to pursue their graduate education. Another key insight is the long timeframe required to estimate these results, lending support to the importance of a life-cycle approach to estimating the returns to aid. Year-by-year analysis suggests that the graduate degree effect only becomes statistically significant seven years after entering college.

Our results also suggest positive impacts on in-state residency and earnings. These findings confirm the notion that state-based financial aid programs can improve state finances, and the costs of these programs may be overestimated without taking into account mobility and labor force outcomes. However, we cannot say with precision how the changes in institution type and bachelor's degree attainment translate into effects on lifetime earnings, as our standard errors incorporate much smaller earnings gains. Given our three to 4.6 percentage point increase in bachelor's degree attainment, a 5.4 percentage point increase in earnings would imply a very large return to bachelor's degree receipt if that were the main channel for the earnings effect. However, it is quite possible that Cal Grant eligibility impacts earnings through many channels, as it induces students to attend graduate school and shifts which institutions are attended. We also cannot observe other potential changes, such as increased time studying or other extracurricular activities (e.g., internships) that might become available as students are offered aid. More data and longer follow-up periods will be needed to truly understand earnings impacts.

One concern with our analysis is that all of these effects may be particular to the institutional context of California. California is a geographically large and diverse economy making outmigration already less likely than migration from smaller states. More importantly, Cal Grant is offered on top of a highly subsidized and broad-reaching public university and community college system. Smaller states with lower college going rates might see larger impacts on college going and outmigration (e.g., the large impacts on college attendance from Georgia's HOPE program (Dynarski 2000)). Equally important is that our inferences are restricted to a particular set of Cal Grant applicants: a set of students who have taken the time to file a FAFSA form and a Cal Grant application, and virtually all participate in college at some point following high school. Our estimates are also restricted to students at the eligibility cutoffs, whereas the largest effects on attendance and persistence might be concentrated on very low-income students, who are least 
likely to attend college. On the other hand, the Cal Grant award appears well-designed, as we show that the "first-dollar" structure does not crowd out other forms of financial aid such as Pell or federal tax credits. Alternative aid programs without these safeguards could produce smaller reduced form estimates than those observed in our study. Overall, our results suggest that financial aid does indeed produce long-term impacts on both educational and labor force outcomes, and that states should consider these potential benefits when designing or weighing the explicit costs of these programs. 


\section{References}

Barr, A. (2016). Fighting for Education: The Effect of the Post-9/11 GI Bill on Degree Attainment. Becker, G. (1975). Human Capital: A Theoretical and Empirical Analysis, with Special Reference to Education, 2nd edition: National Bureau of Economic Research.

Bettinger, E. P. (2004). How Financial Aid Affects Persistence. In C. M. Hoxby (Ed.), College Choices: The Economics of Where to Go, When to Go, and How to Pay For It. Chicago, IL: University of Chicago Press.

Bettinger, E. P., Kremer, M., Kugler, M., Medina, C., Posso, C., \& Saavedra, J. E. (2016). Educational, Labor Market, and Fiscal Impacts of Scholarships for Private Secondary School: Evidence from Colombia.

Bettinger, E. P., Long, B. T., Oreopoulos, P., \& Sanbonmatsu, L. (2012). The Role of Simplification and Information in College Decisions: Results from the H\&R Block FAFSA Experiment. Quarterly Journal of Economics, 127(3), 1205-1242.

Calonico, Sebastian, Matias D. Cattaneo, and Rocio Titiunik. "Robust nonparametric confidence intervals for regression-discontinuity designs." Econometrica 82.6 (2014): 2295-2326.

Castleman, B. L., \& Long, B. T. (2016). Looking beyond Enrollment: The Causal Effect of Need-Based Grants on College Access, Persistence, and Graduation. Journal of Labor Economics, 34(4), 1023-1073.

Castleman, B. L., Page, L. C., \& Schooley, K. (2014). The forgotten summer: Mitigating summer attrition among college-intending low-income high school graduates. Journal of Policy Analysis and Management, 32(2), 320-344.

Chapman, Stephanie. "Student Loans and the Labor Market: Evidence from Merit Aid Programs."

Northwestern University Department of Economics, Chicago, IL (2015).

Chetty, R., Friedman, J. N., Hilger, N., Saez, E., Schanzenbach, D. W., \& Yagan, D. (2011). How Does Your Kindergarten Classroom Affect Your Earnings? Evidence from Project Star. Quarterly Journal of Economics, 126(4), 1593-1660.

Chetty, R., Hendren, N., Kline, P., \& Saez, E. (2014). Where is the land of Opportunity? The Geography of Intergenerational Mobility in the United States. The Quarterly Journal of Economics. doi:10.1093/qje/qju022

Cohodes, S. R., \& Goodman, J. S. (2014). Merit Aid, College Quality and College Completion: Massachusetts' Adams Scholarship as an In-Kind Subsidy. American Economic Journal: Applied Economics, 6(4), 251-285.

Cornwell, C. M., Lee, K. H., \& Mustard, D. B. (2005). Student Responses to Merit Scholarship Retention Rules. Journal of Human Resources, 40(4), 895-917.

Cornwell, C. M., Mustard, D. B., \& Sridhar, D. J. (2006). The Enrollment Effects of Merit-Based Financial Aid: Evidence from Georgia's HOPE Program. Journal of Labor Economics, 24(4), 761-786.

DesJardins, S. L., McCall, B. P., Ott, M., \& Kim, J. (2010). A Quasi-Experimental Investigation of How the Gates Millennium Scholars Program Is Related to College Students' Time Use and Activities. Educational Evaluation and Policy Analysis, 32(4), 456-475.

Domina, T. (2014). Does Merit Aid Program Design Matter? A Cross-Cohort Analysis. Research in Higher Education, 55(1), 1-26.

Doyle, W. R. (2006). Adoption of Merit-Based Student Grant Programs: An Event History Analysis. Educational Evaluation and Policy Analysis, 28(3), 259-285.

Dynarski, S. M. (2000). Hope for Whom? Financial Aid for the Middle Class and Its Impact on College Attendance. National Tax Journal, 53(3), 629-662.

Dynarski, S. M. (2003). Does Aid Matter? Measuring the Effect of Student Aid on College Attendance and Completion. The American Economic Review, 93(1), 279-288. 
Dynarski, S. M. (2004). The New Merit Aid. In C. Hoxby (Ed.), College Choice: The Economics of Where to Go, When to Go, and How to Pay for It (pp. 63-97). Chicago, IL: University of Chicago Press.

Dynarski, S. M. (2008). Building the stock of college-educated labor. Journal of Human Resources, 43(3), 576-610.

Dynarski, S. M., Hemelt, S. W., \& Hyman, J. M. (2015). The missing manual: Using National Student Clearinghouse data to track postsecondary outcomes. Educational Evaluation and Policy Analysis, 37, 53S-79S.

Dynarski, S. M., Hyman, J., \& Schanzenbach, D. (2013). Experimental Evidence on the Effect of Childhood Investments on Postsecondary Attainment and Degree Completion. Journal of Policy Analysis and Management, 32(4), 692-717.

Fitzpatrick, M. D., \& Jones, D. (2012). Higher Education, Merit-Based Scholarsihps, and PostBaccalaureate Migration. NBER Working Paper 18530.

Goldrick-Rab, S., Kelchen, R., Harris, D. N., \& Benson, J. (2016). Reducing Income Inequality in Educational Attainment: Experimental Evidence on the Impact of Financial Aid on College Completion. American Journal of Sociology, 121(6), 1762-1817. doi:doi:10.1086/685442

Groen, J. A. (2004). The effect of college location on migration of college-educated labor. Journal of Econometrics, 121(1-2), 125-142.

Haider, S., \& Solon, G. (2006). Life-Cycle Variation in the Association between Current and Lifetime Earnings. American Economic Review, 96(4), 1308-1320.

Hanushek, E. A., \& Woessmann, L. (2015). The Knowledge Capital of Nations: Education and the Economics of Growth. Cambridge, MA: MIT Press.

Henry, G. T., \& Rubenstein, R. (2002). Paying for grades: Impact of merit-based financial aid on educational quality. Journal of Policy Analysis and Management, 21(1), 93-109.

Hoxby, C. M. (2009). The Changing Selectivity of American Colleges. Journal of Economic Perspectives, 23(4), 95-118. doi:doi: 10.1257/jep.23.4.95

Hoxby, Caroline M., and George B. Bulman. "The effects of the tax deduction for postsecondary tuition: Implications for structuring tax-based aid." Economics of Education Review 51 (2016): 23-60.

Hoxby, C. M., \& Turner, S. E. (2013). Expanding College Opportunities for High-Achieving, Low Income Students. Stanford Institute for Economic Policy Research.

Imbens, G. W., \& Kalyanaram, K. (2012). Optimal bandwidth choice for the regression discontinuity estimator. Review of Economic Studies, 142(2), 615-635.

Jackson, K., Johnson, R. C., \& Persico, C. (2016). The Effects of School Spending on Educational and Economic Outcomes: Evidence from School Finance Reforms. Quarterly Journal of Economics, 131(1), 157-218.

Kane, T. J. (2003). A Quasi-Experimental Estimate of the Impact of Financial Aid on College-Going. NBER Working Paper No. 9703.

Kane, T. J. (2007). Evaluating the Impact of the D.C. Tuition Assistance Grant Program. Journal of Human Resources, XLII(3), 555-582.

Lee, D., \& Card, D. (2008). Regression discontinuity inference with specification error. Journal of Econometrics, 142(2), 655-674.

Long, B. T. (2004). Does the format of a financial aid program matter? The effect of state in-kind tuition subsidies. The Review of Economics and Statistics, 86(3), 767-782.

Malamud, O., \& Wozniak, A. (2012). The Impact of College on Migration Evidence from the Vietnam Generation. Journal of Human Resources, 47(4), 913-950.

Mayer, A. K., Patel, R., \& Gutierrez, M. (2016). Four-Year Degree and Employment Findings From a Randomized Controlled Trial of a One-Year Performance-Based Scholarship Program in Ohio. Journal of Research on Educational Effectiveness, 9(3), 283-306. doi:10.1080/19345747.2015.1086914

McCrary, J. (2008). Manipulation of the running variable in the regression discontinuity design: A density test. Journal of Econometrics, 142(2), 698-714. 
NASSGAP. (2012). 43rd Annual Survey Report on State-Sponsored Student Financial Aid. National Association of State Student Grant and Aid Programs. Washington DC.

Oreopoulos, P., \& Petronijevic, U. (2013). Making College Worth It: A Review of Research on the Returns to Higher Education. The Future of Children, 23(1), 41-65.

Pallais, A. (2009). Taking a Chance on College: Is the Tennessee Education Lottery Scholarship Program a Winner? Journal of Human Resources, 44(1), 199-222.

Peltzman, S. (1973). The Effect of Government Subsidies-in-Kind on Private Expenditures: The Case of Higher Education Journal of Political Economy, 81(1), 1-27.

Scott-Clayton, J. (2011). On Money and Motivation: A Quasi-Experimental Analysis of Financial Incentives for College Achievement. Journal of Human Resources, 46(3), 614-646.

Scott-Clayton, J., \& Zafar, B. (2016). Financial Aid, Debt Management, and Socioeconomic Outcomes: Post-College Effects of Merit-Based Aid. NBER Working Paper No. 22574.

Seftor, N. S., \& Turner, S. E. (2002). Back to School: Federal Student Aid Policy and Adult College Enrollment. Journal of Human Resources, 37(2), 336-352.

Singell, L. D., \& Stone, J. A. (2002). The Good, the Poor, and the Wealthy: Who Responds Most to College Financial Aid? Bulletin of Economic Research, 54(4), 393-407.

Sjoquist, D. L., \& Winters, J. V. (2013). The effects of HOPE on post-college retention in the Georgia workforce. Regional Science and Urban Economics, 43(3), 479-490.

Sjoquist, D. L., \& Winters, J. V. (2014). Merit aid and post-college retention in the state. Journal of Urban Economics, 80, 39-50.

Sjoquist, D. L., \& Winters, J. V. (2015). State Merit-Aid Programs and College Major: A Focus on STEM. Journal of Labor Economics, 33(4), 973-1006.

Van Der Klaauw, W. (2002). Estimating the Effect of Financial Aid Offers on College Enrollment: A Regression-Discontinuity Approach. International Economic Review, 43(4), 1249-1287.

Wozniak, A. (2010). Are College Graduates More Responsive to Distant Labor Market Opportunities? Journal of Human Resources, 45(4), 944-970.

Zhang, L., \& Ness, E. C. (2010). Does State Merit-Based Aid Stem Brain Drain? Educational Evaluation and Policy Analysis, 32(2), 143-165. 


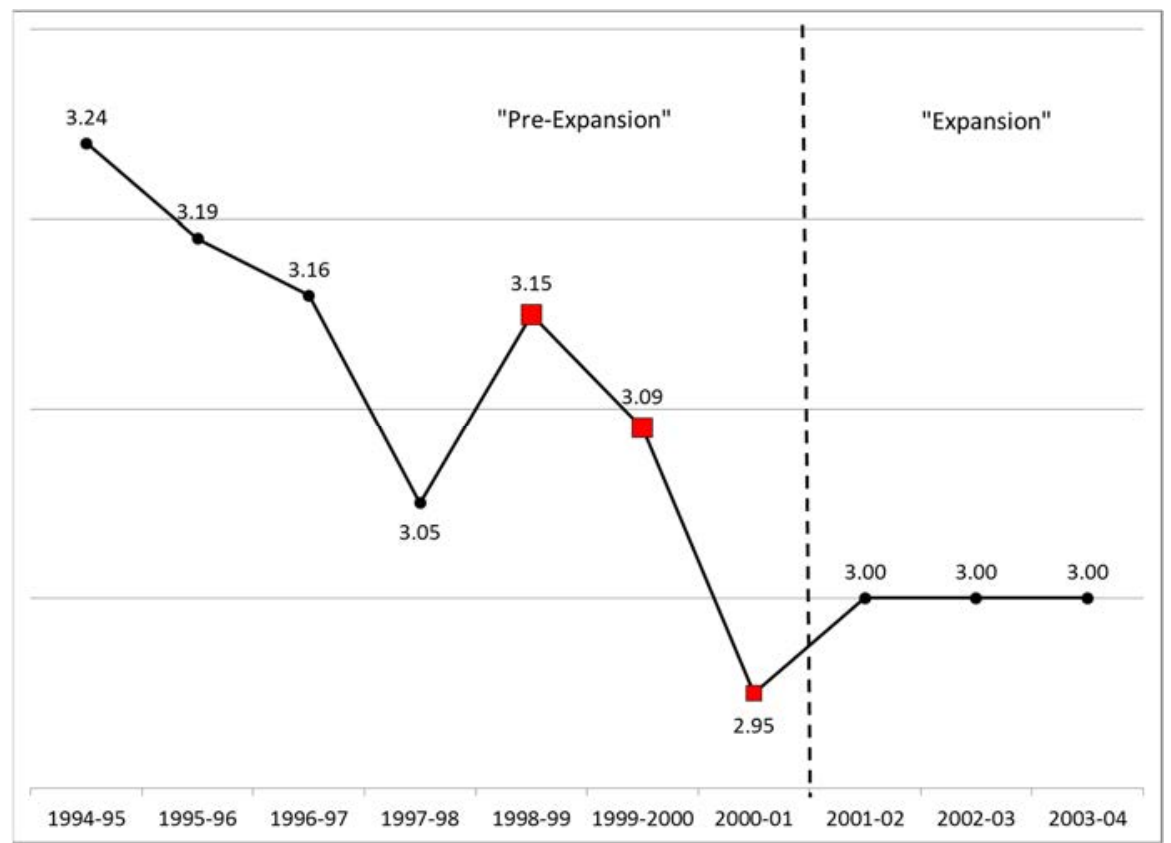

Figure 1. GPA CutofFs OVER TIME

Notes: This figure depicts the year-specific GPA thresholds for eligibility for Cal Grant A. Red squares indicate the years that are included in our analysis. 

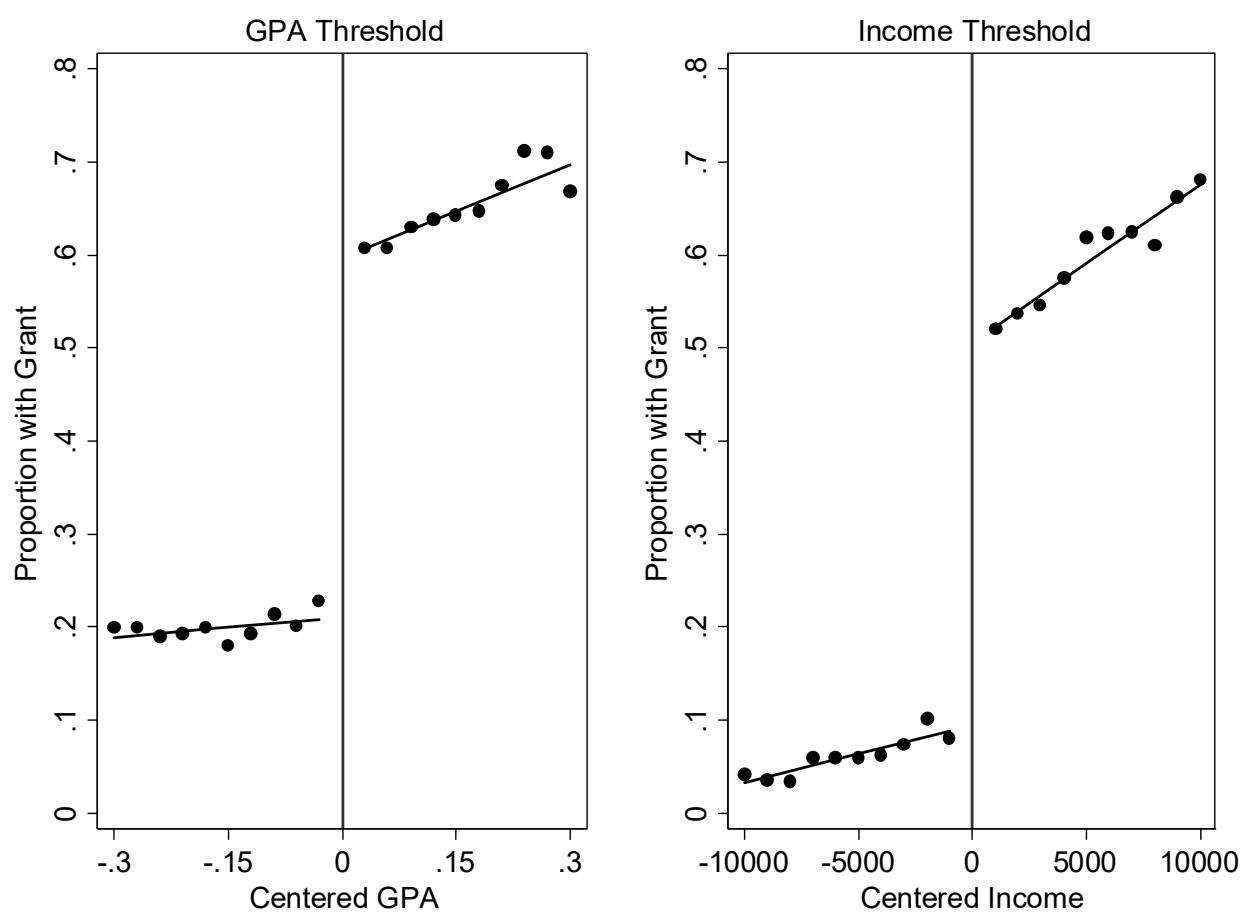

\section{Figure 2. Cal Grant Utilization}

Notes: This figure depicts the proportion of students who ever received a Cal Grant payment by bins of GPA and income around the Cal Grant eligibility threshold. The left panel bins students by $0.03 \mathrm{GPA}$ points relative to the year-specific eligibility threshold, pooled across years. The right panel bins students by $\$ 1,000$ relative to the year-specific eligibility threshold, pooled across years. Income is reversed so that values above the cutoff represent lower family incomes; in both panels, crossing the threshold from left to right indicates becoming eligible for the Cal Grant. 


\title{
Degree Completion Results
}

\author{
GPA Thresholds (binwidth $=0.03 \mathrm{GPA}$ )
}
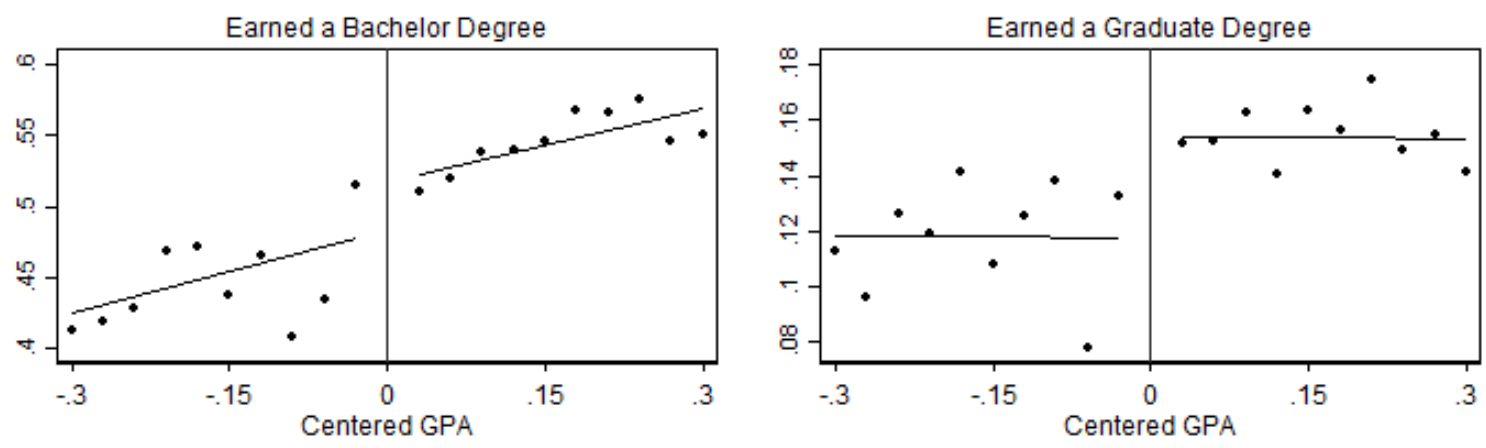

Income Threshold (binwidth $=\$ 1000)$
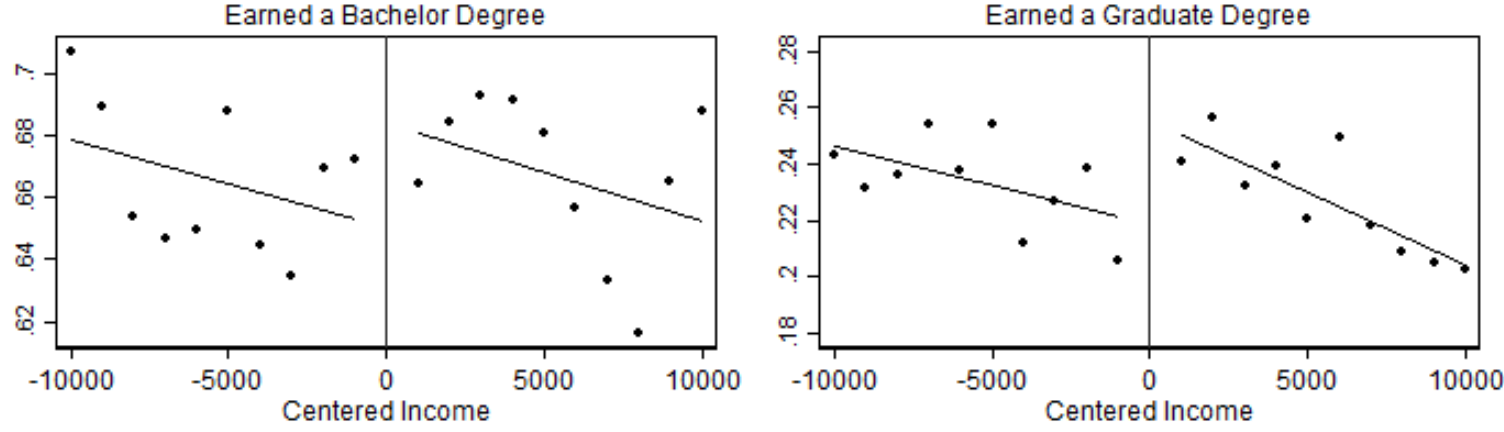

\section{Figure 3. Postsecondary Attainment}

Notes. This figure depicts the proportion of students who earned a bachelor's degree or a graduate degree, based on National Student Clearinghouse data for student's whose FAFSA indicates strong NSC coverage. The top panel bins students by 0.03 GPA points relative to the year-specific eligibility threshold, pooled across years. The bottom panel bins students by $\$ 1,000$ relative to the year-specific eligibility threshold, pooled across years. Income is reversed so that values above the cutoff represent lower family incomes; in both panels, crossing the threshold from left to right indicates becoming eligible for the Cal Grant. 


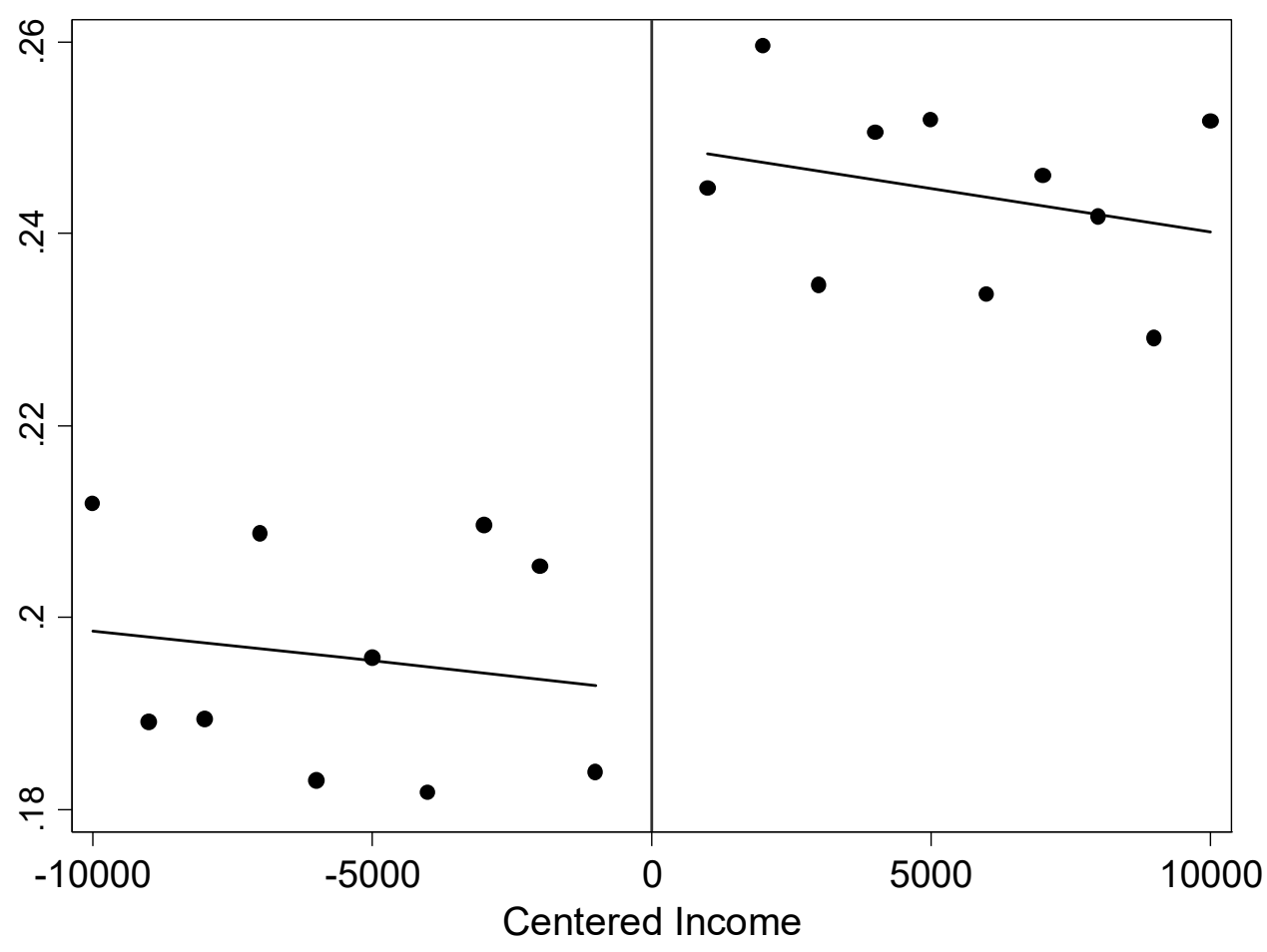

Figure 4. Attends Private Institution, Income Threshold

Notes: This figure plots the proportion of students around the income threshold who attended a private institution at any point between 1 and 4 years since their Cal Grant application, pooled over cohorts. Students are binned by $\$ 1,000$ relative to the year-specific eligibility threshold. College attendance is based off of Form 1098-T, and institution types are derived using IPEDs data. Income is reversed so that values above the cutoff represent lower family incomes; crossing the threshold from left to right indicates becoming eligible for the Cal Grant. 

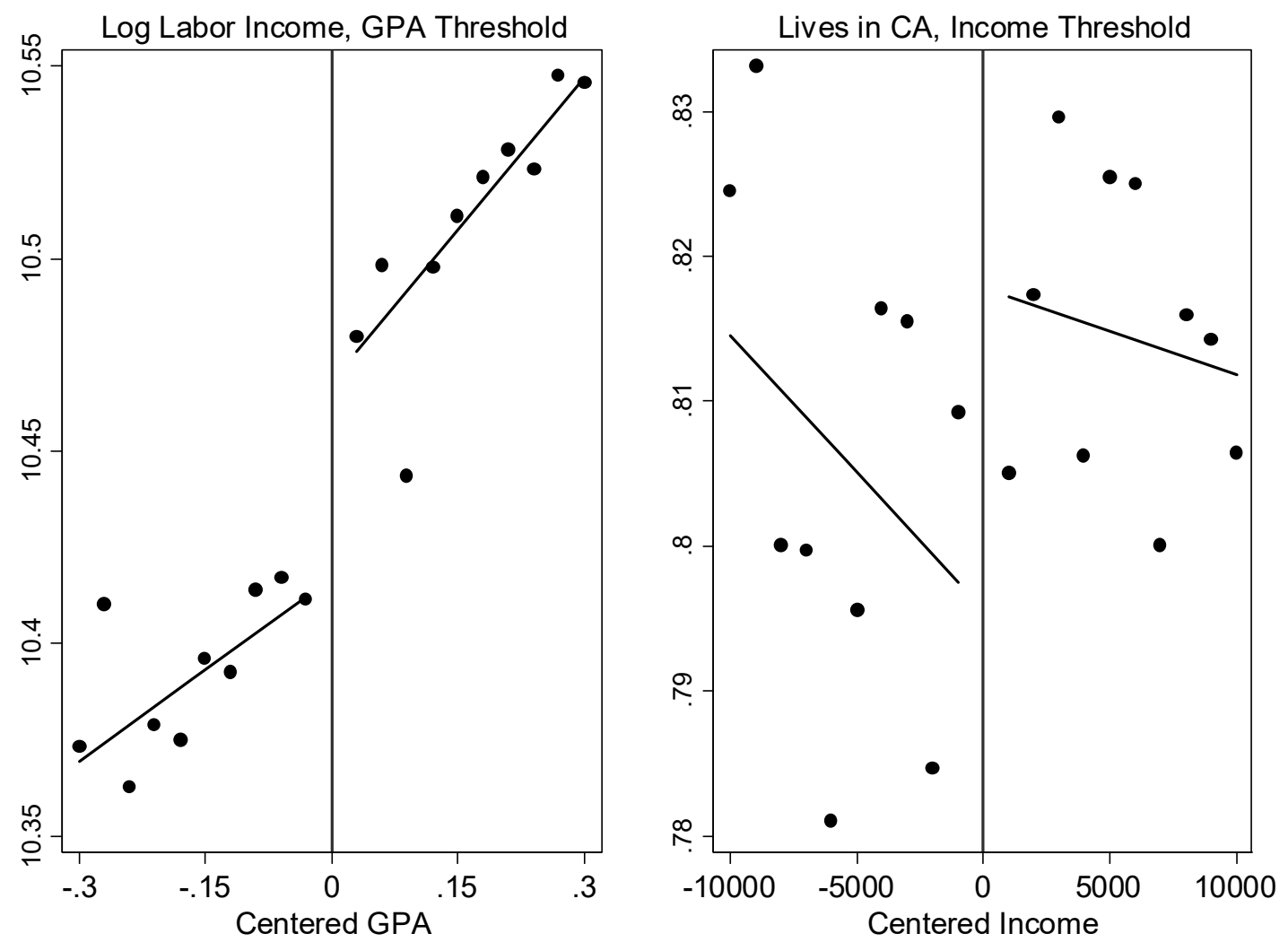

\section{Figure 5. SElect LONGER-Run OUtCOMeS, 10-14 YeARS AFTER APPLiCATION}

Notes: This figure plots the average log labor income (defined as the sum of W-2 wage and salary income and 1099-MISC non-employee compensation) for students around the GPA threshold, and the proportion of students living in California around the GPA threshold, stacked over 10-14 years after Cal Grant application and pooled over cohorts. The left panel bins students by 0.03 GPA points relative to the year-specific eligibility threshold; the right panel bins students by $\$ 1,000$ relative to the year-specific eligibility threshold. Income is reversed so that values above the cutoff represent lower family incomes; in both panels, crossing the threshold from left to right indicates becoming eligible for the Cal Grant. 


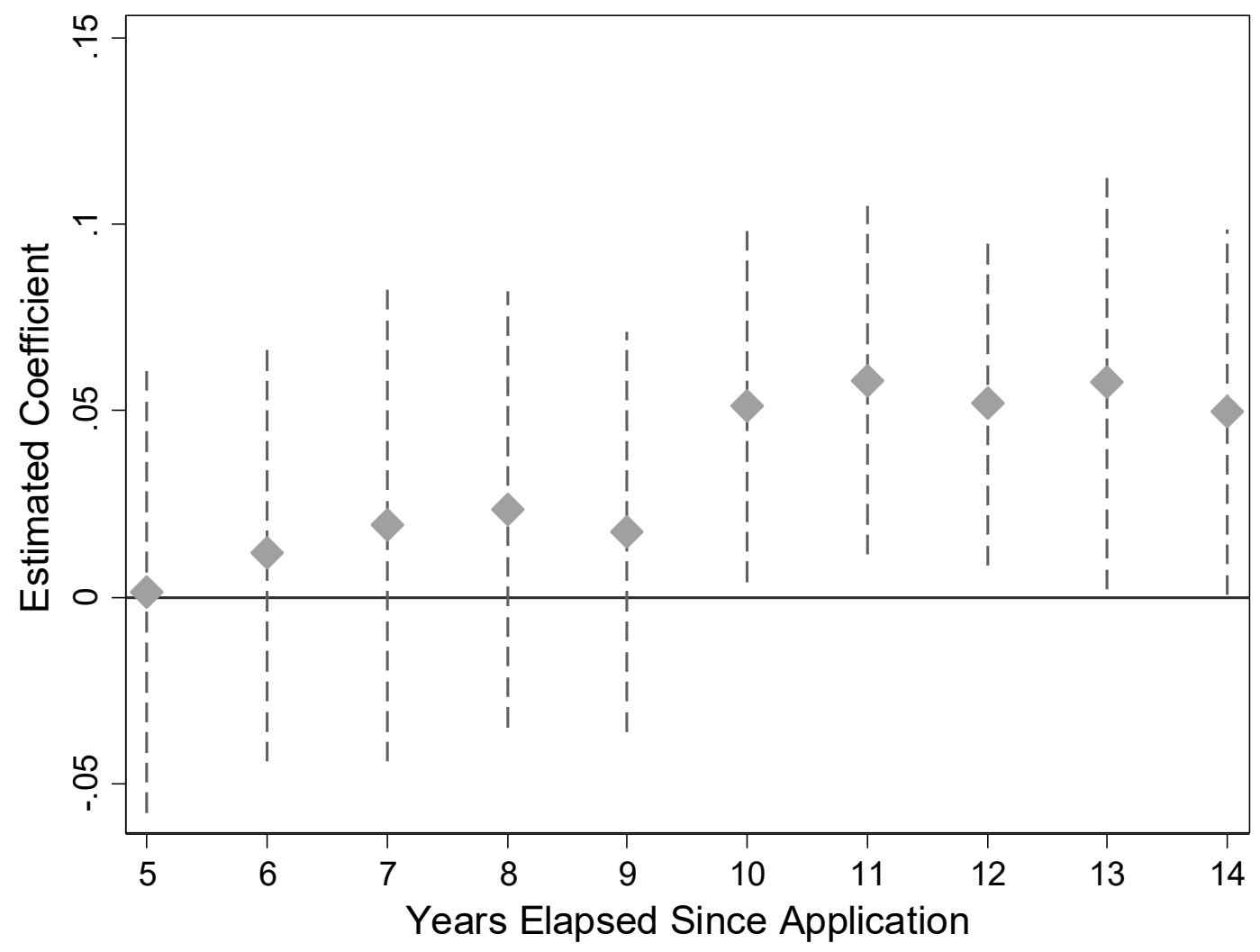

\section{FigURE 6. LOG LABOR INCOME, GPA THRESHOLD}

Notes: This figure plots the regression coefficients and $95 \%$ confidence intervals on a series of interactions between Cal Grant eligibility and years elapsed since application to the Cal Grant. The dependent variable is the log of labor income (defined as the sum of W-2 wage and salary income and 1099-MISC non-employee compensation). The regressions include students within 0.3 GPA points of the GPA threshold. The regressions include the student's age, a dummy for parental college attainment, a dummy for U.S. citizenship, a dummy for parents being married, family size by year fixed effects, and zip code fixed effects. Standard errors are clustered by the running variable. 


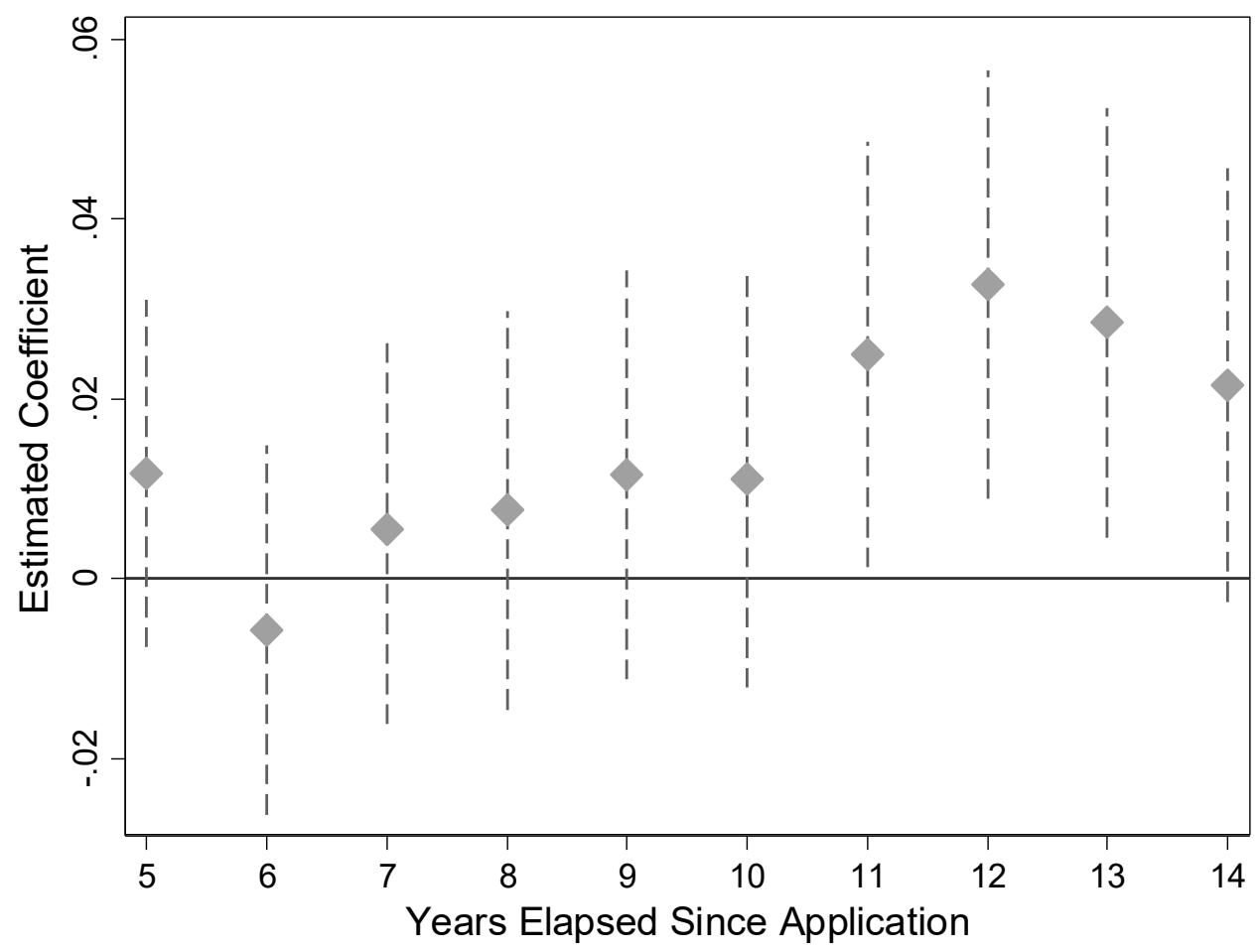

FiguRe 7. RESIDENCY RESUlts, InCOME THRESHOLd

Notes: This figure plots the regression coefficients and $95 \%$ confidence intervals on a series of interactions between Cal Grant eligibility and years elapsed since application to the Cal Grant. The dependent variable is an indicator variable for being a California resident, based on the filing address on a tax return. The regressions include students within $\$ 10,000$ of the income threshold. The regressions include the student's age, a dummy for parental college attainment, a dummy for U.S. citizenship, a dummy for parents being married, family size by year fixed effects, and zip code fixed effects. Standard errors are heteroscedasticity robust. 


\section{Demographics}

Age

Female

Citizen

Parents married

Dependent

GPA

Family income

\begin{tabular}{|c|c|}
\hline GPA Threshold & Income Threshold \\
\hline Std. Dev. & Mean $\quad$ Std. Dev. \\
\hline
\end{tabular}

$\begin{array}{cccc}18.54 & 2.33 & 18.24 & 1.18 \\ 0.56 & 0.50 & 0.58 & 0.49 \\ 0.86 & 0.34 & 0.94 & 0.24 \\ 0.44 & 0.50 & 0.53 & 0.50 \\ 0.97 & 0.16 & 1.00 & 0.07 \\ 3.08 & 0.18 & 3.55 & 0.28 \\ 35,103 & 14,490 & 60,492 & 7,971\end{array}$

Year 1 after Application

Attends school

0.83

0.37

0.93

0.25

0.77

0.42

0.86

0.35

Two-year public

0.25

0.43

0.16

0.37

0.44

0.50

0.54

0.50

Private school

0.09

0.29

0.15

0.36

Years 1-4 after Application

$\begin{array}{lllll}\text { Attends school } & 0.95 & 0.22 & 0.99 & 0.12 \\ \text { School in CA } & 0.91 & 0.29 & 0.93 & 0.25 \\ \text { Two-year public } & 0.42 & 0.49 & 0.27 & 0.44 \\ \text { Four-year public } & 0.58 & 0.49 & 0.67 & 0.47 \\ \text { Private school } & 0.09 & 0.29 & 0.15 & 0.36\end{array}$

Years 10-14 after Application

\begin{tabular}{lcccc} 
Files a tax return & 0.93 & 0.22 & 0.95 & 0.18 \\
Labor income & 39,014 & 28,301 & 46,978 & 31,481 \\
Household size-adjusted AGI & 45,665 & 53,051 & 57,346 & 63,327 \\
Married & 0.52 & 0.50 & 0.57 & 0.50 \\
Has kids & 0.46 & 0.50 & 0.41 & 0.49 \\
Lives in California & 0.89 & 0.31 & 0.86 & 0.35 \\
\hline
\end{tabular}

Note: The table provides means and standard deviations for all students at the GPA and income thresholds. The GPA subsample includes students within 0.3 of the GPA threshold, and the income subsample include students within $\$ 10,000$ of the income threshold. The demographic and college attendance variables are available for all applicants: 31,500 observations at the GPA threshold and 18,097 observations at the income threshold. The indicator for filing a tax return and wage income (based off of W-2s) are also available for all applicants. The tax-return based variables are only available for tax filers: 29,250 students at the GPA threshold and 17,252 students at the income threshold have available data at some point between 10 and 14 years after applying for the Cal Grant. 
Table 2. Educational Outcomes, NSC and 1098-T Data

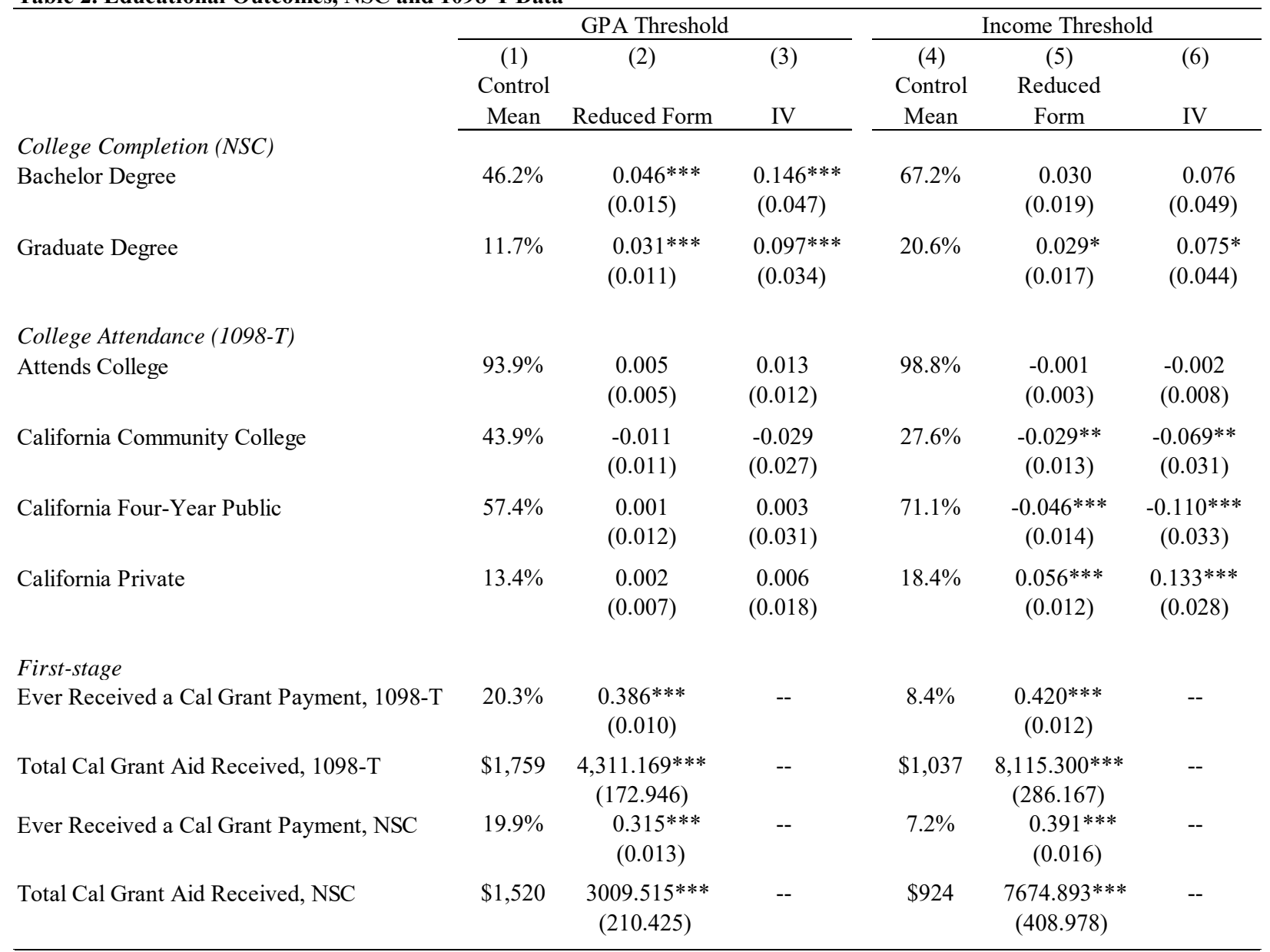

Notes. This table presents estimates of the effect of Cal Grant eligibility on college attendance outcomes. The IV regressions instrument for receiving a Cal Grant with eligibility status; results from the first-stage are presented in the bottom panel of the table. Regressions at the GPA threshold include applicants within 0.3 points of the GPA threshold, and regressions at the income threshold include applicants within $\$ 10,000$ of the income threshold. In specifications using NSC data, there are 31,836 and 18,588 observations at the GPA and income thresholds, respectively. In specifications using the 1098-T data, there are 31,500 and 18,097 observations at the income threshold, respectively. All regressions include student age, parental education, parental marital status, citizen status, and year-by-family size fixed effects. A linear function of the running variable and a uniform kernel are used. Standard errors clustered by GPA for GPA threshold regressions and are heteroscedasticity-robust in income threshold regressions. Reduced form control value means are average values for students within 0.05 points of the GPA threshold or within $\$ 1000$ of the income threshold.

$* \mathrm{p}<0.1, * * \mathrm{p}<0.05, * * * \mathrm{p}<0.01$. 
Table 3: Longer-Run Income and Demographic Outcomes, Tax Returns 10-14 Years after Application

\begin{tabular}{|c|c|c|c|c|c|c|}
\hline & \multicolumn{3}{|c|}{ GPA Threshold } & \multicolumn{3}{|c|}{ Income Threshold } \\
\hline & & Control & & & & \\
\hline & $\mathrm{N}$ & Mean & Reduced Form & $\mathrm{N}$ & Control Mean & Reduced Form \\
\hline Filed a Tax Return & 157,500 & $92.7 \%$ & $\begin{array}{c}0.004 \\
(0.005)\end{array}$ & 90,485 & $95.8 \%$ & $\begin{array}{l}-0.006 \\
(0.005)\end{array}$ \\
\hline Log labor income & 138,932 & 11.07 & $\begin{array}{c}0.054 * * * \\
(0.019)\end{array}$ & 81,651 & 10.49 & $\begin{array}{l}-0.020 \\
(0.024)\end{array}$ \\
\hline Income percentile & 157,442 & 41.89 & $\begin{array}{c}1.334 * * * \\
(0.491)\end{array}$ & 90,375 & 50.83 & $\begin{array}{c}-0.483 \\
(0.672)\end{array}$ \\
\hline Log Household size-adjusted AGI & 144,369 & 10.50 & $\begin{array}{l}0.032 * \\
(0.016)\end{array}$ & 84,999 & 10.77 & $\begin{array}{l}-0.005 \\
(0.022)\end{array}$ \\
\hline Lives in CA & 146,027 & $90.5 \%$ & $\begin{array}{l}-0.004 \\
(0.007)\end{array}$ & 85,991 & $86.4 \%$ & $\begin{array}{c}0.024 * * \\
(0.011)\end{array}$ \\
\hline Married & 146,424 & $53.1 \%$ & $\begin{array}{l}-0.014 \\
(0.010)\end{array}$ & 86,162 & $57.5 \%$ & $\begin{array}{c}0.005 \\
(0.013)\end{array}$ \\
\hline Has kids & 146,027 & $47.9 \%$ & $\begin{array}{c}-0.023 * * \\
(0.010)\end{array}$ & 85,991 & $40.7 \%$ & $\begin{array}{c}0.003 \\
(0.012)\end{array}$ \\
\hline
\end{tabular}

Notes. This table presents estimates of the effect of Cal Grant eligibility on long-run outcomes based on administrative tax data. Regressions at the GPA threshold include applicants within 0.3 points of the GPA threshold, and regressions at the income threshold include applicants within $\$ 10,000$ of the income threshold. All regressions include student age, parental education, parental marital status, citizen status, and year-by-family size fixed effects. A linear function of the running variable and a uniform kernel are used. Standard errors clustered by GPA for GPA threshold regressions and are heteroscedasticity-robust in income threshold regressions. Reduced form control value means are average values for students within 0.05 points of the GPA threshold or within $\$ 1000$ of the income threshold.

$* \mathrm{p}<0.1,{ }^{* *} \mathrm{p}<0.05, * * * \mathrm{p}<0.01$. 
Table 4. College Financing and College Characteristics

\begin{tabular}{|c|c|c|c|c|c|c|}
\hline \multirow{4}{*}{ College Characteristics, IPEDs } & \multicolumn{3}{|c|}{ GPA Threshold } & \multicolumn{3}{|c|}{ Income Threshold } \\
\hline & & Reduced & & \multirow{2}{*}{$\begin{array}{c}\text { Control } \\
\text { Mean }\end{array}$} & \multirow[b]{2}{*}{ Reduced Form } & \multirow[b]{2}{*}{ IV } \\
\hline & Control Mean & Form & IV & & & \\
\hline & & & & & & \\
\hline & 19,916 & $\begin{array}{c}232.800 \\
(221.467)\end{array}$ & $\begin{array}{c}565.622 \\
(528.308)\end{array}$ & 20,727 & $\begin{array}{c}-772.875 * * \\
(319.756)\end{array}$ & $\begin{array}{c}-1,822.013 * * \\
(753.593)\end{array}$ \\
\hline Tuition & $\$ 3,786.5$ & $\begin{array}{c}136.277 \\
(121.892)\end{array}$ & $\begin{array}{c}331.104 \\
(292.823)\end{array}$ & $\$ 6,066.6$ & $\begin{array}{c}903.470 * * * \\
(238.533)\end{array}$ & $\begin{array}{c}2,129.993 * * * \\
\quad(553.801)\end{array}$ \\
\hline $150 \%$ time to graduation & $42.8 \%$ & $\begin{array}{l}0.006^{*} \\
(0.003)\end{array}$ & $\begin{array}{c}0.015 * * \\
(0.007)\end{array}$ & $54.8 \%$ & $\begin{array}{c}0.005 \\
(0.006)\end{array}$ & $\begin{array}{c}0.011 \\
(0.014)\end{array}$ \\
\hline "Median" SAT score & 1046.4 & $\begin{array}{l}4.741 \\
(2.887)\end{array}$ & $\begin{array}{l}9.016^{*} \\
(5.445)\end{array}$ & 1122.2 & $\begin{array}{l}-0.015 \\
(4.067)\end{array}$ & $\begin{array}{l}-0.034 \\
(9.024)\end{array}$ \\
\hline Instruction expenditure per FTE & $\$ 6,114.9$ & $\begin{array}{l}113.158 \\
(94.358)\end{array}$ & $\begin{array}{c}266.986 \\
(218.982)\end{array}$ & $\$ 8,914.4$ & $\begin{array}{l}-103.078 \\
(187.745)\end{array}$ & $\begin{array}{l}-239.890 \\
(437.574)\end{array}$ \\
\hline Academic support per FTE & $\$ 3,633.2$ & $\begin{array}{c}-2.886 \\
(65.909)\end{array}$ & $\begin{array}{c}-7.011 \\
(158.777)\end{array}$ & $\$ 4,629.3$ & $\begin{array}{c}-353.738 * * * \\
(110.637)\end{array}$ & $\begin{array}{c}-833.920 * * * \\
(263.080)\end{array}$ \\
\hline Research expenditures per FTE & $\$ 1,728.6$ & $\begin{array}{c}143.911^{*} \\
(80.266)\end{array}$ & $\begin{array}{l}339.545^{*} \\
(185.389)\end{array}$ & $\$ 4,343.5$ & $\begin{array}{l}-396.480 * \\
(213.108)\end{array}$ & $\begin{array}{l}-922.718^{*} \\
(498.708)\end{array}$ \\
\hline Expenditures per FTE & $\$ 16,971.8$ & $\begin{array}{c}163.892 \\
(316.172)\end{array}$ & $\begin{array}{c}386.688 \\
(737.474)\end{array}$ & $\$ 25,717.8$ & $\begin{array}{l}-820.677 \\
(823.184)\end{array}$ & $\begin{array}{l}-1,909.939 \\
(1,919.428)\end{array}$ \\
\hline College Financing & & & & & & \\
\hline Has student loan & $70.1 \%$ & $\begin{array}{l}-0.006 \\
(0.009)\end{array}$ & $\begin{array}{l}-0.016 \\
(0.023)\end{array}$ & $73.8 \%$ & $\begin{array}{l}-0.002 \\
(0.013)\end{array}$ & $\begin{array}{l}-0.004 \\
(0.030)\end{array}$ \\
\hline Student loan amount & $\$ 22,114.8$ & $\begin{array}{c}387.268 \\
(946.225)\end{array}$ & $\begin{array}{c}1,003.287 \\
(2,424.087)\end{array}$ & $\$ 27,808.9$ & $\begin{array}{c}1,677.269 \\
(1,315.716)\end{array}$ & $\begin{array}{c}3,991.815 \\
(3,118.000)\end{array}$ \\
\hline Has Pell Grant & $14.4 \%$ & $\begin{array}{l}-0.011 \\
(0.009)\end{array}$ & $\begin{array}{l}-0.029 \\
(0.022)\end{array}$ & $3.5 \%$ & $\begin{array}{c}-0.011 * \\
(0.006)\end{array}$ & $\begin{array}{l}-0.027 * \\
(0.014)\end{array}$ \\
\hline Pell Grant Amount & $\$ 959.9$ & $\begin{array}{l}-25.424 \\
(18.367)\end{array}$ & $\begin{array}{l}-65.865 \\
(47.423)\end{array}$ & $\$ 58.6$ & $\begin{array}{l}-13.826 \\
(9.358)\end{array}$ & $\begin{array}{l}-32.904 \\
(22.343)\end{array}$ \\
\hline Has Federal education tax credit & $30.2 \%$ & $\begin{array}{l}-0.001 \\
(0.010)\end{array}$ & $\begin{array}{l}-0.004 \\
(0.026)\end{array}$ & $51.0 \%$ & $\begin{array}{l}-0.004 \\
(0.014)\end{array}$ & $\begin{array}{l}-0.008 \\
(0.033)\end{array}$ \\
\hline Federal education tax credit amount & $\$ 482.8$ & $\begin{array}{c}4.562 \\
(33.908)\end{array}$ & $\begin{array}{c}11.817 \\
(87.099)\end{array}$ & $\$ 617.4$ & $\begin{array}{c}73.436 \\
(58.345)\end{array}$ & $\begin{array}{c}174.774 \\
(138.638)\end{array}$ \\
\hline
\end{tabular}

Notes. This table presents estimates of the effect of Cal Grant eligibility on the college quality and financing measures. The IV regressions instrument for receiving a $\mathrm{Cal}$ Grant with eligibility status. The dependent variables in the top panel are derived from IPEDs data that are matched to the first Form 1098-T matched to each applicant after their Cal Grant application (within 4 years). The dependent variables in the bottom panel come from National Student Loan Data System or from the tax return of either the applicant or her parent. Regressions at the GPA threshold include applicants within 0.3 points of the GPA threshold, and regressions at the income threshold include applicants within $\$ 10,000$ of the income threshold. There are 31,500 and 18,097 observations at the income threshold, respectively. All regressions include student age, parental education, parental marital status, citizen status, and year-by-family size fixed effects. A linear function of the running variable and a uniform kernel are used. Standard errors clustered by GPA for GPA threshold regressions and are heteroscedasticity-robust in income threshold regressions. Reduced form control value means are average values for students within 0.05 points of the GPA threshold or within $\$ 1000$ of the income threshold. 


\section{ONLINE APPENDIX}

\section{Appendix 1. Discrepancies between Bettinger, Gurantz, Kawano, Sacerdote, and Stevens (2017) and Kane (2003)}

In contrast to our study, Kane (2003) finds that being awarded a Cal Grant increases immediate college enrollment at both the GPA and income thresholds. In this Appendix, we explore the possible explanations for the discrepancy in our results.

1. Kane's primary findings may be overstated by the general research audience: Kane's paper shows that statistically significant attendance impacts at the GPA threshold are only found for the 1998 cohort. The largest effect is a 4.2 percentage point increase in college enrollment when restricting the sample to only students with full NSC coverage. However, using the same subsample in the 1999 cohort Kane finds an increase of only 0.5 percentage points, suggesting a much smaller "true" effect. The general research audience tends to quote the 1998 impact, without the broader context of null effects in 1999. Kane’s income results are also on the margin of significance, but are broadly similar to our results.

2. Sample construction: In contrast to Kane (2003), we were able to construct the analytic sample ourselves, rather having CSAC to create the dataset. As a result, there may be a number of differences between our final dataset and his. Some immediate differences are listed below:

a. We are able to include one additional year of data from the 2000 applicant cohort.

b. Kane's full samples in 1998 and 1999 are 20\% and 10\% larger than ours, respectively. It is unclear why our sample is smaller, though a small part of this is due to differences in NSC matching (by restricting to within 0.6 GPA points of the threshold in 1998 we lose about 350 students between 3.50 and 3.55 GPA). Even though his sample is only slightly larger than ours, the magnitude of our standard errors when running year-by-year results is roughly twice those of Kane.

c. We are able to eliminate low-income students who are eligible for Cal Grant B, thus improving the treatment-control contrast for the group of students we label "low-income" and Kane labels "Fin. Eligible for B or A".

3. Functional form issues: Kane's insight in using a regression discontinuity to identify causal treatment effects was a significant step forward for economic research. In the intervening years, the RD treatment effects literature has recommended a number of suggestions and innovations to credibly identify causal impacts, which were not common at the time. A number of Kane's choices are now less standard in the literature, including:

a. Kane uses the full sample of students with GPA between 2.5 and 3.6, rather than a narrow bandwidth around the discontinuity. His sample is roughly twice our preferred bandwidth, and the paper provides no bandwidth robustness checks. 
b. His main GPA specification utilizes cubic polynomials and the income specification utilizes fourth degree polynomials, rather than the now generally standard local linear regression. His quadratic GPA robustness check is only marginally significant on his subsample, and insignificant for the full sample. There are no linear results shown.

c. Based on the description within the paper, it is unclear whether he allows his slope variables to vary across the thresholds.

d. There do not appear to be any standard error adjustments, such as those advocated by Lee and Card (2008), which could push his initial results towards statistical insignificance.

e. He estimates impacts using a probit with marginal effects, rather than in an OLS framework, though based on our comparisons of these two methods we do not believe this would change any of the results.

In Appendix Table A1, we show results that attempt to mimic Kane's paper, focusing only on Kane's "Financially eligible for A only" sample. We use enrollment based on NSC data as our outcome variable. In particular, we use cubic polynomials to estimate slopes over the full 2.5 to 3.6 GPA bandwidth, compare OLS to probits, and vary the functional forms. Using these specifications, and assuming the functional form is allowed to vary on either side of the discontinuity, we get results that are slightly more similar to Kane's results. Nonetheless, our results are imprecise and statistically insignificant within each individual year.

Appendix Table A1. Postsecondary enrollment, GPA threshold, Kane (2003) results

\begin{tabular}{lcrrrrrr}
\hline Model & OLS & OLS & Probit & Probit & Probit & Probit & Probit \\
Functional form & Linear & Cubic & Cubic & Cubic & Cubic & Quadratic & Quartic \\
Slope varies across threshold & $\mathrm{Y}$ & $\mathrm{Y}$ & $\mathrm{Y}$ & $\mathrm{Y}$ & $\mathrm{N}$ & $\mathrm{Y}$ & $\mathrm{Y}$ \\
Covariates & $\mathrm{N}$ & $\mathrm{N}$ & $\mathrm{N}$ & $\mathrm{Y}$ & $\mathrm{Y}$ & $\mathrm{Y}$ & $\mathrm{Y}$ \\
\cline { 2 - 8 } & & & & & & & \\
GPA Threshold & & & & & & & \\
Cohort=1998 & 0.007 & 0.041 & 0.041 & 0.040 & -0.001 & 0.006 & 0.032 \\
& $(0.019)$ & $(0.038)$ & $(0.038)$ & $(0.038)$ & $(0.025)$ & $(0.029)$ & $(0.047)$ \\
$\mathrm{N}$ & 9794 & 9794 & 9794 & 9658 & 9658 & 9658 & 9658 \\
& & & & & & & \\
Cohort=1999 & 0.009 & 0.031 & 0.031 & 0.031 & 0.015 & 0.020 & 0.046 \\
& $(0.018)$ & $(0.035)$ & $(0.035)$ & $(0.036)$ & $(0.024)$ & $(0.027)$ & $(0.045)$ \\
$\mathrm{N}$ & 10632 & 10632 & 10632 & 10060 & 10060 & 10060 & 10060 \\
\hline
\end{tabular}

Notes: ${ }^{*} \mathrm{p}<0.1,{ }^{* *} \mathrm{p}<0.05,{ }^{* * *} \mathrm{p}<0.01$. All regressions include students with GPA between 2.5 and 3.6. Standard errors are unadjusted in all regressions. 


\section{Appendix 2. Tables and Figures Referenced in the Main Text}

Appendix Table A2: Smoothness of Covariates

\begin{tabular}{|c|c|c|c|c|c|c|c|c|}
\hline \multirow{3}{*}{ GPA Threshold } & \multicolumn{8}{|c|}{ Covariates } \\
\hline & Student GPA & $\begin{array}{l}\text { Family } \\
\text { Income }\end{array}$ & Age & Female & $\begin{array}{c}\text { Parent college } \\
\text { educated }\end{array}$ & Citizen & $\begin{array}{l}\text { Parents } \\
\text { married }\end{array}$ & Family size \\
\hline & & & & & & & & \\
\hline Tax data & & $\begin{array}{c}24.090 \\
(186.613)\end{array}$ & $\begin{array}{c}0.056 \\
(0.072)\end{array}$ & $\begin{array}{l}-0.006 \\
(0.013)\end{array}$ & $\begin{array}{c}0.002 \\
(0.009)\end{array}$ & $\begin{array}{c}0.004 \\
(0.007)\end{array}$ & $\begin{array}{l}-0.001 \\
(0.009)\end{array}$ & $\begin{array}{c}0.010 \\
(0.029)\end{array}$ \\
\hline NSC data & & $\begin{array}{c}-49.157 \\
(173.000)\end{array}$ & $\begin{array}{r}-0.009 \\
(0.014)\end{array}$ & $\begin{array}{r}0.006 \\
(0.011)\end{array}$ & $\begin{array}{r}0.000 \\
(0.009)\end{array}$ & $\begin{array}{r}0.002 \\
(0.011)\end{array}$ & $\begin{array}{r}-0.000 \\
(0.014)\end{array}$ & $\begin{array}{l}-0.013 \\
(0.024)\end{array}$ \\
\hline Income Th & & & & & & & & \\
\hline Tax data & $\begin{array}{c}0.003 \\
(0.008)\end{array}$ & & $\begin{array}{l}-0.027 \\
(0.033)\end{array}$ & $\begin{array}{c}0.014 \\
(0.017)\end{array}$ & $\begin{array}{c}0.018 \\
(0.014)\end{array}$ & $\begin{array}{c}0.009 \\
(0.007)\end{array}$ & $\begin{array}{l}-0.003 \\
(0.008)\end{array}$ & $\begin{array}{l}-0.034 \\
(0.036)\end{array}$ \\
\hline NSC data & $\begin{array}{r}0.002 \\
(0.008) \\
\end{array}$ & & $\begin{array}{r}0.015 \\
(0.016) \\
\end{array}$ & $\begin{array}{r}0.002 \\
(0.015) \\
\end{array}$ & $\begin{array}{r}0.017 \\
(0.014) \\
\end{array}$ & $\begin{array}{r}0.008 \\
(0.009) \\
\end{array}$ & $\begin{array}{r}-0.009 \\
(0.011)\end{array}$ & $\begin{array}{r}-0.014 \\
(0.032)\end{array}$ \\
\hline
\end{tabular}

Notes. This table presents estimates of the effect of Cal Grant eligibility on applicant's demographic characteristics. Regressions at the GPA threshold include applicants within 0.3 points of the GPA threshold, and regressions at the income threshold include applicants within $\$ 10,000$ of the income threshold. There are 31,500 and 18,097 observations at the income threshold, respectively. All regressions include year-by-family size fixed effects, except when family size is the outcome. A linear function of the running variable and a uniform kernel are used. Standard errors clustered by GPA for GPA threshold regressions and are heteroscedasticity-robust in income threshold regressions. Regressions using female as the outcome variable only include the 1999 and 2000 cohorts because of missing data problems with the 1998 cohort (sample sizes are 20,377 and 12,398 for the GPA threshold and income threshold, respectively).

${ }^{*} \mathrm{p}<0.1,{ }^{* *} \mathrm{p}<0.05, * * * \mathrm{p}<0.01$. 
Appendix Table A3. Educational Outcomes, NSC data

\begin{tabular}{|c|c|c|c|c|c|c|}
\hline & \multicolumn{2}{|c|}{ GPA } & \multirow[b]{2}{*}{ IV } & \multicolumn{2}{|c|}{ Income } & \multirow[b]{2}{*}{ IV } \\
\hline & Mean & Estimate & & Mean & Estimate & \\
\hline \multicolumn{7}{|l|}{ College Completion (NSC) } \\
\hline Bachelor Degree & $46.2 \%$ & $\begin{array}{l}0.046 * * * \\
(0.015)\end{array}$ & $\begin{array}{l}0.146^{* * *} \\
(0.047)\end{array}$ & $67.2 \%$ & $\begin{array}{r}0.030 \\
(0.019)\end{array}$ & $\begin{array}{r}0.076 \\
(0.049)\end{array}$ \\
\hline Graduate Degree & $11.7 \%$ & $\begin{array}{l}0.031^{* * *} \\
(0.011)\end{array}$ & $\begin{array}{l}0.097 * * * \\
(0.034)\end{array}$ & $20.6 \%$ & $\begin{array}{c}0.029 * \\
(0.017)\end{array}$ & $\begin{array}{c}0.075^{*} \\
(0.044)\end{array}$ \\
\hline \multicolumn{7}{|l|}{ College Attendance } \\
\hline Attend & $74.9 \%$ & $\begin{array}{c}0.019 * \\
(0.010)\end{array}$ & $\begin{array}{c}0.059 * \\
(0.031)\end{array}$ & $85.9 \%$ & $\begin{array}{c}0.009 \\
(0.015)\end{array}$ & $\begin{array}{r}0.023 \\
(0.038)\end{array}$ \\
\hline Community College & $40.2 \%$ & $\begin{array}{r}-0.005 \\
(0.013)\end{array}$ & $\begin{array}{r}-0.016 \\
(0.040)\end{array}$ & $26.7 \%$ & $\begin{array}{c}-0.027 \\
(0.018)\end{array}$ & $\begin{array}{r}-0.068 \\
(0.046)\end{array}$ \\
\hline Four-Year Public & $35.6 \%$ & $\begin{array}{r}0.016 \\
(0.015)\end{array}$ & $\begin{array}{c}0.051 \\
(0.045)\end{array}$ & $52.1 \%$ & $\begin{array}{l}-0.019 \\
(0.021)\end{array}$ & $\begin{array}{r}-0.050 \\
(0.053)\end{array}$ \\
\hline Private & $8.5 \%$ & $\begin{array}{r}0.007 \\
(0.007)\end{array}$ & $\begin{array}{r}0.024 \\
(0.023)\end{array}$ & $15.8 \%$ & $\begin{array}{l}0.042^{* * *} \\
(0.016)\end{array}$ & $\begin{array}{l}0.107^{* * * *} \\
(0.040)\end{array}$ \\
\hline \multicolumn{7}{|l|}{ First-Stage } \\
\hline Ever received a Cal Grant payment & $19.9 \%$ & $\begin{array}{l}0.315^{* * *} \\
(0.013)\end{array}$ & -- & $7.2 \%$ & $\begin{array}{l}0.391^{* * *} \\
(0.016)\end{array}$ & -- \\
\hline Total Cal Grant Aid Received & $\$ 1,520$ & $\begin{array}{l}3009.515^{* * *} \\
(210.425)\end{array}$ & -- & $\$ 924$ & $\begin{array}{l}7674.893^{* * *} \\
(408.978)\end{array}$ & -- \\
\hline
\end{tabular}

Notes. This table presents estimates of the effect of Cal Grant eligibility on college attendance outcomes using the NSC data. The IV regressions instrument for receiving a Cal Grant with eligibility status; results from the first-stage are presented in the bottom panel of the table. Regressions at the GPA threshold include applicants within 0.3 points of the GPA threshold, and regressions at the income threshold include applicants within $\$ 10,000$ of the income threshold. All regressions include student age, parental education, parental marital status, citizen status, and year-by-family size fixed effects. Standard errors clustered by GPA for GPA threshold regressions and are heteroscedasticity-robust in income threshold regressions. Reduced form control value means are average values for students within 0.05 points of the GPA threshold or within $\$ 1000$ of the income threshold.

${ }^{*} \mathrm{p}<0.1,{ }^{* *} \mathrm{p}<0.05, * * * \mathrm{p}<0.01$. 
Appendix Table A4. Robustness of Educational Attainment Results to Varying Bandwidths

\begin{tabular}{|c|c|c|c|c|c|c|c|}
\hline \multicolumn{8}{|l|}{ GPA Threshold } \\
\hline Bandwidth & 0.1 & 0.2 & 0.3 & 0.4 & 0.5 & 0.6 & CCT \\
\hline Receives Cal Grant & $\begin{array}{c}0.372 * * * \\
(0.011)\end{array}$ & $\begin{array}{c}0.387 * * * \\
(0.011)\end{array}$ & $\begin{array}{c}0.386 * * * \\
(0.010)\end{array}$ & $\begin{array}{c}0.398 * * * \\
(0.008)\end{array}$ & $\begin{array}{c}0.243 * * * \\
(0.023)\end{array}$ & $\begin{array}{c}0.227 * * * \\
(0.020)\end{array}$ & $\begin{array}{c}0.376^{* * *} \\
(0.010)\end{array}$ \\
\hline Cal Grant payment & $\begin{array}{c}4,061.010^{* * *} \\
\quad(204.620)\end{array}$ & $\begin{array}{c}4,265.655^{* * *} \\
(190.579)\end{array}$ & $\begin{array}{c}4,311.169 * * * \\
\quad(172.946)\end{array}$ & $\begin{array}{c}4,582.296 * * * \\
\quad(153.525)\end{array}$ & $\begin{array}{c}2,937.518 * * * \\
\quad(269.016)\end{array}$ & $\begin{array}{c}2,870.417 * * * \\
\quad(228.699)\end{array}$ & $\begin{array}{c}4,133.569 * * * \\
(188.845)\end{array}$ \\
\hline Ever attends & $\begin{array}{l}-0.002 \\
(0.010)\end{array}$ & $\begin{array}{c}0.003 \\
(0.006)\end{array}$ & $\begin{array}{c}0.005 \\
(0.005)\end{array}$ & $\begin{array}{c}0.004 \\
(0.004)\end{array}$ & $\begin{array}{c}0.002 \\
(0.003)\end{array}$ & $\begin{array}{c}0.003 \\
(0.002)\end{array}$ & $\begin{array}{c}0.002 \\
(0.007)\end{array}$ \\
\hline CA Community College & $\begin{array}{c}-0.030^{* *} \\
(0.012)\end{array}$ & $\begin{array}{c}-0.024^{* *} \\
(0.011)\end{array}$ & $\begin{array}{l}-0.011 \\
(0.011)\end{array}$ & $\begin{array}{l}-0.015 \\
(0.009)\end{array}$ & $\begin{array}{l}-0.011^{*} \\
(0.006)\end{array}$ & $\begin{array}{c}-0.013^{* *} \\
(0.006)\end{array}$ & $\begin{array}{c}-0.029 * * \\
(0.013)\end{array}$ \\
\hline CA Four-Year Public & $\begin{array}{l}-0.004 \\
(0.020)\end{array}$ & $\begin{array}{c}0.004 \\
(0.014)\end{array}$ & $\begin{array}{c}0.001 \\
(0.012)\end{array}$ & $\begin{array}{l}-0.002 \\
(0.010)\end{array}$ & $\begin{array}{c}0.001 \\
(0.006)\end{array}$ & $\begin{array}{l}-0.006 \\
(0.005)\end{array}$ & $\begin{array}{c}0.010 \\
(0.016)\end{array}$ \\
\hline CA Private & $\begin{array}{c}0.005 \\
(0.009)\end{array}$ & $\begin{array}{c}0.004 \\
(0.008)\end{array}$ & $\begin{array}{c}0.002 \\
(0.007)\end{array}$ & $\begin{array}{l}0.010 * \\
(0.006)\end{array}$ & $\begin{array}{c}0.011 * * \\
(0.005)\end{array}$ & $\begin{array}{c}0.015^{* * *} \\
(0.004)\end{array}$ & $\begin{array}{l}-0.003 \\
(0.008)\end{array}$ \\
\hline Bachelor's degree & $\begin{array}{r}0.028 \\
(0.026)\end{array}$ & $\begin{array}{l}0.041^{* *} \\
(0.019)\end{array}$ & $\begin{array}{l}0.046^{* * *} \\
(0.015)\end{array}$ & $\begin{array}{l}0.036 * * * \\
(0.013)\end{array}$ & $\begin{array}{l}0.032 * * * \\
(0.012)\end{array}$ & $\begin{array}{l}0.035^{* * *} \\
(0.011)\end{array}$ & $\begin{array}{l}0.042^{* *} \\
(0.018)\end{array}$ \\
\hline Graduate degree & $\begin{array}{r}0.025 \\
(0.018)\end{array}$ & $\begin{array}{c}0.026 * \\
(0.013)\end{array}$ & $\begin{array}{l}0.031^{* * *} \\
(0.011)\end{array}$ & $\begin{array}{r}0.013 \\
(0.010)\end{array}$ & $\begin{array}{r}0.008 \\
(0.009)\end{array}$ & $\begin{array}{r}0.009 \\
(0.008)\end{array}$ & $\begin{array}{l}0.027 * * \\
(0.012)\end{array}$ \\
\hline $\begin{array}{l}\text { N (1098-T attendance data) } \\
\text { N (NSC degree completion) }\end{array}$ & $\begin{array}{c}10,522 \\
6,569\end{array}$ & $\begin{array}{l}21,063 \\
13,075\end{array}$ & $\begin{array}{l}31,500 \\
19,462\end{array}$ & $\begin{array}{l}41,499 \\
25,511\end{array}$ & $\begin{array}{l}51,815 \\
31,702\end{array}$ & $\begin{array}{l}59,698 \\
36,273\end{array}$ & $\begin{array}{l}X \\
X\end{array}$ \\
\hline \multicolumn{8}{|l|}{ Income Threshold } \\
\hline Bandwidth & $\$ 2,500$ & $\$ 5,000$ & $\$ 7,500$ & $\$ 10,000$ & $\$ 15,000$ & $\$ 20,000$ & CCT \\
\hline Receives Cal Grant & $\begin{array}{c}0.431 * * * \\
(0.023)\end{array}$ & $\begin{array}{c}0.400 * * * \\
(0.017)\end{array}$ & $\begin{array}{c}0.423 * * * \\
(0.013)\end{array}$ & $\begin{array}{c}0.420 * * * \\
(0.012)\end{array}$ & $\begin{array}{c}0.445^{* * *} \\
(0.009)\end{array}$ & $\begin{array}{c}0.467 * * * \\
(0.008)\end{array}$ & $\begin{array}{c}0.405^{* * *} \\
(0.016)\end{array}$ \\
\hline Cal Grant payment & $\begin{array}{c}8,287.273^{* * *} \\
(582.005)\end{array}$ & $\begin{array}{c}7,878.043^{* * *} \\
(409.200)\end{array}$ & $\begin{array}{c}8,022.470 * * * \\
\quad(332.918)\end{array}$ & $\begin{array}{c}8,115.300 * * * \\
\quad(286.167)\end{array}$ & $\begin{array}{c}8,552.997 * * * \\
\quad(229.716)\end{array}$ & $\begin{array}{c}\text { 8,722.359*** } \\
\quad(197.062)\end{array}$ & $\begin{array}{c}7,826.547 * * * \\
(413.768)\end{array}$ \\
\hline Ever attends & $\begin{array}{c}-0.004 \\
(0.007)\end{array}$ & $\begin{array}{l}-0.000 \\
(0.005)\end{array}$ & $\begin{array}{c}0.000 \\
(0.004)\end{array}$ & $\begin{array}{l}-0.001 \\
(0.003)\end{array}$ & $\begin{array}{c}0.004 \\
(0.003)\end{array}$ & $\begin{array}{c}0.002 \\
(0.002)\end{array}$ & $\begin{array}{l}-0.004 \\
(0.005)\end{array}$ \\
\hline CA Community College & $\begin{array}{l}-0.003 \\
(0.026)\end{array}$ & $\begin{array}{l}-0.011 \\
(0.018)\end{array}$ & $\begin{array}{c}-0.032 * * \\
(0.015)\end{array}$ & $\begin{array}{c}-0.029 * * \\
(0.013)\end{array}$ & $\begin{array}{l}-0.016 \\
(0.011)\end{array}$ & $\begin{array}{c}-0.023^{* *} \\
(0.009)\end{array}$ & $\begin{array}{l}-0.012 \\
(0.018)\end{array}$ \\
\hline CA Four-Year Public & $\begin{array}{c}-0.081^{* * *} \\
(0.027)\end{array}$ & $\begin{array}{c}-0.054^{* * *} \\
(0.020)\end{array}$ & $\begin{array}{c}-0.045^{* * *} \\
(0.016)\end{array}$ & $\begin{array}{c}-0.046^{* * *} \\
(0.014)\end{array}$ & $\begin{array}{c}-0.039 * * * \\
(0.011)\end{array}$ & $\begin{array}{c}-0.036 * * * \\
(0.010)\end{array}$ & $\begin{array}{c}-0.094 * * * \\
(0.025)\end{array}$ \\
\hline CA Private & $\begin{array}{c}0.057 * * \\
(0.024)\end{array}$ & $\begin{array}{c}0.050 * * * \\
(0.017)\end{array}$ & $\begin{array}{c}0.053 * * * \\
(0.014)\end{array}$ & $\begin{array}{c}0.056 * * * \\
(0.012)\end{array}$ & $\begin{array}{c}0.058 * * * \\
(0.010)\end{array}$ & $\begin{array}{c}0.054^{* * *} \\
(0.009)\end{array}$ & $\begin{array}{c}0.053^{* * *} \\
(0.017)\end{array}$ \\
\hline Bachelor's degree & $\begin{array}{r}-0.035 \\
(0.038)\end{array}$ & $\begin{array}{r}0.005 \\
(0.027)\end{array}$ & $\begin{array}{r}0.027 \\
(0.022)\end{array}$ & $\begin{array}{r}0.030 \\
(0.019)\end{array}$ & $\begin{array}{l}0.032 * * \\
(0.016)\end{array}$ & $\begin{array}{c}0.027^{*} \\
(0.014)\end{array}$ & $\begin{array}{r}0.005 \\
(0.029)\end{array}$ \\
\hline Graduate degree & $\begin{array}{r}0.030 \\
(0.034)\end{array}$ & $\begin{array}{r}0.040 \\
(0.025)\end{array}$ & $\begin{array}{r}0.029 \\
(0.020)\end{array}$ & $\begin{array}{c}0.029 * \\
(0.017)\end{array}$ & $\begin{array}{r}0.010 \\
(0.014)\end{array}$ & $\begin{array}{r}0.011 \\
(0.013)\end{array}$ & $\begin{array}{r}0.037 \\
(0.026)\end{array}$ \\
\hline N (1098-T attendance data) & 4,629 & 9,094 & 13,549 & 18,097 & 27,299 & 36,266 & $\mathrm{X}$ \\
\hline $\mathrm{N}$ (NSC degree completion) & 2,368 & 4,577 & 6,837 & 9,083 & 13,645 & 18,144 & $\mathrm{X}$ \\
\hline
\end{tabular}

Notes. This table provides estimates for the effect of Cal Grant eligibility on college attedance and degree attainment outcomes, varying the bandwidth of students that are inclucded in the estimates. All regressions include student age, parental education, parental marital status, citizen status, and year-by-family size fixed effects. A linear function of the running variable and a uniform kernel are used. Standard errors are clustered by GPA for GPA threshold regressions and are heteroskedasticity-robust in income threshold regressions. NSC regressions only include individuals who listed NSC-covered schools on their FAFSA. CCT regressions use an outcome-specific bandwidth, which varies in size.

${ }^{*} \mathrm{p}<0.1,{ }^{* *} \mathrm{p}<0.05,{ }^{* * *} \mathrm{p}<0.01$. 
Appendix Table A5. Robustness of Educational Attainment Results to Covariates and Functional Form

\begin{tabular}{|c|c|c|c|c|c|c|c|c|}
\hline & (1) & (2) & (3) & (4) & (5) & (6) & (7) & (8) \\
\hline Functional Form & Linear & Quad & Quad & Quad & Quad & Quad & Quad & Quad \\
\hline Covariates & $\mathrm{N}$ & $\mathrm{Y}$ & $\mathrm{Y}$ & $\mathrm{Y}$ & $\mathrm{Y}$ & $\mathrm{Y}$ & $\mathrm{Y}$ & $\mathrm{Y}$ \\
\hline \multicolumn{9}{|l|}{ GPA Threshold } \\
\hline Bandwidth & 0.3 & 0.1 & 0.2 & 0.3 & 0.4 & 0.5 & 0.6 & CCT \\
\hline Ever attends & $\begin{array}{c}0.005 \\
(0.005)\end{array}$ & $\begin{array}{c}0.004 \\
(0.016)\end{array}$ & $\begin{array}{l}-0.003 \\
(0.010)\end{array}$ & $\begin{array}{c}-0.002 \\
(0.008)\end{array}$ & $\begin{array}{c}0.002 \\
(0.006)\end{array}$ & $\begin{array}{c}-0.001 \\
(0.004)\end{array}$ & $\begin{array}{l}-0.001 \\
(0.003)\end{array}$ & $\begin{array}{l}-0.003 \\
(0.012)\end{array}$ \\
\hline CA Community College & $\begin{array}{c}-0.012 \\
(0.011)\end{array}$ & $\begin{array}{c}-0.032 * * \\
(0.012)\end{array}$ & $\begin{array}{c}-0.034^{* *} \\
(0.014)\end{array}$ & $\begin{array}{c}-0.031^{* *} \\
(0.012)\end{array}$ & $\begin{array}{c}-0.019 * \\
(0.011)\end{array}$ & $\begin{array}{c}-0.009 \\
(0.009)\end{array}$ & $\begin{array}{c}-0.001 \\
(0.007)\end{array}$ & $\begin{array}{c}-0.038 * * * \\
(0.012)\end{array}$ \\
\hline CA Four-Year Public & $\begin{array}{c}0.001 \\
(0.013)\end{array}$ & $\begin{array}{c}0.015 \\
(0.029)\end{array}$ & $\begin{array}{c}0.017 \\
(0.023)\end{array}$ & $\begin{array}{c}0.011 \\
(0.018)\end{array}$ & $\begin{array}{c}0.010 \\
(0.015)\end{array}$ & $\begin{array}{c}0.004 \\
(0.009)\end{array}$ & $\begin{array}{l}-0.007 \\
(0.008)\end{array}$ & $\begin{array}{c}0.013 \\
(0.027)\end{array}$ \\
\hline CA Private & $\begin{array}{c}0.003 \\
(0.007)\end{array}$ & $\begin{array}{c}-0.002 \\
(0.010)\end{array}$ & $\begin{array}{c}-0.005 \\
(0.009)\end{array}$ & $\begin{array}{c}-0.006 \\
(0.009)\end{array}$ & $\begin{array}{c}-0.007 \\
(0.008)\end{array}$ & $\begin{array}{c}-0.005 \\
(0.007)\end{array}$ & $\begin{array}{c}0.008 \\
(0.006)\end{array}$ & $\begin{array}{c}0.002 \\
(0.010)\end{array}$ \\
\hline Bachelor's Degree & $\begin{array}{l}0.045^{* * *} \\
(0.015)\end{array}$ & $\begin{array}{r}0.002 \\
(0.021)\end{array}$ & $\begin{array}{r}0.047 \\
(0.029)\end{array}$ & $\begin{array}{r}0.040 \\
(0.025)\end{array}$ & $\begin{array}{l}0.045^{* *} \\
(0.020)\end{array}$ & $\begin{array}{l}0.039 * * \\
(0.018)\end{array}$ & $\begin{array}{l}0.033^{* *} \\
(0.016)\end{array}$ & $\begin{array}{r}0.044 \\
(0.027)\end{array}$ \\
\hline Graduate Degree & $\begin{array}{l}0.030 * * * \\
(0.011)\end{array}$ & $\begin{array}{r}-0.021 \\
(0.017)\end{array}$ & $\begin{array}{r}0.026 \\
(0.018)\end{array}$ & $\begin{array}{r}0.025 \\
(0.016)\end{array}$ & $\begin{array}{l}0.038 * * \\
(0.015)\end{array}$ & $\begin{array}{l}0.026 * * \\
(0.013)\end{array}$ & $\begin{array}{r}0.018 \\
(0.012)\end{array}$ & $\begin{array}{r}0.024 \\
(0.017)\end{array}$ \\
\hline $\begin{array}{l}\text { N (1098-T attendance data) } \\
\text { N (NSC degree completion) }\end{array}$ & $\begin{array}{l}31,500 \\
19,462\end{array}$ & $\begin{array}{c}10,522 \\
6,569\end{array}$ & $\begin{array}{l}21,063 \\
13,075\end{array}$ & $\begin{array}{l}31,500 \\
19,462\end{array}$ & $\begin{array}{l}41,499 \\
25,511\end{array}$ & $\begin{array}{l}51,815 \\
31,702\end{array}$ & $\begin{array}{l}59,698 \\
36,273\end{array}$ & $\begin{array}{l}X \\
X\end{array}$ \\
\hline \multicolumn{9}{|l|}{ Income Threshold } \\
\hline Bandwidth & $\$ 10,000$ & $\$ 2,500$ & $\$ 5,000$ & $\$ 7,500$ & $\$ 10,000$ & $\$ 15,000$ & $\$ 20,000$ & CCT \\
\hline Ever attends & $\begin{array}{l}-0.001 \\
(0.003)\end{array}$ & $\begin{array}{l}-0.004 \\
(0.009)\end{array}$ & $\begin{array}{l}-0.004 \\
(0.006)\end{array}$ & $\begin{array}{l}-0.005 \\
(0.005)\end{array}$ & $\begin{array}{l}-0.003 \\
(0.004)\end{array}$ & $\begin{array}{l}-0.000 \\
(0.004)\end{array}$ & $\begin{array}{c}0.003 \\
(0.003)\end{array}$ & $\begin{array}{l}-0.000 \\
(0.006)\end{array}$ \\
\hline CA Community College & $\begin{array}{c}-0.031 * * \\
(0.013)\end{array}$ & $\begin{array}{c}0.001 \\
(0.033)\end{array}$ & $\begin{array}{l}-0.008 \\
(0.023)\end{array}$ & $\begin{array}{l}-0.008 \\
(0.019)\end{array}$ & $\begin{array}{l}-0.023 \\
(0.016)\end{array}$ & $\begin{array}{c}-0.027 * * \\
(0.013)\end{array}$ & $\begin{array}{c}-0.024 * * \\
(0.012)\end{array}$ & $\begin{array}{l}-0.006 \\
(0.023)\end{array}$ \\
\hline CA Four-Year Public & $\begin{array}{c}-0.047 * * * \\
(0.014)\end{array}$ & $\begin{array}{l}-0.068 * \\
(0.035)\end{array}$ & $\begin{array}{l}-0.049 * * \\
(0.025)\end{array}$ & $\begin{array}{c}-0.062 * * * \\
(0.020)\end{array}$ & $\begin{array}{c}-0.055^{* * *} \\
(0.018)\end{array}$ & $\begin{array}{c}-0.041 * * * \\
(0.014)\end{array}$ & $\begin{array}{c}-0.038 * * * \\
(0.013)\end{array}$ & $\begin{array}{c}-0.068 * * \\
(0.032)\end{array}$ \\
\hline CA Private & $\begin{array}{c}0.057 * * * \\
(0.012)\end{array}$ & $\begin{array}{c}0.047 \\
(0.031)\end{array}$ & $\begin{array}{c}0.047 * * \\
(0.022)\end{array}$ & $\begin{array}{c}0.056 * * * \\
(0.018)\end{array}$ & $\begin{array}{c}0.058 * * * \\
(0.016)\end{array}$ & $\begin{array}{c}0.058 * * * \\
(0.013)\end{array}$ & $\begin{array}{c}0.056 * * * \\
(0.011)\end{array}$ & $\begin{array}{c}0.047 * * \\
(0.022)\end{array}$ \\
\hline Bachelor's Degree & $\begin{array}{r}0.030 \\
(0.020)\end{array}$ & $\begin{array}{c}-0.047 \\
(0.055)\end{array}$ & $\begin{array}{r}-0.032 \\
(0.040)\end{array}$ & $\begin{array}{c}-0.017 \\
(0.033)\end{array}$ & $\begin{array}{r}0.011 \\
(0.029)\end{array}$ & $\begin{array}{r}0.028 \\
(0.024)\end{array}$ & $\begin{array}{c}0.032 \\
(0.021)\end{array}$ & $\begin{array}{r}-0.053 \\
(0.042)\end{array}$ \\
\hline Graduate Degree & $\begin{array}{c}0.030 * \\
(0.018)\end{array}$ & $\begin{array}{c}0.017 \\
(0.051)\end{array}$ & $\begin{array}{r}0.016 \\
(0.036)\end{array}$ & $\begin{array}{c}0.037 \\
(0.030)\end{array}$ & $\begin{array}{r}0.039 \\
(0.026)\end{array}$ & $\begin{array}{l}0.048 * * \\
(0.021)\end{array}$ & $\begin{array}{r}0.029 \\
(0.019)\end{array}$ & $\begin{array}{r}0.014 \\
(0.038)\end{array}$ \\
\hline N (1098-T attendance data) & 18,097 & 4,629 & 9,094 & 13,549 & 18,097 & 27,299 & 36,266 & $\mathrm{X}$ \\
\hline N (NSC degree completion) & 9,083 & 2,368 & 4,577 & 6,837 & 9,083 & 13,645 & 18,144 & $\mathrm{X}$ \\
\hline
\end{tabular}

Notes. This table provides estimates for the effect of Cal Grant eligibility on college attedance and degree attainment outcomes. In column 1 , a linear function of the running variable and a uniform kernel are used. In columns 2-8, regressions include student age, parental education, parental marital status, citizen status, and year-byfamily size fixed effects, use a quadratic function of the running variable, and a uniform kernel. Standard errors are clustered by GPA for GPA threshold regressions and are heteroskedasticity-robust in income threshold regressions. NSC regressions only include individuals who listed NSC-covered schools on their FAFSA. CCT regressions use an outcome-specific bandwidth, which varies in size.

${ }^{*} \mathrm{p}<0.1,{ }^{* *} \mathrm{p}<0.05,{ }^{* * *} \mathrm{p}<0.01$. 
Appendix Table A6. Robustness of Educational Attainment Results to Triangular Kernel

\begin{tabular}{|c|c|c|c|c|c|c|c|}
\hline \multicolumn{8}{|l|}{ GPA Threshold } \\
\hline Bandwidth & 0.10 & 0.20 & 0.30 & 0.40 & 0.50 & 0.60 & ССТ \\
\hline Ever attends & $\begin{array}{c}0.001 \\
(0.011)\end{array}$ & $\begin{array}{c}0.001 \\
(0.007)\end{array}$ & $\begin{array}{c}0.002 \\
(0.005)\end{array}$ & $\begin{array}{c}0.003 \\
(0.004)\end{array}$ & $\begin{array}{c}0.004 \\
(0.004)\end{array}$ & $\begin{array}{c}0.004 \\
(0.004)\end{array}$ & $\begin{array}{c}0.001 \\
(0.012)\end{array}$ \\
\hline CA Community College & $\begin{array}{c}-0.032 * * * \\
(0.010)\end{array}$ & $\begin{array}{c}-0.029 * * * \\
(0.010)\end{array}$ & $\begin{array}{c}-0.019 * * \\
(0.010)\end{array}$ & $\begin{array}{c}-0.016^{*} \\
(0.009)\end{array}$ & $\begin{array}{l}-0.014 \\
(0.009)\end{array}$ & $\begin{array}{c}-0.015^{*} \\
(0.008)\end{array}$ & $\begin{array}{c}-0.036 * * * \\
(0.010)\end{array}$ \\
\hline CA Four-Year Public & $\begin{array}{c}0.004 \\
(0.023)\end{array}$ & $\begin{array}{c}0.009 \\
(0.016)\end{array}$ & $\begin{array}{c}0.004 \\
(0.013)\end{array}$ & $\begin{array}{c}0.002 \\
(0.011)\end{array}$ & $\begin{array}{c}0.000 \\
(0.010)\end{array}$ & $\begin{array}{c}-0.000 \\
(0.010)\end{array}$ & $\begin{array}{c}0.003 \\
(0.025)\end{array}$ \\
\hline CA Private & $\begin{array}{c}0.002 \\
(0.008)\end{array}$ & $\begin{array}{c}0.001 \\
(0.008)\end{array}$ & $\begin{array}{c}0.000 \\
(0.007)\end{array}$ & $\begin{array}{c}0.004 \\
(0.006)\end{array}$ & $\begin{array}{c}0.007 \\
(0.006)\end{array}$ & $\begin{array}{l}0.010 * \\
(0.005)\end{array}$ & $\begin{array}{c}-0.004 \\
(0.008)\end{array}$ \\
\hline Bachelor's Degree & $\begin{array}{r}0.021 \\
(0.023)\end{array}$ & $\begin{array}{l}0.044^{* *} \\
(0.022)\end{array}$ & $\begin{array}{l}0.043^{* *} \\
(0.017)\end{array}$ & $\begin{array}{l}0.039 * * * \\
(0.015)\end{array}$ & $\begin{array}{l}0.035^{* * *} \\
(0.013)\end{array}$ & $\begin{array}{l}0.034^{* * *} \\
(0.012)\end{array}$ & $\begin{array}{l}0.044^{* *} \\
(0.021)\end{array}$ \\
\hline Graduate Degree & $\begin{array}{r}0.010 \\
(0.016)\end{array}$ & $\begin{array}{c}0.026 * \\
(0.014)\end{array}$ & $\begin{array}{l}0.028^{* *} \\
(0.012)\end{array}$ & $\begin{array}{l}0.023^{* *} \\
(0.010)\end{array}$ & $\begin{array}{r}0.015 \\
(0.009)\end{array}$ & $\begin{array}{r}0.013 \\
(0.009)\end{array}$ & $\begin{array}{c}0.027 * \\
(0.014)\end{array}$ \\
\hline $\begin{array}{l}\text { N (1098-T attendance data) } \\
\text { N (NSC degree completion) }\end{array}$ & $\begin{array}{c}10,522 \\
6,569\end{array}$ & $\begin{array}{l}21,063 \\
13,075\end{array}$ & $\begin{array}{l}31,500 \\
19,462\end{array}$ & $\begin{array}{l}41,499 \\
25,511\end{array}$ & $\begin{array}{l}51,815 \\
31,702\end{array}$ & $\begin{array}{l}59,698 \\
36,273\end{array}$ & $\begin{array}{l}X \\
X\end{array}$ \\
\hline \multicolumn{8}{|l|}{ Income Threshold } \\
\hline Bandwidth & $\$ 2,500$ & $\$ 5,000$ & $\$ 10,000$ & $\$ 15,000$ & $\$ 20,000$ & $\$ 25,000$ & CCT \\
\hline Ever attends & $\begin{array}{l}-0.006 \\
(0.007)\end{array}$ & $\begin{array}{c}-0.003 \\
(0.005)\end{array}$ & $\begin{array}{c}-0.001 \\
(0.004)\end{array}$ & $\begin{array}{c}0.001 \\
(0.003)\end{array}$ & $\begin{array}{c}0.002 \\
(0.003)\end{array}$ & $\begin{array}{c}0.002 \\
(0.002)\end{array}$ & $\begin{array}{c}-0.003 \\
(0.006)\end{array}$ \\
\hline CA Community College & $\begin{array}{l}-0.009 \\
(0.029)\end{array}$ & $\begin{array}{c}-0.004 \\
(0.020)\end{array}$ & $\begin{array}{c}-0.024^{*} \\
(0.014)\end{array}$ & $\begin{array}{c}-0.024^{* *} \\
(0.012)\end{array}$ & $\begin{array}{c}-0.023^{* *} \\
(0.010)\end{array}$ & $\begin{array}{c}-0.024^{* * *} \\
(0.009)\end{array}$ & $\begin{array}{c}-0.008 \\
(0.023)\end{array}$ \\
\hline CA Four-Year Public & $\begin{array}{c}-0.081^{* * *} \\
(0.030)\end{array}$ & $\begin{array}{c}-0.066^{* * *} \\
(0.021)\end{array}$ & $\begin{array}{c}-0.048 * * * \\
(0.015)\end{array}$ & $\begin{array}{c}-0.043^{* * *} \\
(0.012)\end{array}$ & $\begin{array}{c}-0.039 * * * \\
(0.011)\end{array}$ & $\begin{array}{c}-0.038 * * * \\
(0.010)\end{array}$ & $\begin{array}{c}-0.078 * * \\
(0.031)\end{array}$ \\
\hline CA Private & $\begin{array}{c}0.063 * * \\
(0.026)\end{array}$ & $\begin{array}{c}0.056 * * * \\
(0.019)\end{array}$ & $\begin{array}{c}0.054 * * * \\
(0.013)\end{array}$ & $\begin{array}{c}0.059 * * * \\
(0.011)\end{array}$ & $\begin{array}{c}0.057 * * * \\
(0.010)\end{array}$ & $\begin{array}{c}0.057 * * * \\
(0.009)\end{array}$ & $\begin{array}{c}0.050 * * \\
(0.020)\end{array}$ \\
\hline Bachelor's Degree & $\begin{array}{c}-0.047 \\
(0.055)\end{array}$ & $\begin{array}{r}-0.010 \\
(0.030)\end{array}$ & $\begin{array}{r}0.009 \\
(0.024)\end{array}$ & $\begin{array}{r}0.022 \\
(0.021)\end{array}$ & $\begin{array}{c}0.030 * \\
(0.017)\end{array}$ & $\begin{array}{c}0.030 * \\
(0.015)\end{array}$ & $\begin{array}{r}-0.053 \\
(0.042)\end{array}$ \\
\hline Graduate Degree & $\begin{array}{r}0.022 \\
(0.038)\end{array}$ & $\begin{array}{r}0.031 \\
(0.027)\end{array}$ & $\begin{array}{r}0.033 \\
(0.022)\end{array}$ & $\begin{array}{c}0.033^{*} \\
(0.019)\end{array}$ & $\begin{array}{r}0.025 \\
(0.016)\end{array}$ & $\begin{array}{r}0.018 \\
(0.014)\end{array}$ & $\begin{array}{c}0.014 \\
(0.038)\end{array}$ \\
\hline $\begin{array}{l}\text { N (1098-T attendance data) } \\
\text { N (NSC degree completion) }\end{array}$ & $\begin{array}{l}4,629 \\
2368\end{array}$ & $\begin{array}{l}9,094 \\
4,577\end{array}$ & $\begin{array}{c}13,549 \\
6,837\end{array}$ & $\begin{array}{c}18,097 \\
9,083\end{array}$ & $\begin{array}{l}27,299 \\
13,645\end{array}$ & $\begin{array}{l}36,266 \\
18,144\end{array}$ & $\begin{array}{l}X \\
X\end{array}$ \\
\hline
\end{tabular}

Notes. This table provides estimates for the effect of Cal Grant eligibility on college attedance and degree attainment outcomes. All regressions include student age, parental education, parental marital status, citizen status, and year-by-family size fixed effects. A linear function of the running variable and a triangular kernel are used. Standard errors are clustered by GPA for GPA threshold regressions and are heteroskedasticity-robust in income threshold regressions. NSC regressions only include individuals who listed NSC-covered schools on their FAFSA. CCT regressions use an outcome-specific bandwidth, which varies in size. 
Appendix Table A7. Robustness of Income and Demographic Outcomes to Varying Bandwidths

\begin{tabular}{|c|c|c|c|c|c|c|c|}
\hline GPA Threshold & & & & & & & \\
\hline Bandwidth & 0.1 & 0.2 & 0.3 & 0.4 & 0.5 & 0.6 & СCT \\
\hline Filed a tax return & $\begin{array}{c}0.002 \\
(0.009)\end{array}$ & $\begin{array}{c}0.002 \\
(0.007)\end{array}$ & $\begin{array}{c}0.004 \\
(0.006)\end{array}$ & $\begin{array}{l}-0.000 \\
(0.005)\end{array}$ & $\begin{array}{l}-0.003 \\
(0.003)\end{array}$ & $\begin{array}{l}-0.001 \\
(0.002)\end{array}$ & $\begin{array}{c}0.001 \\
(0.008)\end{array}$ \\
\hline Log labor income & $\begin{array}{c}0.084^{* * *} \\
(0.019)\end{array}$ & $\begin{array}{c}0.051^{* *} \\
(0.020)\end{array}$ & $\begin{array}{c}0.055^{* * *} \\
(0.018)\end{array}$ & $\begin{array}{c}0.060^{* * *} \\
(0.015)\end{array}$ & $\begin{array}{l}0.018^{*} \\
(0.010)\end{array}$ & $\begin{array}{l}0.018^{*} \\
(0.009)\end{array}$ & $\begin{array}{c}0.057^{* * *} \\
(0.020)\end{array}$ \\
\hline Income percentile & $\begin{array}{c}0.865 \\
(0.556)\end{array}$ & $\begin{array}{l}1.153^{*} \\
(0.570)\end{array}$ & $\begin{array}{c}1.344^{* * *} \\
(0.497)\end{array}$ & $\begin{array}{c}1.002^{* *} \\
(0.407)\end{array}$ & $\begin{array}{c}0.439 \\
(0.288)\end{array}$ & $\begin{array}{c}0.301 \\
(0.241)\end{array}$ & $\begin{array}{c}0.865 \\
(0.556)\end{array}$ \\
\hline Log household size-adjusted AGI & $\begin{array}{c}0.005 \\
(0.024)\end{array}$ & $\begin{array}{c}0.013 \\
(0.018)\end{array}$ & $\begin{array}{l}0.031^{*} \\
(0.016)\end{array}$ & $\begin{array}{c}0.029^{* *} \\
(0.014)\end{array}$ & $\begin{array}{c}0.020^{* *} \\
(0.010)\end{array}$ & $\begin{array}{c}0.018^{* *} \\
(0.008)\end{array}$ & $\begin{array}{c}0.005 \\
(0.024)\end{array}$ \\
\hline Live in CA & $\begin{array}{l}-0.009 \\
(0.010)\end{array}$ & $\begin{array}{l}-0.003 \\
(0.007)\end{array}$ & $\begin{array}{l}-0.004 \\
(0.007)\end{array}$ & $\begin{array}{l}-0.001 \\
(0.006)\end{array}$ & $\begin{array}{l}-0.004 \\
(0.005)\end{array}$ & $\begin{array}{l}-0.005 \\
(0.004)\end{array}$ & $\begin{array}{l}-0.004 \\
(0.009)\end{array}$ \\
\hline Married & $\begin{array}{l}-0.022 \\
(0.019)\end{array}$ & $\begin{array}{l}-0.014 \\
(0.015)\end{array}$ & $\begin{array}{l}-0.015 \\
(0.012)\end{array}$ & $\begin{array}{l}-0.006 \\
(0.010)\end{array}$ & $\begin{array}{c}0.006 \\
(0.006)\end{array}$ & $\begin{array}{c}0.005 \\
(0.005)\end{array}$ & $\begin{array}{l}-0.020 \\
(0.019)\end{array}$ \\
\hline Has kids & $\begin{array}{c}0.000 \\
(0.011)\end{array}$ & $\begin{array}{l}-0.009 \\
(0.008)\end{array}$ & $\begin{array}{c}-0.023^{* * * *} \\
(0.008)\end{array}$ & $\begin{array}{c}-0.017^{* *} \\
(0.007)\end{array}$ & $\begin{array}{l}-0.003 \\
(0.005)\end{array}$ & $\begin{array}{l}-0.000 \\
(0.005)\end{array}$ & $\begin{array}{c}0.000 \\
(0.011)\end{array}$ \\
\hline $\mathrm{N}$ & 52,610 & 105,315 & 157,500 & 207,495 & 259,075 & 298,490 & $\mathrm{X}$ \\
\hline Income Threshold & & & & & & & \\
\hline Bandwidth & $\$ 2,500$ & $\$ 5,000$ & $\$ 7,500$ & $\$ 10,000$ & $\$ 15,000$ & $\$ 20,000$ & CCT \\
\hline Filed a tax return & $\begin{array}{c}-0.020^{* * *} \\
(0.006)\end{array}$ & $\begin{array}{c}-0.016^{* * *} \\
(0.004)\end{array}$ & $\begin{array}{c}-0.009 * * * \\
(0.003)\end{array}$ & $\begin{array}{l}-0.006 * \\
(0.003)\end{array}$ & $\begin{array}{l}-0.002 \\
(0.002)\end{array}$ & $\begin{array}{l}-0.003 \\
(0.002)\end{array}$ & $\begin{array}{c}-0.017 * * * \\
(0.004)\end{array}$ \\
\hline Log labor income & $\begin{array}{l}-0.037 \\
(0.030)\end{array}$ & $\begin{array}{c}-0.071^{* * * *} \\
(0.021)\end{array}$ & $\begin{array}{c}-0.054^{* * * *} \\
(0.018)\end{array}$ & $\begin{array}{l}-0.020 \\
(0.015)\end{array}$ & $\begin{array}{l}-0.015 \\
(0.013)\end{array}$ & $\begin{array}{c}-0.024^{* *} \\
(0.011)\end{array}$ & $\begin{array}{c}-0.063^{* * *} \\
(0.023)\end{array}$ \\
\hline Income percentile & $\begin{array}{c}-1.593^{* *} \\
(0.726)\end{array}$ & $\begin{array}{c}-2.289 * * * \\
(0.516)\end{array}$ & $\begin{array}{c}-1.591 * * * \\
(0.422)\end{array}$ & $\begin{array}{l}-0.468 \\
(0.367)\end{array}$ & $\begin{array}{l}-0.460 \\
(0.300)\end{array}$ & $\begin{array}{c}-0.667^{* *} \\
(0.262)\end{array}$ & $\begin{array}{c}-2.350 * * * \\
(0.596)\end{array}$ \\
\hline Log household size-adjusted AGI & $\begin{array}{l}-0.003 \\
(0.024)\end{array}$ & $\begin{array}{c}-0.037 * * \\
(0.017)\end{array}$ & $\begin{array}{c}-0.036^{* * *} \\
(0.014)\end{array}$ & $\begin{array}{l}-0.005 \\
(0.012)\end{array}$ & $\begin{array}{l}-0.013 \\
(0.010)\end{array}$ & $\begin{array}{c}-0.022 * * \\
(0.009)\end{array}$ & $\begin{array}{l}-0.027 \\
(0.018)\end{array}$ \\
\hline Live in CA & $\begin{array}{c}0.005 \\
(0.011)\end{array}$ & $\begin{array}{c}0.011 \\
(0.008)\end{array}$ & $\begin{array}{c}0.017^{* * *} \\
(0.006)\end{array}$ & $\begin{array}{c}0.024 * * * \\
(0.005)\end{array}$ & $\begin{array}{c}0.014 * * * \\
(0.004)\end{array}$ & $\begin{array}{c}0.010^{* * *} \\
(0.004)\end{array}$ & $\begin{array}{c}0.010 \\
(0.010)\end{array}$ \\
\hline Married & $\begin{array}{l}-0.023 * \\
(0.013)\end{array}$ & $\begin{array}{l}-0.006 \\
(0.010)\end{array}$ & $\begin{array}{c}0.002 \\
(0.008)\end{array}$ & $\begin{array}{c}0.005 \\
(0.007)\end{array}$ & $\begin{array}{c}0.009 \\
(0.006)\end{array}$ & $\begin{array}{c}0.011^{* *} \\
(0.005)\end{array}$ & $\begin{array}{l}-0.001 \\
(0.010)\end{array}$ \\
\hline Has kids & $\begin{array}{l}-0.016 \\
(0.012)\end{array}$ & $\begin{array}{c}0.007 \\
(0.009)\end{array}$ & $\begin{array}{c}0.009 \\
(0.007)\end{array}$ & $\begin{array}{c}0.003 \\
(0.006)\end{array}$ & $\begin{array}{c}0.007 \\
(0.005)\end{array}$ & $\begin{array}{c}0.007 \\
(0.004)\end{array}$ & $\begin{array}{c}0.008 \\
(0.007)\end{array}$ \\
\hline $\mathrm{N}$ & 23,145 & 45,470 & 67,745 & 90,485 & 136,495 & 181,330 & $\mathrm{X}$ \\
\hline
\end{tabular}

Notes. This table provides estimates for the effect of Cal Grant eligibility on income and demographic outcomes 10 through 14 years after application, varying the bandwidth of students that are inclucded in the estimates. All regressions include student age, parental education, parental marital status, citizen status, and year-by-family size fixed effects. A linear function of the running variable and a uniform kernel are used. Standard errors are clustered by GPA for GPA threshold regressions and are heteroskedasticity-robust in income threshold regressions. Number of observations reported for income and demographic outcomes correspond to the "filed a tax return" outcome variable. CCT regressions use an outcome-specific bandwidth, which varies in size.

$* \mathrm{p}<0.1, * * \mathrm{p}<0.05, * * * \mathrm{p}<0.01$. 
Appendix Table A8. Robustness of Income and Demographic Outcomes to Covariates and Functional Form

\begin{tabular}{|c|c|c|c|c|c|c|c|c|}
\hline & $(1)$ & $(2)$ & $(3)$ & $(4)$ & $(5)$ & $(6)$ & $(7)$ & $(8)$ \\
\hline Functional Form & Linear & Quad & Quad & Quad & Quad & Quad & Quad & Quad \\
\hline Covariates & $\mathrm{N}$ & $\mathrm{Y}$ & $\mathrm{Y}$ & $\mathrm{Y}$ & $\mathrm{Y}$ & $\mathrm{Y}$ & $\mathrm{Y}$ & $\mathrm{Y}$ \\
\hline \multicolumn{9}{|l|}{ GPA Threshold } \\
\hline$\overline{\text { Bandwidth }}$ & 0.3 & 0.1 & 0.2 & 0.3 & 0.4 & 0.5 & 0.6 & СCT \\
\hline Filed a tax return & $\begin{array}{c}0.004 \\
(0.006)\end{array}$ & $\begin{array}{l}0.019 * \\
(0.010)\end{array}$ & $\begin{array}{c}0.001 \\
(0.009)\end{array}$ & $\begin{array}{l}-0.000 \\
(0.008)\end{array}$ & $\begin{array}{c}0.006 \\
(0.007)\end{array}$ & $\begin{array}{c}0.000 \\
(0.004)\end{array}$ & $\begin{array}{l}-0.001 \\
(0.003)\end{array}$ & $\begin{array}{c}0.003 \\
(0.009)\end{array}$ \\
\hline Log labor income & $\begin{array}{c}0.054^{* * *} \\
(0.018)\end{array}$ & $\begin{array}{c}0.099 * * * \\
(0.029)\end{array}$ & $\begin{array}{c}0.070^{* * *} \\
(0.023)\end{array}$ & $\begin{array}{c}0.055^{* *} \\
(0.022)\end{array}$ & $\begin{array}{c}0.058^{* * *} \\
(0.021)\end{array}$ & $\begin{array}{l}0.033^{*} \\
(0.018)\end{array}$ & $\begin{array}{c}0.028^{* *} \\
(0.014)\end{array}$ & $\begin{array}{c}0.104^{* * *} \\
(0.024)\end{array}$ \\
\hline Income percentile & $\begin{array}{c}1.303^{* *} \\
(0.515)\end{array}$ & $\begin{array}{c}1.184 \\
(0.692)\end{array}$ & $\begin{array}{c}0.578 \\
(0.597)\end{array}$ & $\begin{array}{c}0.876 \\
(0.607)\end{array}$ & $\begin{array}{l}1.535^{* *} \\
(0.604)\end{array}$ & $\begin{array}{c}0.713 \\
(0.512)\end{array}$ & $\begin{array}{l}0.717^{*} \\
(0.425)\end{array}$ & $\begin{array}{c}1.184 \\
(0.692)\end{array}$ \\
\hline Log household size-adjusted AGI & $\begin{array}{l}0.031^{*} \\
(0.016)\end{array}$ & $\begin{array}{c}1.184 \\
(0.692)\end{array}$ & $\begin{array}{c}0.578 \\
(0.597)\end{array}$ & $\begin{array}{c}0.876 \\
(0.607)\end{array}$ & $\begin{array}{l}1.535^{* *} \\
(0.604)\end{array}$ & $\begin{array}{c}0.713 \\
(0.512)\end{array}$ & $\begin{array}{l}0.717^{*} \\
(0.425)\end{array}$ & $\begin{array}{c}0.073 * * * \\
(0.017)\end{array}$ \\
\hline Live in CA & $\begin{array}{l}-0.004 \\
(0.007)\end{array}$ & $\begin{array}{c}0.008 \\
(0.011)\end{array}$ & $\begin{array}{l}-0.015 \\
(0.013)\end{array}$ & $\begin{array}{l}-0.007 \\
(0.009)\end{array}$ & $\begin{array}{l}-0.006 \\
(0.008)\end{array}$ & $\begin{array}{l}-0.010 \\
(0.007)\end{array}$ & $\begin{array}{c}-0.012^{* *} \\
(0.006)\end{array}$ & $\begin{array}{c}0.001 \\
(0.012)\end{array}$ \\
\hline Married & $\begin{array}{l}-0.014 \\
(0.012)\end{array}$ & $\begin{array}{l}-0.031^{*} \\
(0.016)\end{array}$ & $\begin{array}{l}-0.032 \\
(0.020)\end{array}$ & $\begin{array}{l}-0.022 \\
(0.018)\end{array}$ & $\begin{array}{l}-0.024 \\
(0.017)\end{array}$ & $\begin{array}{l}-0.006 \\
(0.010)\end{array}$ & $\begin{array}{c}0.009 \\
(0.008)\end{array}$ & $\begin{array}{l}-0.029 \\
(0.018)\end{array}$ \\
\hline Has kids & $\begin{array}{c}-0.023 * * * \\
(0.009)\end{array}$ & $\begin{array}{c}-0.027 * * * \\
(0.008)\end{array}$ & $\begin{array}{l}-0.018^{*} \\
(0.010)\end{array}$ & $\begin{array}{l}-0.011 \\
(0.009)\end{array}$ & $\begin{array}{c}-0.023^{* *} \\
(0.010)\end{array}$ & $\begin{array}{l}-0.010 \\
(0.007)\end{array}$ & $\begin{array}{l}-0.000 \\
(0.007)\end{array}$ & $\begin{array}{c}-0.027 * * * * \\
(0.008)\end{array}$ \\
\hline $\mathrm{N}$ & 157,500 & 52,610 & 105,315 & 157,500 & 207,495 & 259,075 & 298,490 & $\mathrm{X}$ \\
\hline \multicolumn{9}{|l|}{ Income Threshold } \\
\hline Bandwidth & $\$ 10,000$ & $\$ 2,500$ & $\$ 5,000$ & $\$ 7,500$ & $\$ 10,000$ & $\$ 15,000$ & $\$ 20,000$ & CCT \\
\hline Filed a tax return & $\begin{array}{l}-0.006 * \\
(0.003)\end{array}$ & $\begin{array}{c}-0.021^{* *} \\
(0.009)\end{array}$ & $\begin{array}{c}-0.027 * * * \\
(0.006)\end{array}$ & $\begin{array}{c}-0.025 * * * \\
(0.005)\end{array}$ & $\begin{array}{c}-0.019 * * * \\
(0.004)\end{array}$ & $\begin{array}{c}-0.012 * * * \\
(0.004)\end{array}$ & $\begin{array}{l}-0.004 \\
(0.003)\end{array}$ & $\begin{array}{c}-0.027 * * * * \\
(0.005)\end{array}$ \\
\hline Log labor income & $\begin{array}{l}-0.021 \\
(0.015)\end{array}$ & $\begin{array}{l}-0.081^{*} \\
(0.044)\end{array}$ & $\begin{array}{l}-0.045 \\
(0.032)\end{array}$ & $\begin{array}{c}-0.075^{* * * *} \\
(0.026)\end{array}$ & $\begin{array}{c}-0.081^{* * *} \\
(0.023)\end{array}$ & $\begin{array}{c}-0.037 * * \\
(0.019)\end{array}$ & $\begin{array}{l}-0.016 \\
(0.016)\end{array}$ & $\begin{array}{l}-0.056^{*} \\
(0.029)\end{array}$ \\
\hline Income percentile & $\begin{array}{l}-0.488 \\
(0.367)\end{array}$ & $\begin{array}{l}-2.074 * \\
(1.079)\end{array}$ & $\begin{array}{c}-2.303^{* * *} \\
(0.771)\end{array}$ & $\begin{array}{c}-2.571 * * * \\
(0.630)\end{array}$ & $\begin{array}{c}-2.619 * * * \\
(0.547)\end{array}$ & $\begin{array}{c}-1.127 * * \\
(0.448)\end{array}$ & $\begin{array}{l}-0.494 \\
(0.389)\end{array}$ & $\begin{array}{l}-0.922 \\
(0.758)\end{array}$ \\
\hline Log household size-adjusted AGI & $\begin{array}{c}-0.005 \\
(0.012)\end{array}$ & $\begin{array}{c}0.031 \\
(0.036)\end{array}$ & $\begin{array}{c}0.002 \\
(0.025)\end{array}$ & $\begin{array}{l}-0.028 \\
(0.020)\end{array}$ & $\begin{array}{c}-0.058 * * * \\
(0.018)\end{array}$ & $\begin{array}{l}-0.016 \\
(0.015)\end{array}$ & $\begin{array}{l}-0.009 \\
(0.013)\end{array}$ & $\begin{array}{l}-0.008 \\
(0.022)\end{array}$ \\
\hline Live in CA & $\begin{array}{c}0.022 * * * \\
(0.005)\end{array}$ & $\begin{array}{c}0.000 \\
(0.016)\end{array}$ & $\begin{array}{c}0.018 \\
(0.011)\end{array}$ & $\begin{array}{c}0.002 \\
(0.009)\end{array}$ & $\begin{array}{c}0.002 \\
(0.008)\end{array}$ & $\begin{array}{c}0.020 * * * \\
(0.007)\end{array}$ & $\begin{array}{c}0.023 * * * \\
(0.006)\end{array}$ & $\begin{array}{c}0.015 \\
(0.012)\end{array}$ \\
\hline Married & $\begin{array}{c}0.005 \\
(0.007)\end{array}$ & $\begin{array}{l}-0.026 \\
(0.020)\end{array}$ & $\begin{array}{l}-0.016 \\
(0.014)\end{array}$ & $\begin{array}{l}-0.004 \\
(0.012)\end{array}$ & $\begin{array}{l}-0.006 \\
(0.010)\end{array}$ & $\begin{array}{c}0.005 \\
(0.008)\end{array}$ & $\begin{array}{c}0.008 \\
(0.007)\end{array}$ & $\begin{array}{l}-0.012 \\
(0.013)\end{array}$ \\
\hline Has kids & $\begin{array}{c}0.002 \\
(0.006)\end{array}$ & $\begin{array}{l}-0.024 \\
(0.018)\end{array}$ & $\begin{array}{l}-0.004 \\
(0.013)\end{array}$ & $\begin{array}{c}0.012 \\
(0.011)\end{array}$ & $\begin{array}{c}0.008 \\
(0.009)\end{array}$ & $\begin{array}{c}0.006 \\
(0.008)\end{array}$ & $\begin{array}{c}0.009 \\
(0.007)\end{array}$ & $\begin{array}{c}0.008 \\
(0.009)\end{array}$ \\
\hline $\mathrm{N}$ & 90,485 & 23,145 & 45,470 & 67,745 & 90,485 & 136,495 & 181,330 & $\mathrm{X}$ \\
\hline
\end{tabular}


Appendix Table A9. Robustness of Income and Demographic Results to Triangular Kernel

\begin{tabular}{|c|c|c|c|c|c|c|c|}
\hline GPA Threshold & & & & & & & \\
\hline Bandwidth & 0.10 & 0.20 & 0.30 & 0.40 & 0.50 & 0.60 & ССТ \\
\hline Filed a tax return & $\begin{array}{l}0.009 \\
(0.008)\end{array}$ & $\begin{array}{l}0.002 \\
(0.007)\end{array}$ & $\begin{array}{l}0.003 \\
(0.006)\end{array}$ & $\begin{array}{l}0.002 \\
(0.005)\end{array}$ & $\begin{array}{l}0.000 \\
(0.004)\end{array}$ & $\begin{array}{l}-0.001 \\
(0.003)\end{array}$ & $\begin{array}{c}0.010 \\
(0.008)\end{array}$ \\
\hline Log labor income & $\begin{array}{l}0.090^{* * *} \\
(0.019)\end{array}$ & $\begin{array}{l}0.060^{* * *} \\
(0.018)\end{array}$ & $\begin{array}{l}0.056 * * * \\
(0.017)\end{array}$ & $\begin{array}{l}0.059 * * * \\
(0.016)\end{array}$ & $\begin{array}{l}0.042 * * * \\
(0.013)\end{array}$ & $\begin{array}{l}0.031 * * * \\
(0.011)\end{array}$ & $\begin{array}{c}0.108^{* * * *} \\
(0.022)\end{array}$ \\
\hline Income percentile & $\begin{array}{l}0.994 * \\
(0.478)\end{array}$ & $\begin{array}{l}1.006^{*} \\
(0.500)\end{array}$ & $\begin{array}{l}1.203^{* *} \\
(0.485)\end{array}$ & $\begin{array}{l}1.205^{* * *} \\
(0.436)\end{array}$ & $\begin{array}{l}0.807^{* *} \\
(0.342)\end{array}$ & $\begin{array}{l}0.593^{* *} \\
(0.282)\end{array}$ & $\begin{array}{c}1.225^{* *} \\
(0.589)\end{array}$ \\
\hline Log household size-adjusted AGI & $\begin{array}{l}0.029 \\
(0.019)\end{array}$ & $\begin{array}{l}0.012 \\
(0.019)\end{array}$ & $\begin{array}{l}0.024 \\
(0.017)\end{array}$ & $\begin{array}{l}0.027^{*} \\
(0.015)\end{array}$ & $\begin{array}{l}0.022 * \\
(0.011)\end{array}$ & $\begin{array}{l}0.021^{* *} \\
(0.009)\end{array}$ & $\begin{array}{c}0.064^{* * *} \\
(0.013)\end{array}$ \\
\hline Live in CA & $\begin{array}{l}-0.004 \\
(0.009)\end{array}$ & $\begin{array}{l}-0.007 \\
(0.008)\end{array}$ & $\begin{array}{l}-0.005 \\
(0.006)\end{array}$ & $\begin{array}{l}-0.003 \\
(0.006)\end{array}$ & $\begin{array}{l}-0.002 \\
(0.005)\end{array}$ & $\begin{array}{l}-0.003 \\
(0.004)\end{array}$ & $\begin{array}{c}0.001 \\
(0.010)\end{array}$ \\
\hline Married & $\begin{array}{l}-0.023 \\
(0.018)\end{array}$ & $\begin{array}{l}-0.020 \\
(0.016)\end{array}$ & $\begin{array}{l}-0.017 \\
(0.014)\end{array}$ & $\begin{array}{l}-0.013 \\
(0.011)\end{array}$ & $\begin{array}{l}-0.005 \\
(0.009)\end{array}$ & $\begin{array}{l}-0.000 \\
(0.007)\end{array}$ & $\begin{array}{c}-0.032 * * \\
(0.014)\end{array}$ \\
\hline Has kids & $\begin{array}{l}-0.008 \\
(0.009)\end{array}$ & $\begin{array}{l}-0.012 \\
(0.007)\end{array}$ & $\begin{array}{l}-0.018^{* *} \\
(0.007)\end{array}$ & $\begin{array}{l}-0.019 * * * \\
(0.007)\end{array}$ & $\begin{array}{l}-0.011^{* *} \\
(0.006)\end{array}$ & $\begin{array}{l}-0.006 \\
(0.005)\end{array}$ & $\begin{array}{c}-0.014^{*} \\
(0.008)\end{array}$ \\
\hline $\mathrm{N}$ & 52,610 & 105,315 & 157,500 & 207,495 & 253,860 & 298,490 & $\mathrm{X}$ \\
\hline Income Threshold & & & & & & & \\
\hline Bandwidth & $\$ 2,500$ & $\$ 5,000$ & $\$ 7,500$ & $\$ 10,000$ & $\$ 15,000$ & $\$ 20,000$ & ССТ \\
\hline Filed a tax return & $\begin{array}{c}-0.022 * * * \\
(0.006)\end{array}$ & $\begin{array}{c}-0.021 * * * \\
(0.004)\end{array}$ & $\begin{array}{c}-0.015 * * * \\
(0.004)\end{array}$ & $\begin{array}{c}-0.011^{* * *} \\
(0.003)\end{array}$ & $\begin{array}{c}-0.006 * * \\
(0.003)\end{array}$ & $\begin{array}{l}-0.004 \\
(0.002)\end{array}$ & $\begin{array}{c}-0.025^{* * *} \\
(0.005)\end{array}$ \\
\hline Log labor income & $\begin{array}{c}-0.055^{*} \\
(0.032)\end{array}$ & $\begin{array}{c}-0.061^{* * *} \\
(0.023)\end{array}$ & $\begin{array}{c}-0.062 * * * \\
(0.019)\end{array}$ & $\begin{array}{c}-0.045^{* * *} \\
(0.017)\end{array}$ & $\begin{array}{c}-0.024 * \\
(0.014)\end{array}$ & $\begin{array}{c}-0.021 * \\
(0.012)\end{array}$ & $\begin{array}{c}-0.048 * \\
(0.028)\end{array}$ \\
\hline Income percentile & $\begin{array}{c}-1.840^{* *} \\
(0.796)\end{array}$ & $\begin{array}{c}-2.296 * * * \\
(0.563)\end{array}$ & $\begin{array}{c}-1.979 * * * \\
(0.462)\end{array}$ & $\begin{array}{c}-1.346 * * * \\
(0.401)\end{array}$ & $\begin{array}{c}-0.723 * * \\
(0.328)\end{array}$ & $\begin{array}{c}-0.594 * * \\
(0.286)\end{array}$ & $\begin{array}{c}-1.694 * * \\
(0.706)\end{array}$ \\
\hline Log household size-adjusted AGI & $\begin{array}{c}0.011 \\
(0.026)\end{array}$ & $\begin{array}{l}-0.021 \\
(0.018)\end{array}$ & $\begin{array}{c}-0.033 * * \\
(0.015)\end{array}$ & $\begin{array}{c}-0.026 * * \\
(0.013)\end{array}$ & $\begin{array}{l}-0.015 \\
(0.011)\end{array}$ & $\begin{array}{l}-0.017 * \\
(0.009)\end{array}$ & $\begin{array}{l}-0.011 \\
(0.021)\end{array}$ \\
\hline Live in CA & $\begin{array}{c}0.004 \\
(0.012)\end{array}$ & $\begin{array}{l}0.014^{*} \\
(0.008)\end{array}$ & $\begin{array}{c}0.011 \\
(0.007)\end{array}$ & $\begin{array}{c}0.015^{* * *} \\
(0.006)\end{array}$ & $\begin{array}{c}0.016^{* * *} \\
(0.005)\end{array}$ & $\begin{array}{c}0.015^{* * *} \\
(0.004)\end{array}$ & $\begin{array}{c}0.010 \\
(0.011)\end{array}$ \\
\hline Married & $\begin{array}{l}-0.024 \\
(0.015)\end{array}$ & $\begin{array}{l}-0.011 \\
(0.010)\end{array}$ & $\begin{array}{l}-0.001 \\
(0.009)\end{array}$ & $\begin{array}{c}0.002 \\
(0.007)\end{array}$ & $\begin{array}{c}0.008 \\
(0.006)\end{array}$ & $\begin{array}{l}0.010^{*} \\
(0.005)\end{array}$ & $\begin{array}{l}-0.017 \\
(0.012)\end{array}$ \\
\hline Has kids & $\begin{array}{l}-0.021 \\
(0.013)\end{array}$ & $\begin{array}{c}0.002 \\
(0.010)\end{array}$ & $\begin{array}{c}0.010 \\
(0.008)\end{array}$ & $\begin{array}{c}0.005 \\
(0.007)\end{array}$ & $\begin{array}{c}0.006 \\
(0.006)\end{array}$ & $\begin{array}{c}0.008 \\
(0.005)\end{array}$ & $\begin{array}{c}0.009 \\
(0.008)\end{array}$ \\
\hline $\mathrm{N}$ & 22,800 & 45,315 & 67,450 & 90,310 & 136,310 & 181,190 & $\mathrm{X}$ \\
\hline
\end{tabular}

Notes. This table provides estimates for the effect of Cal Grant eligibility on income and demographic outcomes 10 through 14 years after application, varying the bandwidth of students that are inclucded in the estimates. All regressions include student age, parental education, parental marital status, citizen status, and year-by-family size fixed effects. A linear function of the running variable and a triangular kernel are used. Standard errors are clustered by GPA for GPA threshold regressions and are heteroskedasticity-robust in income threshold regressions. Number of observations reported for income and demographic outcomes correspond to the "filed a tax return" outcome variable. CCT regressions use an outcome-specific bandwidth, which varies in size. ${ }^{*} \mathrm{p}<0.1,{ }^{* *} \mathrm{p}<0.05,{ }^{* * *} \mathrm{p}<0.01$. 
Appendix Table A10: Educational Attainment by FAFSA preferences, NSC data

\begin{tabular}{|c|c|c|c|c|c|c|}
\hline & $\mathrm{N}$ & $\begin{array}{c}\text { (1) } \\
\text { Two-Year } \\
\text { Public }\end{array}$ & $\begin{array}{c}(2) \\
\text { Four-Year } \\
\text { Public }\end{array}$ & $\begin{array}{c}\text { (3) } \\
\text { Private }\end{array}$ & Bachelor & $\begin{array}{c}\text { (5) } \\
\text { Graduate }\end{array}$ \\
\hline \multicolumn{7}{|l|}{ GPA Threshold } \\
\hline Public Four-Year Only & 6559 & $\begin{array}{l}-0.036 * \\
(0.022)\end{array}$ & $\begin{array}{r}0.031 \\
(0.023)\end{array}$ & $\begin{array}{r}0.009 \\
(0.007)\end{array}$ & $\begin{array}{l}0.077^{* * *} \\
(0.024)\end{array}$ & $\begin{array}{l}0.040^{* *} \\
(0.018)\end{array}$ \\
\hline Control Mean & & $13.5 \%$ & $58.3 \%$ & $2.4 \%$ & $55.2 \%$ & $17.2 \%$ \\
\hline Any Private & 5165 & $\begin{array}{r}0.005 \\
(0.025)\end{array}$ & $\begin{array}{r}0.015 \\
(0.024)\end{array}$ & $\begin{array}{r}0.023 \\
(0.026)\end{array}$ & $\begin{array}{r}0.003 \\
(0.028)\end{array}$ & $\begin{array}{c}0.035^{*} \\
(0.021)\end{array}$ \\
\hline Control Mean & & $15.8 \%$ & $30.7 \%$ & $24.5 \%$ & $53.6 \%$ & $17.7 \%$ \\
\hline Community College, No Private & 7278 & $\begin{array}{r}0.010 \\
(0.023)\end{array}$ & $\begin{array}{r}0.004 \\
(0.019)\end{array}$ & $\begin{array}{r}-0.002 \\
(0.007)\end{array}$ & $\begin{array}{l}0.054^{* *} \\
(0.023)\end{array}$ & $\begin{array}{r}0.021 \\
(0.013)\end{array}$ \\
\hline Control Mean & & $44.6 \%$ & $23.3 \%$ & $1.4 \%$ & $36.2 \%$ & $9.0 \%$ \\
\hline \multicolumn{7}{|l|}{ Income Threshold } \\
\hline Public Four-Year Only & 3580 & $\begin{array}{r}-0.003 \\
(0.026)\end{array}$ & $\begin{array}{r}0.043 \\
(0.029)\end{array}$ & $\begin{array}{r}-0.003 \\
(0.009)\end{array}$ & $\begin{array}{r}0.018 \\
(0.030)\end{array}$ & $\begin{array}{r}0.007 \\
(0.028)\end{array}$ \\
\hline Control Mean & & $10.6 \%$ & $64.4 \%$ & $2.2 \%$ & $64.7 \%$ & $23.3 \%$ \\
\hline Any Private & 3556 & $\begin{array}{l}-0.044^{*} \\
(0.027)\end{array}$ & $\begin{array}{l}-0.102^{* * *} \\
(0.030)\end{array}$ & $\begin{array}{l}0.109 * * * \\
(0.033)\end{array}$ & $\begin{array}{r}0.046 \\
(0.030)\end{array}$ & $\begin{array}{r}0.002 \\
(0.030)\end{array}$ \\
\hline Control Mean & & $9.8 \%$ & $35.3 \%$ & $31.0 \%$ & $65.5 \%$ & $28.1 \%$ \\
\hline Community College, No Private & 1769 & $\begin{array}{r}-0.024 \\
(0.047)\end{array}$ & $\begin{array}{r}0.017 \\
(0.044)\end{array}$ & $\begin{array}{r}-0.012 \\
(0.014)\end{array}$ & $\begin{array}{r}0.007 \\
(0.048)\end{array}$ & $\begin{array}{l}0.102^{* * *} \\
(0.031)\end{array}$ \\
\hline Control Mean & & $34.9 \%$ & $36.0 \%$ & $2.1 \%$ & $51.9 \%$ & $14.8 \%$ \\
\hline
\end{tabular}

Notes: ${ }^{*} \mathrm{p}<0.1,{ }^{* *} \mathrm{p}<0.05,{ }^{* * *} \mathrm{p}<0.01$. All regressions include year-by-family size fixed effects. GPA regressions include students within 0.3 of the GPA threshold, and income regressions include students within $\$ 10,000$ of the income threshold. Standard errors are heteroskedasticity-robust in all regressions. Reduced form control value means are all students within 0.05 GPA (for GPA thresholds) or within \$1000 (for income thresholds). NSC regressions only include individuals who list NSC covered schools on their FAFSA. 
Appendix Table A11: Heterogeneity in Effects by Income and GPA

\begin{tabular}{|c|c|c|c|c|c|c|c|}
\hline & Attend & $\begin{array}{c}\text { CA } \\
\text { Community }\end{array}$ & $\begin{array}{c}\text { CA Four-Year } \\
\text { Public } \\
\end{array}$ & CA Private & $\begin{array}{l}\text { Bachelor's } \\
\text { Degree }\end{array}$ & $\begin{array}{l}\text { Graduate } \\
\text { Degree }\end{array}$ & \\
\hline \multicolumn{8}{|l|}{ GPA Threshold } \\
\hline Middle-income & $\begin{array}{c}0.003 \\
(0.006)\end{array}$ & $\begin{array}{c}0.002 \\
(0.011)\end{array}$ & $\begin{array}{l}-0.006 \\
(0.015)\end{array}$ & $\begin{array}{c}0.007 \\
(0.008)\end{array}$ & $\begin{array}{l}0.048 * * \\
(0.023)\end{array}$ & $\begin{array}{c}0.026^{*} \\
(0.015)\end{array}$ & \\
\hline Low-income & $\begin{array}{c}0.007 \\
(0.008)\end{array}$ & $\begin{array}{l}-0.029 \\
(0.020)\end{array}$ & $\begin{array}{c}0.011 \\
(0.019)\end{array}$ & $\begin{array}{l}-0.003 \\
(0.014)\end{array}$ & $\begin{array}{l}0.041^{* *} \\
(0.017)\end{array}$ & $\begin{array}{l}0.035^{* *} \\
(0.014)\end{array}$ & \\
\hline \multicolumn{8}{|c|}{ Income Threshold } \\
\hline GPA $>=3.5$ & $\begin{array}{c}0.001 \\
(0.004)\end{array}$ & $\begin{array}{l}-0.023 \\
(0.016)\end{array}$ & $\begin{array}{c}-0.053^{* * *} \\
(0.018)\end{array}$ & $\begin{array}{c}0.068 * * * \\
(0.017)\end{array}$ & $\begin{array}{r}0.010 \\
(0.026)\end{array}$ & $\begin{array}{r}0.040 \\
(0.026)\end{array}$ & \\
\hline GPA $<3.5$ & $\begin{array}{l}-0.002 \\
(0.006)\end{array}$ & $\begin{array}{l}-0.032 \\
(0.022)\end{array}$ & $\begin{array}{l}-0.040 * \\
(0.021)\end{array}$ & $\begin{array}{c}0.039 * * \\
(0.018)\end{array}$ & $\begin{array}{l}0.049 * \\
(0.030)\end{array}$ & $\begin{array}{r}0.016 \\
(0.023)\end{array}$ & \\
\hline & $\begin{array}{l}\text { Filed a tax } \\
\text { return }\end{array}$ & $\begin{array}{l}\text { Log labor } \\
\text { income }\end{array}$ & $\begin{array}{c}\text { Income } \\
\text { percentile }\end{array}$ & $\begin{array}{c}\text { Log HH- } \\
\text { adjusted AGI }\end{array}$ & Live in CA & Married & Has kids \\
\hline \multicolumn{8}{|l|}{ GPA Threshold } \\
\hline Middle-income & $\begin{array}{l}0.010 * * \\
(0.005)\end{array}$ & $\begin{array}{c}0.059 * * \\
(0.024)\end{array}$ & $\begin{array}{l}1.442 * * \\
(0.594)\end{array}$ & $\begin{array}{c}0.035^{* *} \\
(0.017)\end{array}$ & $\begin{array}{l}-0.010 \\
(0.009)\end{array}$ & $\begin{array}{c}0.012 \\
(0.012)\end{array}$ & $\begin{array}{l}-0.007 \\
(0.009)\end{array}$ \\
\hline Low-income & $\begin{array}{l}-0.003 \\
(0.010)\end{array}$ & $\begin{array}{l}0.050 * \\
(0.027)\end{array}$ & $\begin{array}{c}1.196 \\
(0.793)\end{array}$ & $\begin{array}{c}0.027 \\
(0.026)\end{array}$ & $\begin{array}{c}0.004 \\
(0.008)\end{array}$ & $\begin{array}{c}-0.048 * * \\
(0.018)\end{array}$ & $\begin{array}{c}-0.044 * * * \\
(0.016)\end{array}$ \\
\hline \multicolumn{8}{|c|}{ Income Threshold } \\
\hline GPA $>=3.5$ & $\begin{array}{c}-0.009 * * * \\
(0.004)\end{array}$ & $\begin{array}{l}-0.016 \\
(0.020)\end{array}$ & $\begin{array}{l}-0.726 \\
(0.487)\end{array}$ & $\begin{array}{c}0.003 \\
(0.016)\end{array}$ & $\begin{array}{l}0.013^{*} \\
(0.007)\end{array}$ & $\begin{array}{c}0.009 \\
(0.009)\end{array}$ & $\begin{array}{c}0.003 \\
(0.008)\end{array}$ \\
\hline GPA $<3.5$ & $\begin{array}{l}-0.000 \\
(0.005)\end{array}$ & $\begin{array}{l}-0.026 \\
(0.024)\end{array}$ & $\begin{array}{l}-0.207 \\
(0.555)\end{array}$ & $\begin{array}{l}-0.017 \\
(0.018)\end{array}$ & $\begin{array}{c}0.040 * * * \\
(0.008)\end{array}$ & $\begin{array}{l}-0.001 \\
(0.010)\end{array}$ & $\begin{array}{c}0.004 \\
(0.010)\end{array}$ \\
\hline
\end{tabular}

Notes: ${ }^{*} p<0.1,{ }^{* *} p<0.05,{ }^{* * *} p<0.01$. All regressions include year-by-family size fixed effects, cohort fixed effects and tax year fixed effects. GPA regressions include students within 0.3 of the GPA threshold, and income regressions include students within $\$ 10,000$ of the income threshold. Standard errors are clustered by GPA for GPA threshold regressions and are heteroskedasticity-robust in income threshold regressions. Reduced form control value means are all students within 0.05 GPA (for GPA thresholds) or within $\$ 1000$ (for income thresholds). 
Appendix Table A12: Heterogeneity in Attendance Results by Gender and Application Year

\begin{tabular}{|c|c|c|c|c|c|c|}
\hline & Attend & $\begin{array}{c}\text { CA Community } \\
\text { College }\end{array}$ & $\begin{array}{l}\text { CA Four-Year } \\
\text { Public } \\
\end{array}$ & CA Private & $\begin{array}{l}\text { Bachelor's } \\
\text { Degree }\end{array}$ & $\begin{array}{l}\text { Graduate } \\
\text { Degree }\end{array}$ \\
\hline GPA Threshold & & & & & & \\
\hline Female & $\begin{array}{l}-0.002 \\
(0.006)\end{array}$ & $\begin{array}{l}-0.010 \\
(0.014)\end{array}$ & $\begin{array}{l}-0.012 \\
(0.016)\end{array}$ & $\begin{array}{l}-0.000 \\
(0.008)\end{array}$ & $\begin{array}{l}0.068 * * * \\
(0.019)\end{array}$ & $\begin{array}{l}0.046^{* * * *} \\
(0.012)\end{array}$ \\
\hline Male & $\begin{array}{l}0.014 * * \\
(0.007)\end{array}$ & $\begin{array}{l}-0.014 \\
(0.020)\end{array}$ & $\begin{array}{c}0.019 \\
(0.015)\end{array}$ & $\begin{array}{c}0.006 \\
(0.010)\end{array}$ & $\begin{array}{r}0.017 \\
(0.023)\end{array}$ & $\begin{array}{r}0.009 \\
(0.020)\end{array}$ \\
\hline Application Year $=1998$ & $\begin{array}{c}0.008 \\
(0.009)\end{array}$ & $\begin{array}{c}-0.038 * * \\
(0.017)\end{array}$ & $\begin{array}{c}0.016 \\
(0.018)\end{array}$ & $\begin{array}{c}0.009 \\
(0.013)\end{array}$ & $\begin{array}{c}0.043^{*} \\
(0.022)\end{array}$ & $\begin{array}{r}0.014 \\
(0.020)\end{array}$ \\
\hline Application Year $=1999$ & $\begin{array}{c}0.007 \\
(0.007)\end{array}$ & $\begin{array}{l}-0.002 \\
(0.016)\end{array}$ & $\begin{array}{l}-0.010 \\
(0.020)\end{array}$ & $\begin{array}{l}-0.008 \\
(0.011)\end{array}$ & $\begin{array}{l}0.050 * * \\
(0.024)\end{array}$ & $\begin{array}{l}0.042 * * * \\
(0.013)\end{array}$ \\
\hline Application Year $=2000$ & $\begin{array}{l}-0.001 \\
(0.010)\end{array}$ & $\begin{array}{c}0.008 \\
(0.020)\end{array}$ & $\begin{array}{l}-0.005 \\
(0.024)\end{array}$ & $\begin{array}{c}0.011 \\
(0.015)\end{array}$ & $\begin{array}{r}0.043 \\
(0.033)\end{array}$ & $\begin{array}{l}0.042^{* *} \\
(0.017)\end{array}$ \\
\hline \multicolumn{7}{|l|}{ Income Threshold } \\
\hline Female & $\begin{array}{l}-0.004 \\
(0.004)\end{array}$ & $\begin{array}{l}-0.025 \\
(0.017)\end{array}$ & $\begin{array}{c}-0.049 * * * \\
(0.018)\end{array}$ & $\begin{array}{c}0.047 * * * \\
(0.016)\end{array}$ & $\begin{array}{r}0.025 \\
(0.025)\end{array}$ & $\begin{array}{r}0.001 \\
(0.023)\end{array}$ \\
\hline Male & $\begin{array}{c}0.003 \\
(0.006)\end{array}$ & $\begin{array}{l}-0.035^{*} \\
(0.020)\end{array}$ & $\begin{array}{c}-0.042^{* *} \\
(0.021)\end{array}$ & $\begin{array}{c}0.068 * * * \\
(0.018)\end{array}$ & $\begin{array}{r}0.039 \\
(0.035)\end{array}$ & $\begin{array}{l}0.067 * * \\
(0.028)\end{array}$ \\
\hline Application Year $=1998$ & $\begin{array}{l}-0.009 \\
(0.007)\end{array}$ & $\begin{array}{c}-0.073 * * * \\
(0.023)\end{array}$ & $\begin{array}{c}-0.050 * * \\
(0.025)\end{array}$ & $\begin{array}{c}0.048 * * \\
(0.022)\end{array}$ & $\begin{array}{r}0.029 \\
(0.033)\end{array}$ & $\begin{array}{r}0.029 \\
(0.031)\end{array}$ \\
\hline Application Year $=1999$ & $\begin{array}{c}0.002 \\
(0.005)\end{array}$ & $\begin{array}{c}0.011 \\
(0.022)\end{array}$ & $\begin{array}{c}-0.056^{* *} \\
(0.024)\end{array}$ & $\begin{array}{c}0.065^{* * *} \\
(0.021)\end{array}$ & $\begin{array}{r}0.052 \\
(0.034)\end{array}$ & $\begin{array}{r}0.026 \\
(0.031)\end{array}$ \\
\hline Application Year $=2000$ & $\begin{array}{c}0.003 \\
(0.006)\end{array}$ & $\begin{array}{c}-0.028 \\
(0.023)\end{array}$ & $\begin{array}{c}-0.034 \\
(0.024)\end{array}$ & $\begin{array}{c}0.055^{* * *} \\
(0.021)\end{array}$ & $\begin{array}{r}0.009 \\
(0.034)\end{array}$ & $\begin{array}{r}0.033 \\
(0.029)\end{array}$ \\
\hline
\end{tabular}

Notes: This table presents estimates of the effect of Cal Grant eligibility on college enrollment and degree attainment outcomes, by gender and year of initial application. Regressions at the GPA threshold include applicants within 0.3 points of the GPA threshold, and regressions at the income threshold include applicants within $\$ 10,000$ of the income threshold. All regressions include student age, parental education, parental marital status, citizen status, and year-by-family size fixed effects. A linear function of the running variable and a uniform kernel are used. Standard errors are clustered by GPA for GPA threshold regressions and are heteroskedasticity-robust in income threshold regressions.

${ }^{*} \mathrm{p}<0.1,{ }^{* *} \mathrm{p}<0.05,{ }^{* * *} \mathrm{p}<0.01$. 
Appendix Table A13: Heterogeneity in Income and Demographic Results by Gender and Application Year

\begin{tabular}{|c|c|c|c|c|c|c|c|}
\hline & $\begin{array}{c}\text { Filed a tax } \\
\text { return }\end{array}$ & $\begin{array}{c}\text { Log labor } \\
\text { income }\end{array}$ & $\begin{array}{c}\text { Income } \\
\text { percentile }\end{array}$ & $\begin{array}{c}\text { Log HH- } \\
\text { adjusted AGI }\end{array}$ & Live in CA & Married & Has kids \\
\hline \multicolumn{8}{|l|}{ GPA Threshold } \\
\hline Female & $\begin{array}{c}0.004 \\
(0.007)\end{array}$ & $\begin{array}{l}0.045^{*} \\
(0.023)\end{array}$ & $\begin{array}{l}1.163^{*} \\
(0.650)\end{array}$ & $\begin{array}{c}0.024 \\
(0.022)\end{array}$ & $\begin{array}{l}-0.021 * \\
(0.011)\end{array}$ & $\begin{array}{l}-0.014 \\
(0.015)\end{array}$ & $\begin{array}{l}-0.024 * \\
(0.014)\end{array}$ \\
\hline Male & $\begin{array}{c}0.007 \\
(0.008)\end{array}$ & $\begin{array}{c}0.058 * * \\
(0.028)\end{array}$ & $\begin{array}{l}1.286 * \\
(0.675)\end{array}$ & $\begin{array}{l}0.038 * \\
(0.022)\end{array}$ & $\begin{array}{l}0.019 * \\
(0.010)\end{array}$ & $\begin{array}{l}-0.013 \\
(0.019)\end{array}$ & $\begin{array}{l}-0.014 \\
(0.015)\end{array}$ \\
\hline Application Year $=1998$ & $\begin{array}{c}0.019 * * \\
(0.009)\end{array}$ & $\begin{array}{c}0.088 * * * \\
(0.030)\end{array}$ & $\begin{array}{c}2.303^{* * *} \\
(0.731)\end{array}$ & $\begin{array}{c}0.070 * * * \\
(0.022)\end{array}$ & $\begin{array}{l}-0.010 \\
(0.011)\end{array}$ & $\begin{array}{l}-0.016 \\
(0.021)\end{array}$ & $\begin{array}{l}-0.014 \\
(0.017)\end{array}$ \\
\hline Application Year = 1999 & $\begin{array}{c}0.006 \\
(0.007)\end{array}$ & $\begin{array}{c}0.059 * * \\
(0.024)\end{array}$ & $\begin{array}{c}1.937 * * * \\
(0.658)\end{array}$ & $\begin{array}{c}0.025 \\
(0.021)\end{array}$ & $\begin{array}{l}-0.003 \\
(0.011)\end{array}$ & $\begin{array}{l}-0.018 \\
(0.012)\end{array}$ & $\begin{array}{l}-0.021 \\
(0.015)\end{array}$ \\
\hline Application Year $=2000$ & $\begin{array}{l}-0.013 \\
(0.010)\end{array}$ & $\begin{array}{c}0.007 \\
(0.032)\end{array}$ & $\begin{array}{l}-0.614 \\
(0.916)\end{array}$ & $\begin{array}{l}-0.008 \\
(0.038)\end{array}$ & $\begin{array}{c}0.001 \\
(0.013)\end{array}$ & $\begin{array}{l}-0.009 \\
(0.020)\end{array}$ & $\begin{array}{c}-0.039 * * * \\
(0.014)\end{array}$ \\
\hline \multicolumn{8}{|l|}{ Income Threshold } \\
\hline Female & $\begin{array}{l}-0.000 \\
(0.003)\end{array}$ & $\begin{array}{c}-0.014 \\
(0.021)\end{array}$ & $\begin{array}{l}-0.887 * \\
(0.474)\end{array}$ & $\begin{array}{c}-0.031 * * \\
(0.015)\end{array}$ & $\begin{array}{c}0.020^{* * *} \\
(0.007)\end{array}$ & $\begin{array}{c}-0.019 * * \\
(0.009)\end{array}$ & $\begin{array}{l}-0.012 \\
(0.008)\end{array}$ \\
\hline Male & $\begin{array}{c}-0.013^{* *} \\
(0.005)\end{array}$ & $\begin{array}{l}-0.030 \\
(0.023)\end{array}$ & $\begin{array}{c}0.078 \\
(0.570)\end{array}$ & $\begin{array}{l}0.036 * \\
(0.019)\end{array}$ & $\begin{array}{c}0.028 * * * \\
(0.008)\end{array}$ & $\begin{array}{c}0.041^{* * *} \\
(0.010)\end{array}$ & $\begin{array}{c}0.024 * * * \\
(0.009)\end{array}$ \\
\hline Application Year $=1998$ & $\begin{array}{c}-0.010^{* *} \\
(0.005)\end{array}$ & $\begin{array}{l}-0.033 \\
(0.026)\end{array}$ & $\begin{array}{l}-0.537 \\
(0.614)\end{array}$ & $\begin{array}{c}0.012 \\
(0.021)\end{array}$ & $\begin{array}{c}0.031^{* * *} \\
(0.010)\end{array}$ & $\begin{array}{c}0.018 \\
(0.012)\end{array}$ & $\begin{array}{c}0.014 \\
(0.011)\end{array}$ \\
\hline Application Year = 1999 & $\begin{array}{l}-0.003 \\
(0.005)\end{array}$ & $\begin{array}{c}-0.003 \\
(0.024)\end{array}$ & $\begin{array}{c}-0.032 \\
(0.592)\end{array}$ & $\begin{array}{c}-0.011 \\
(0.020)\end{array}$ & $\begin{array}{c}-0.000 \\
(0.009)\end{array}$ & $\begin{array}{c}0.007 \\
(0.012)\end{array}$ & $\begin{array}{c}0.012 \\
(0.011)\end{array}$ \\
\hline Application Year $=2000$ & $\begin{array}{c}-0.004 \\
(0.005)\end{array}$ & $\begin{array}{c}-0.024 \\
(0.029)\end{array}$ & $\begin{array}{c}-0.830 \\
(0.689)\end{array}$ & $\begin{array}{c}-0.012 \\
(0.021)\end{array}$ & $\begin{array}{c}0.040^{* * *} \\
(0.009)\end{array}$ & $\begin{array}{c}-0.007 \\
(0.011)\end{array}$ & $\begin{array}{c}-0.016 \\
(0.011)\end{array}$ \\
\hline
\end{tabular}

Notes: This table presents estimates of the effect of Cal Grant eligibility on income and demographic outcomes 10 to 14 years after application, by gender and year of initial application. Regressions at the GPA threshold include applicants within 0.3 points of the GPA threshold, and regressions at the income threshold include applicants within $\$ 10,000$ of the income threshold. All regressions include student age, parental education, parental marital status, citizen status, and year-by-family size fixed effects. A linear function of the running variable and a uniform kernel are used. Standard errors are clustered by GPA for GPA threshold regressions and are heteroskedasticity-robust in income threshold regressions.

$* \mathrm{p}<0.1, * * \mathrm{p}<0.05, * * * \mathrm{p}<0.01$. 

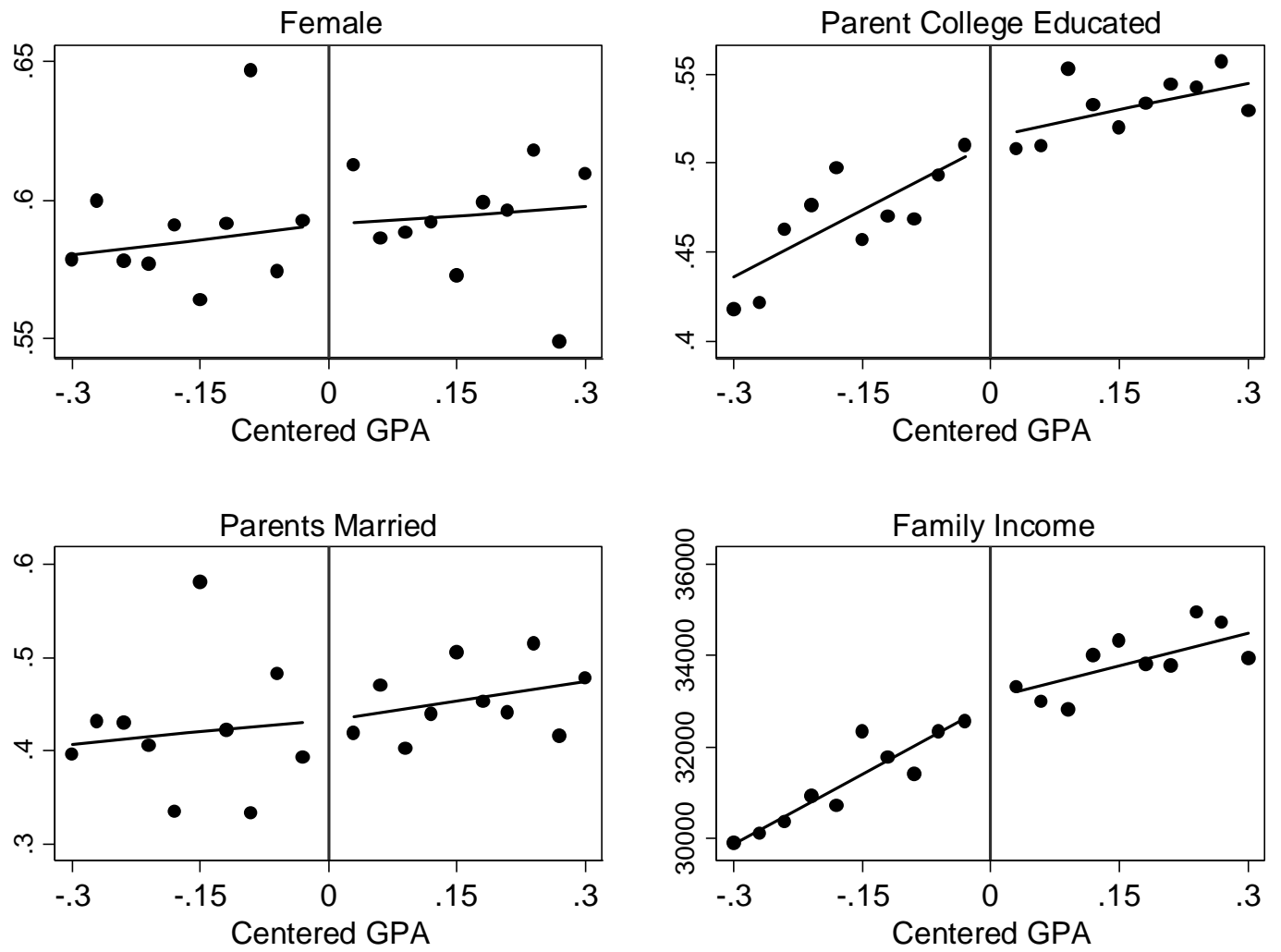

\section{Figure A1. Covariate BALANCE, GPA THRESHOLD}

Notes: This figure depicts demographic characteristics at the GPA threshold, pooled over cohorts. The figure includes students within 0.3 GPA points of the year-specific eligibility thresholds, binned by 0.03 GPA points relative to the threshold. 

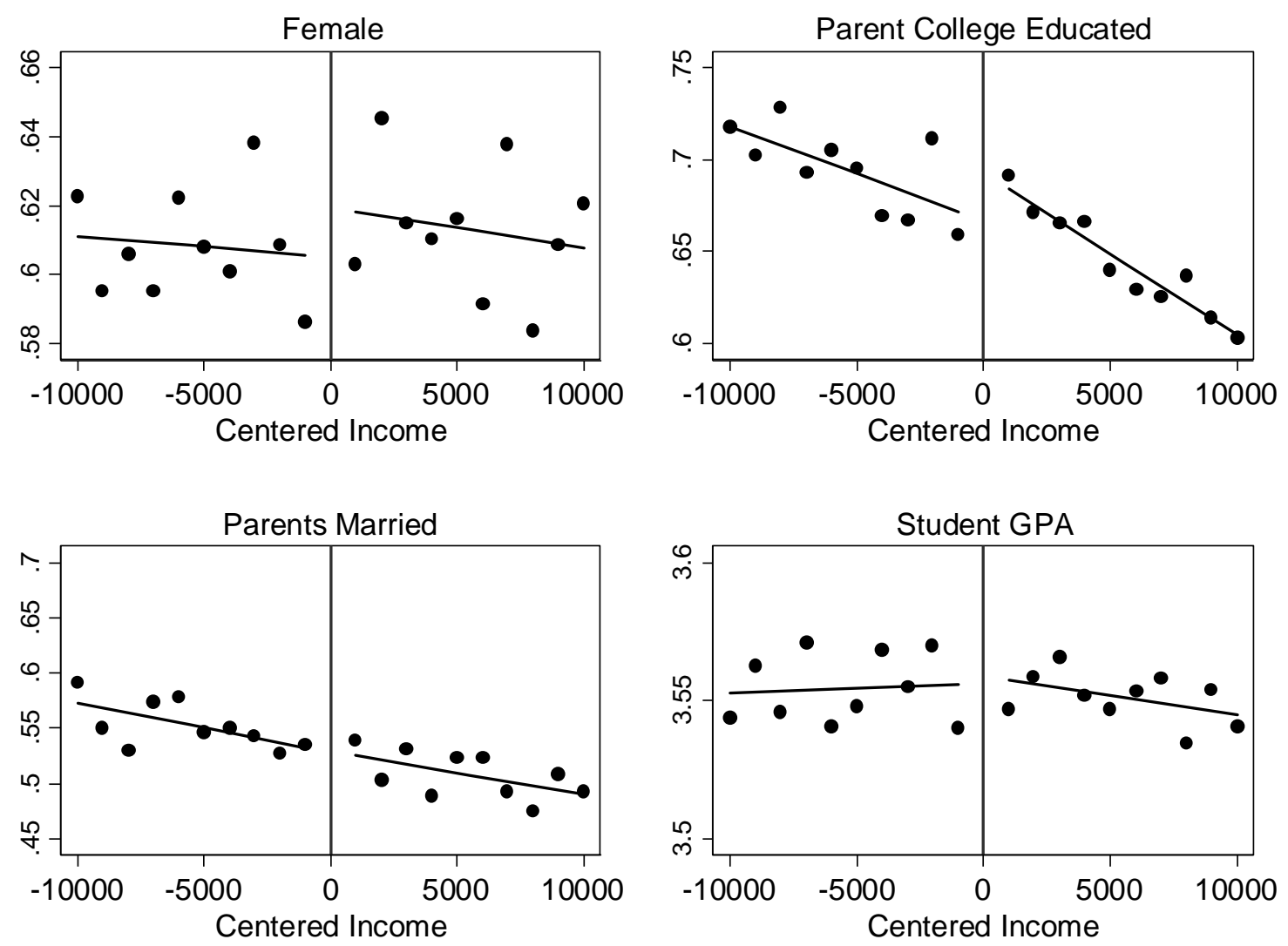

\section{Figure A2. COVARIATE BALANCE, INCOME THRESHOLD}

Notes: This figure depicts demographic characteristics at the income threshold, pooled over cohorts. The figure includes students within $\$ 10,000$ of the year-specific eligibility threshold, binned by $\$ 1,000$ relative to the threshold. Income is reversed so that values above the cutoff represent lower family incomes. 

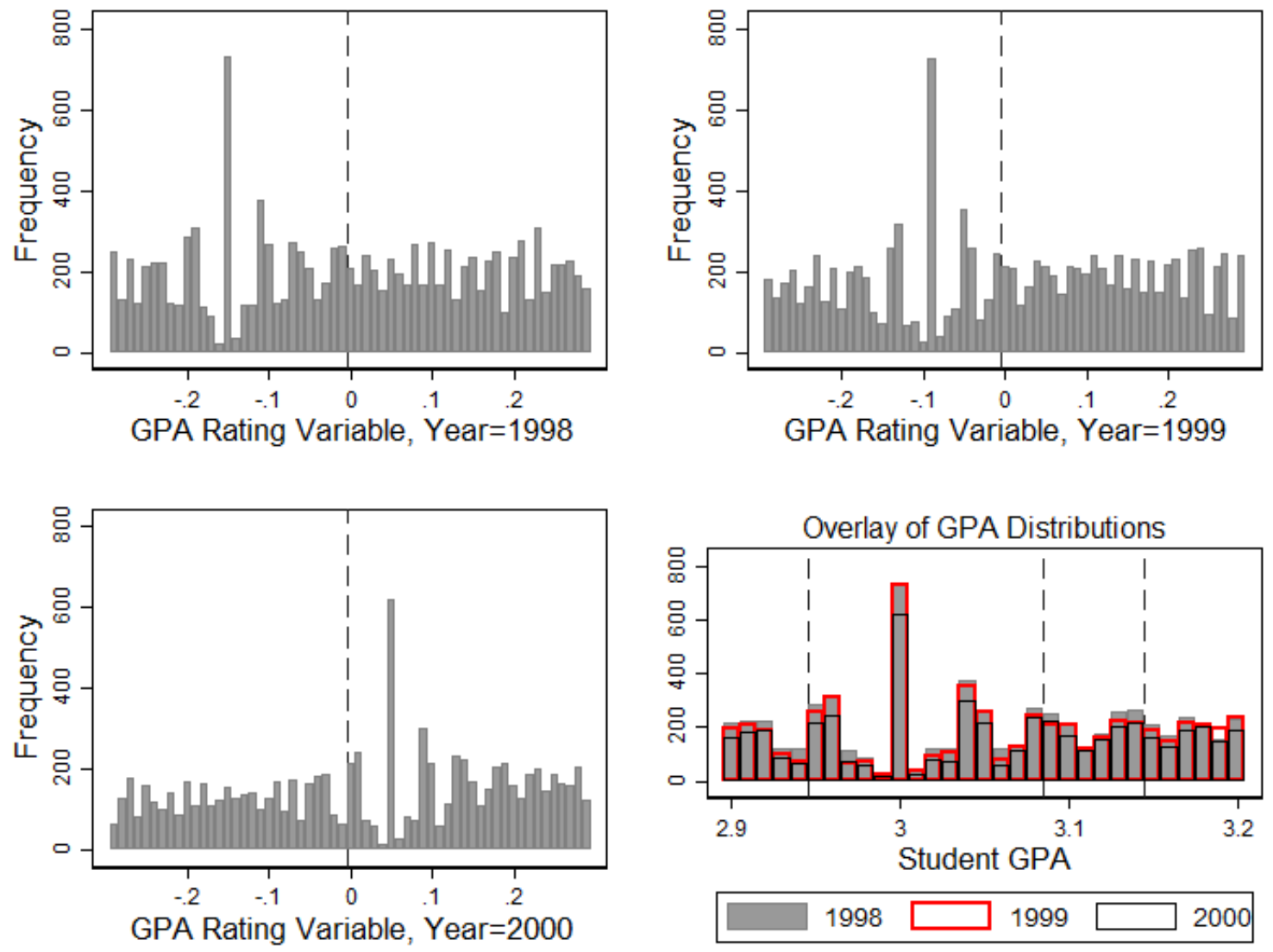

Figure A3. Histograms OF GPA Distribution

Notes: This figure depicts the distribution of students across the GPA distribution relative to the GPA threshold for each cohort separately, and then overlaid on top of one another in the bottom right panel. 


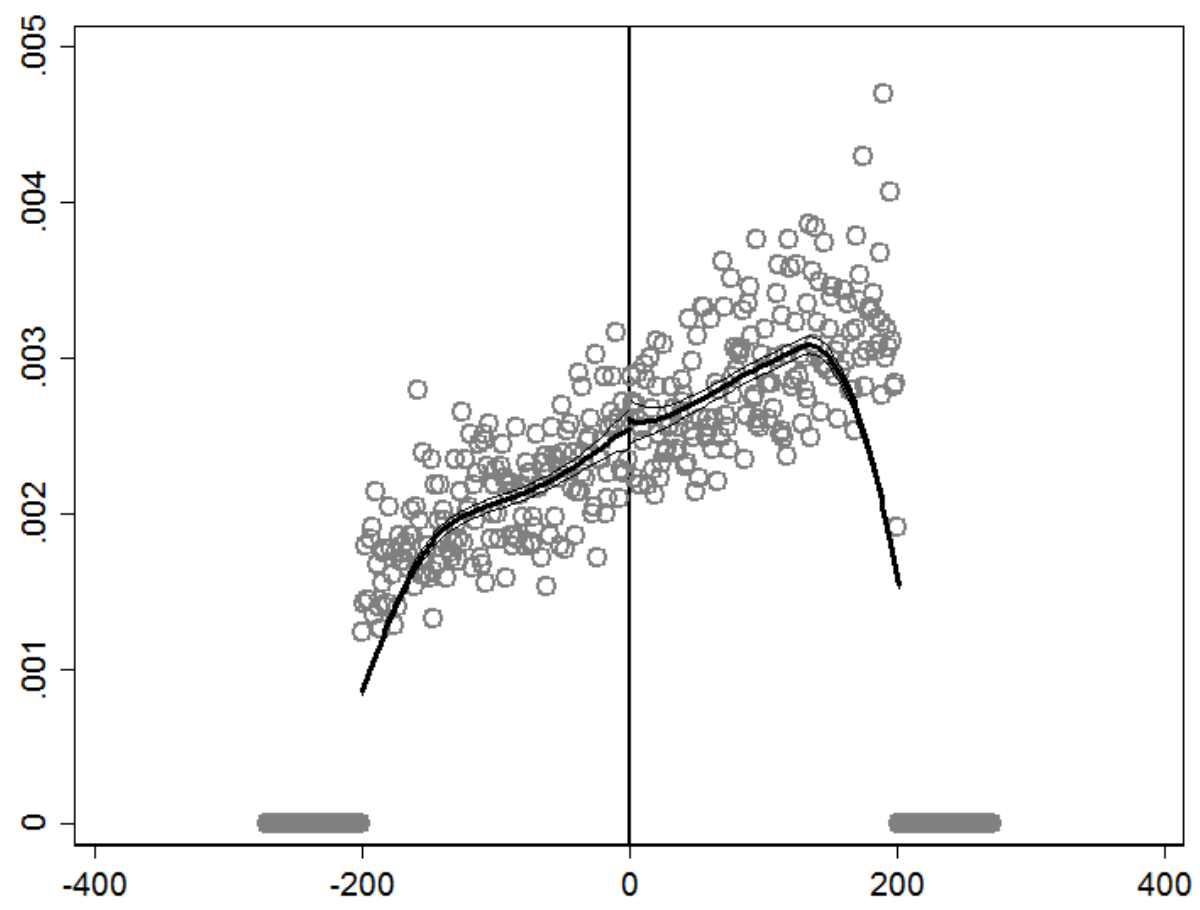

Figure A4. McCrary Test of Applicant Density at Income Threshold, Tax Data

Notes: This figure depictures the distribution of Cal Grant applicants on each side of the year-specific eligibility threshold, re-centered at zero. 


\section{NSC Degree Completion $(95 \% \mathrm{Cl})$}

\section{GPA Thresholds}
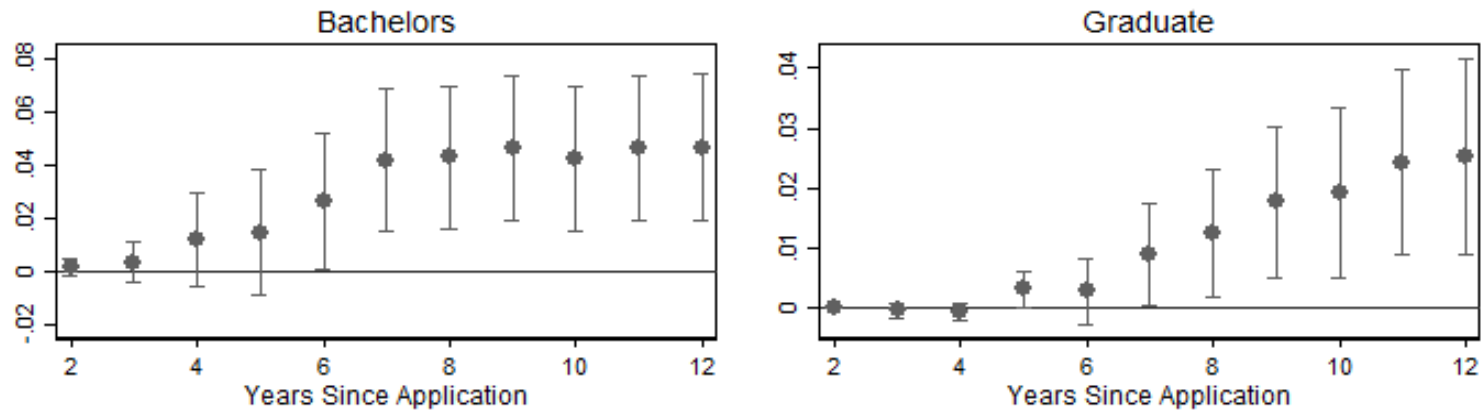

Income Threshold
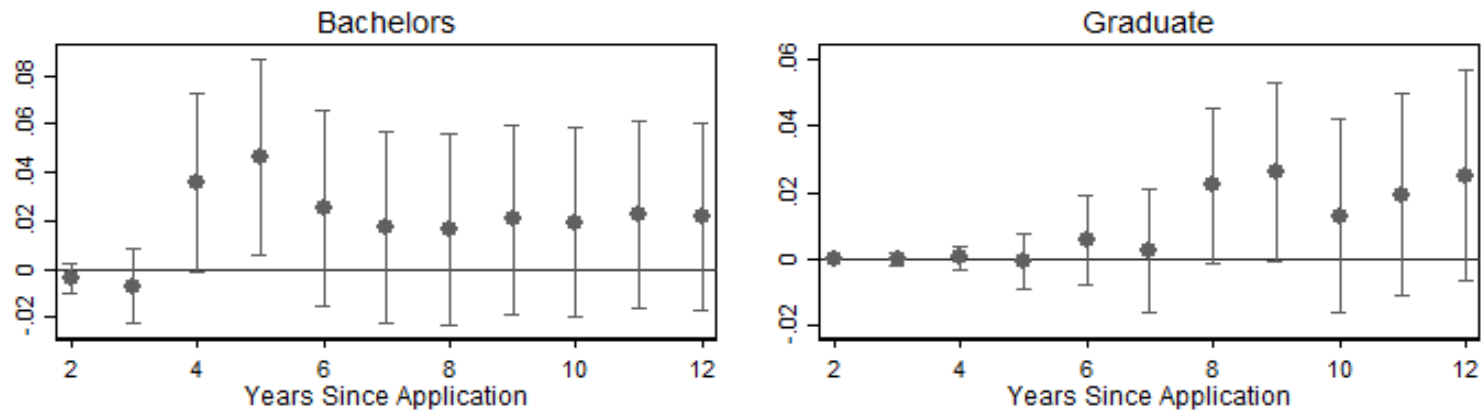

\section{Figure A5. Educational Attainment over Time}

Notes: This figure depicts the evolution of the effect of Cal Grant eligibility on degree completion since the year of application. The circles represent coefficients from our regression discontinuity specification for a specific year relative to time of application, and the dashed lines represent $95 \%$ confidence intervals. 

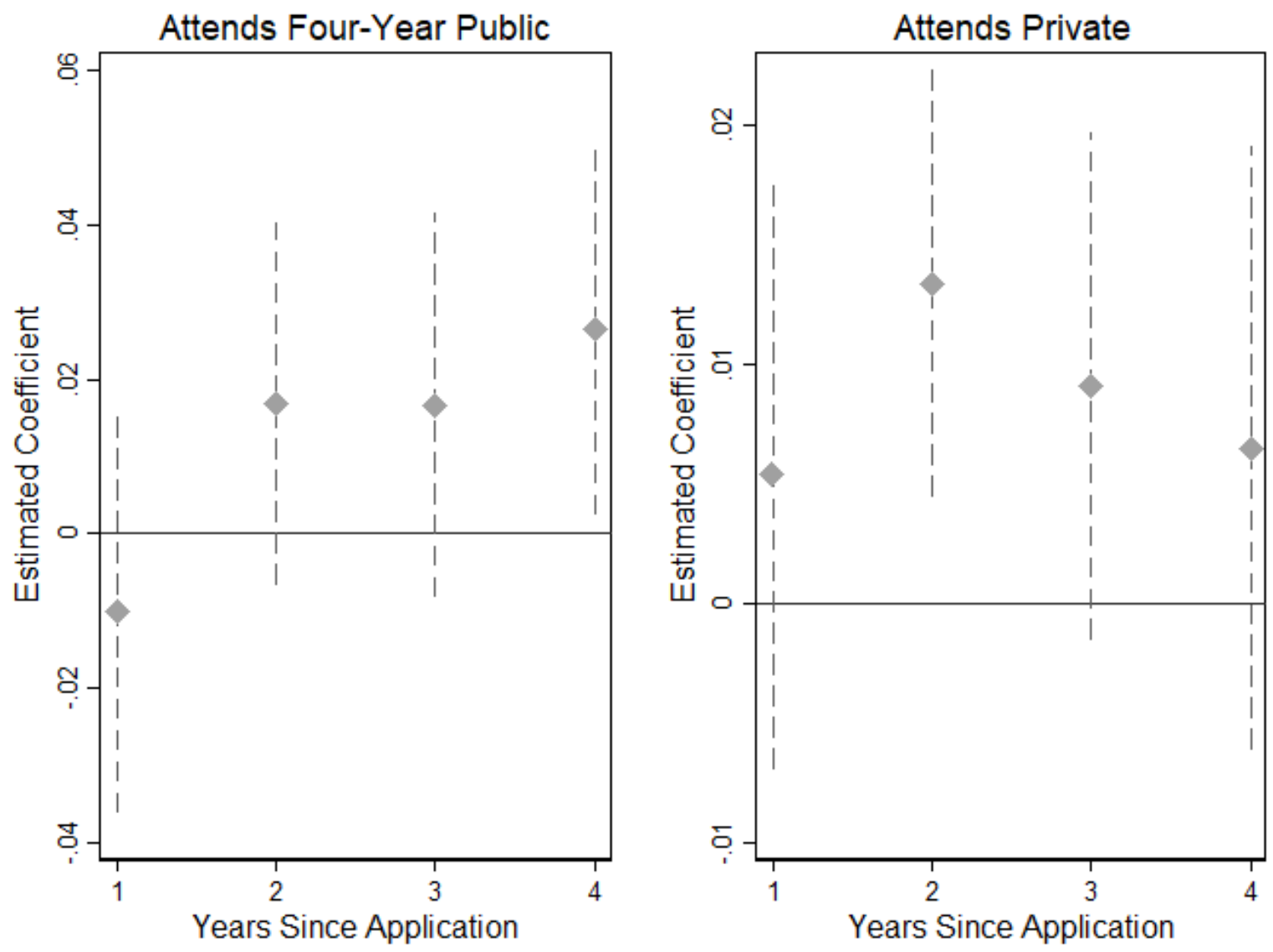

\section{Figure A6. Educational AtTendance OVER Time, GPA Threshold}

Notes: This figure depicts the evolution of the effect of Cal Grant eligibility on type of institution attended since the year of application at the GPA threshold. The diamonds represent coefficients from our regression discontinuity specification for a specific year relative to time of application, and the dashed lines represent $95 \%$ confidence intervals. 

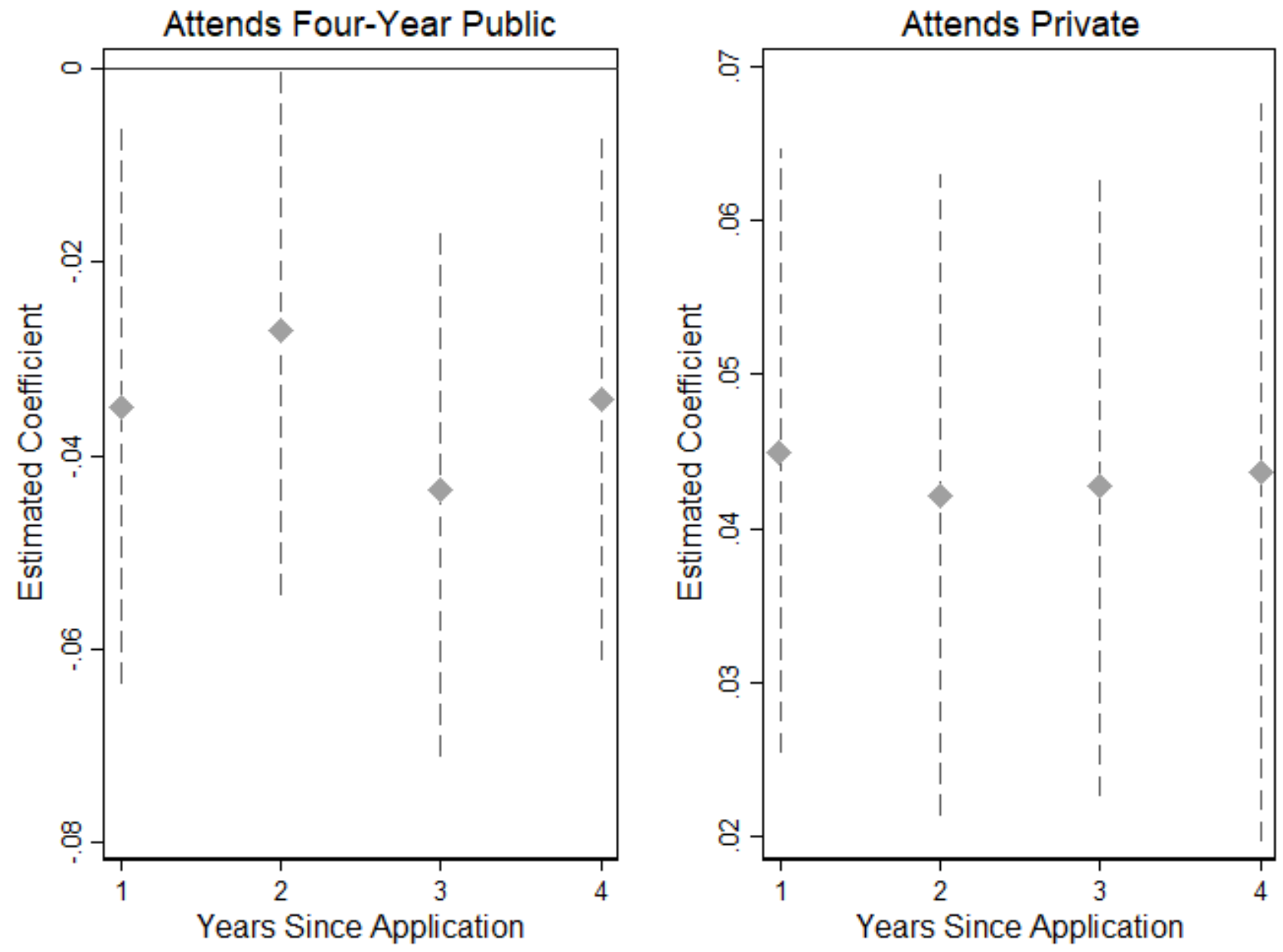

\section{Figure A7. Educational AtTENDANCE OVER Time, InCOME THRESHOLd}

Notes: This figure depicts the evolution of the effect of Cal Grant eligibility on type of institution attended since the year of application at the income threshold. The diamonds represent coefficients from our regression discontinuity specification for a specific year relative to time of application, and the dashed lines represent $95 \%$ confidence intervals. 

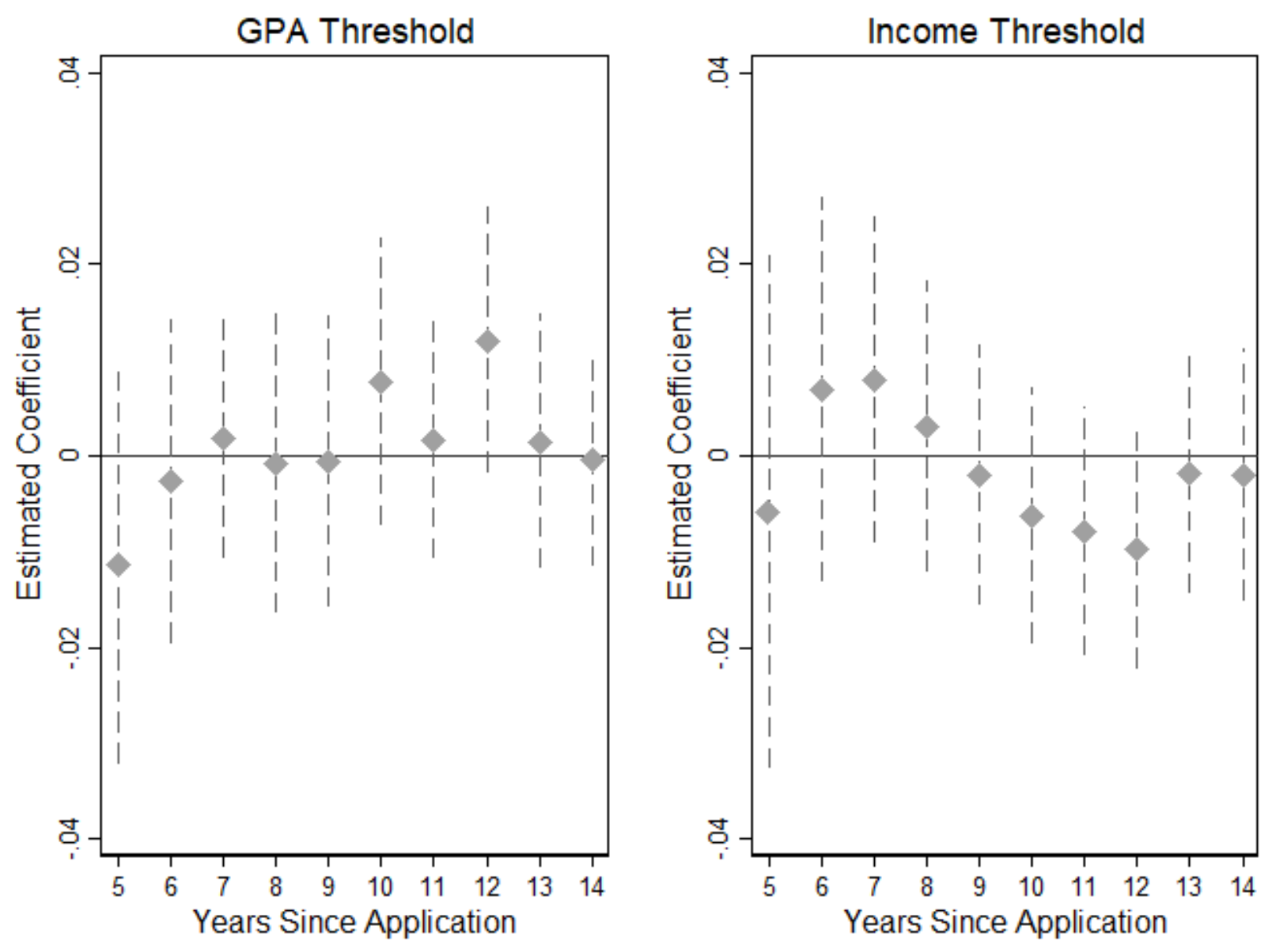

\section{Figure A8. TAX FiLing OVER Time}

Notes: This figure depicts the evolution of the effect of Cal Grant eligibility on the probability of filing a tax return since the year of application. The diamonds represent coefficients from our regression discontinuity specification for a specific year relative to time of application, and the dashed lines represent 95\% confidence intervals. The top panel includes students within 0.3 GPA points of the GPA threshold, and the bottom panel includes students within $\$ 10,000$ of the income threshold. The regressions include the student's age, a dummy for parental college attainment, a dummy for U.S. citizenship, a dummy for parents being married, and family size by year fixed effects. Standard errors for the left panel are clustered by the running variable, and standard errors in the right panel are heteroscedasticity robust. 


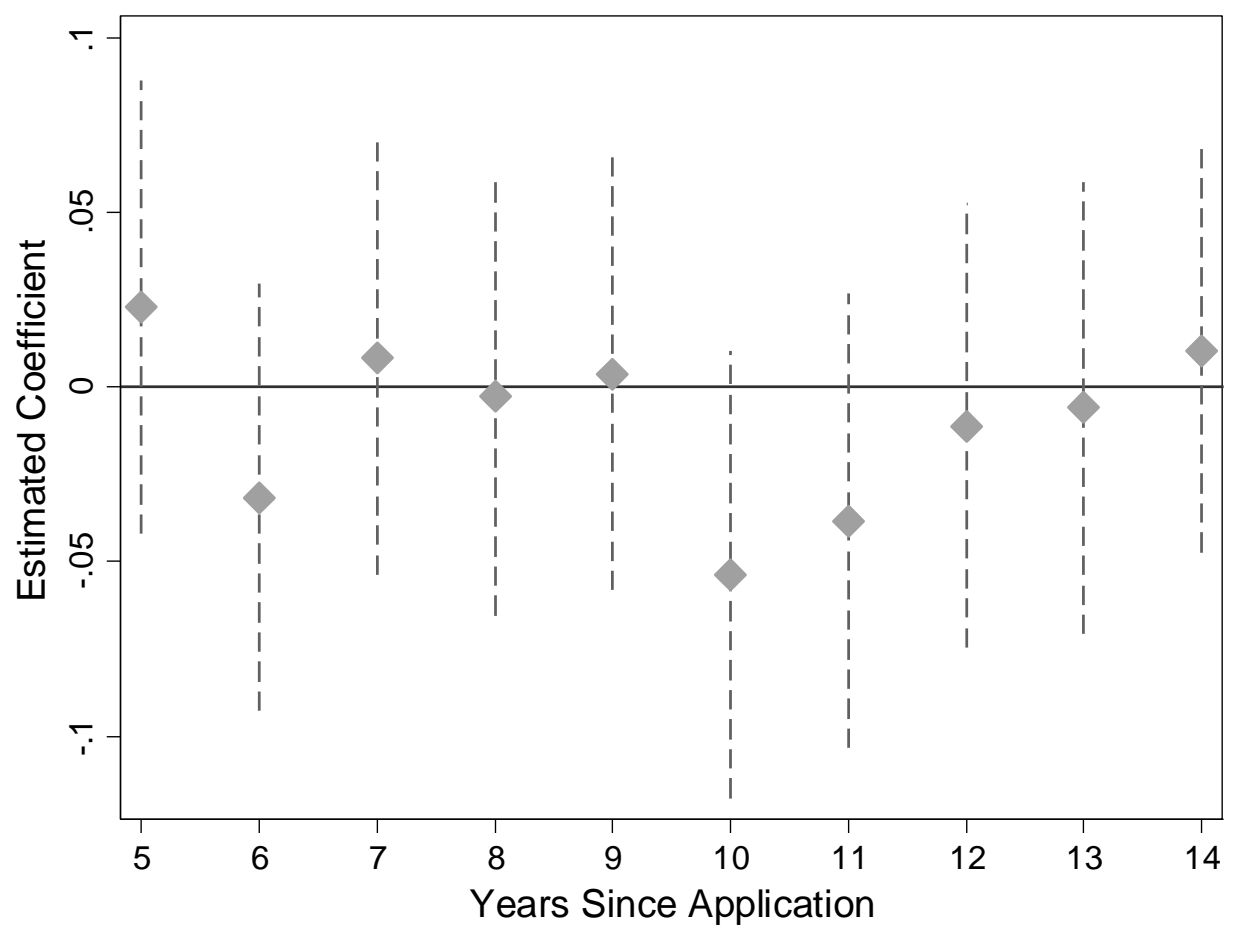

\section{FiguRE A9. LOg LABOR INCOME OVER TIME, INCOME THRESHOLD}

Notes: This figure depicts the evolution of the effect of Cal Grant eligibility on log labor income since the year of application. The diamonds represent coefficients from our regression discontinuity specification for a specific year relative to time of application, and the dashed lines represent $95 \%$ confidence intervals. The regressions include students within $\$ 10,000$ of the income threshold. The regressions include the student's age, a dummy for parental college attainment, a dummy for U.S. citizenship, a dummy for parents being married, and family size by year fixed effects. Standard errors are heteroscedasticity robust. 


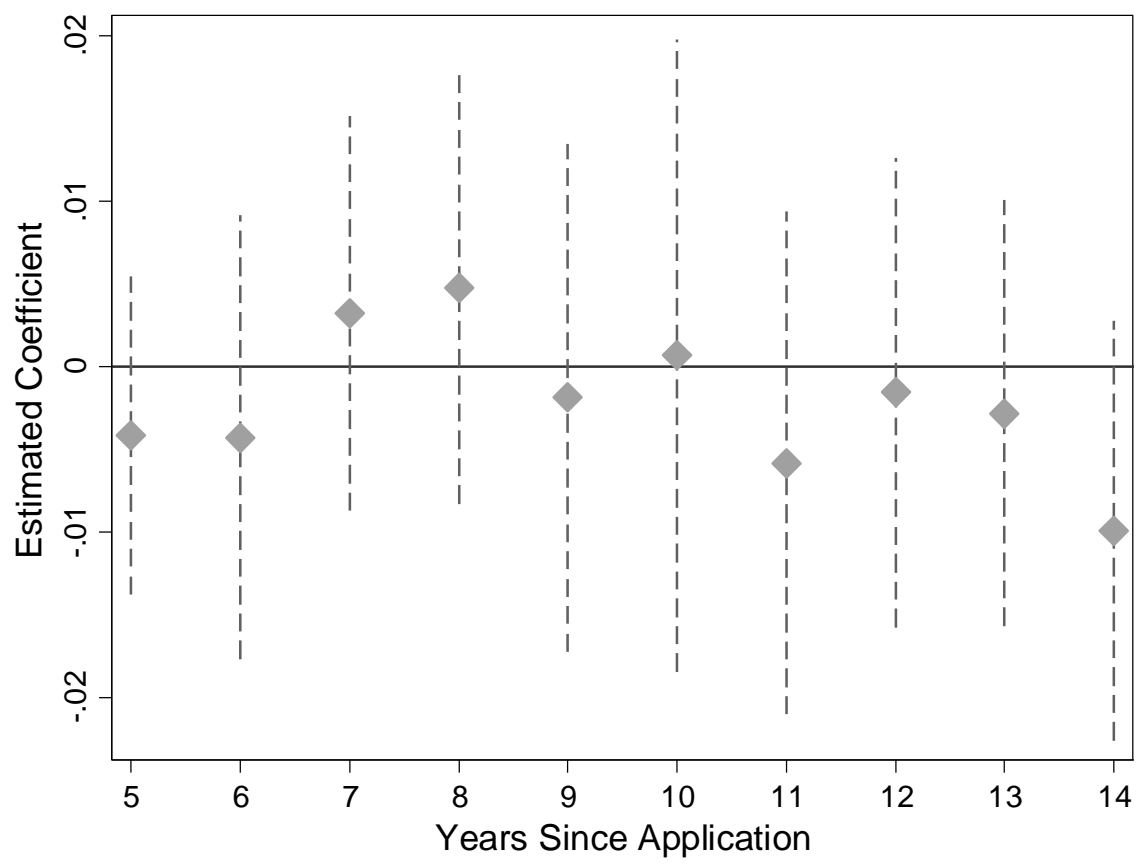

\section{FiguRE A10. RESIDENCy RESUlts OVER TIME, GPA THRESHOLD}

Notes: This figure depicts the evolution of the effect of Cal Grant eligibility on the probability of living in California (based on filing address). The diamonds represent coefficients from our regression discontinuity specification for a specific year relative to time of application, and the dashed lines represent 95\% confidence intervals. The regression includes students within 0.3 GPA points of the GPA threshold. The regressions include the student's age, a dummy for parental college attainment, a dummy for U.S. citizenship, a dummy for parents being married, and family size by year fixed effects. Standard errors are clustered by the running variable. 


\section{Appendix 3. RD Figures of All Outcome Variables}
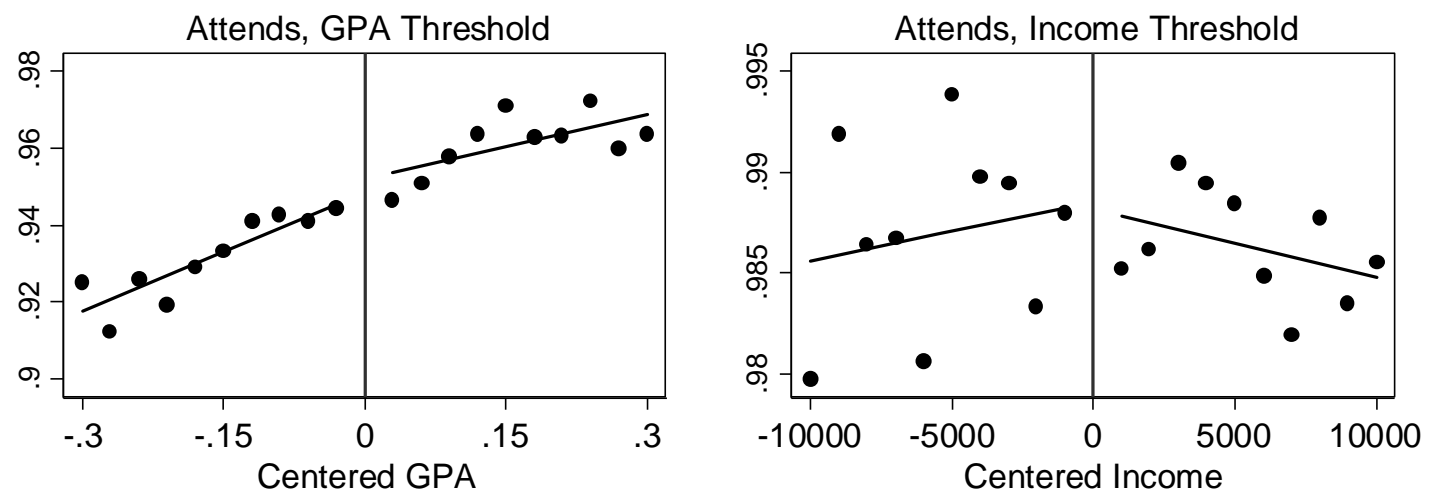

CA Community College, GPA Threshold

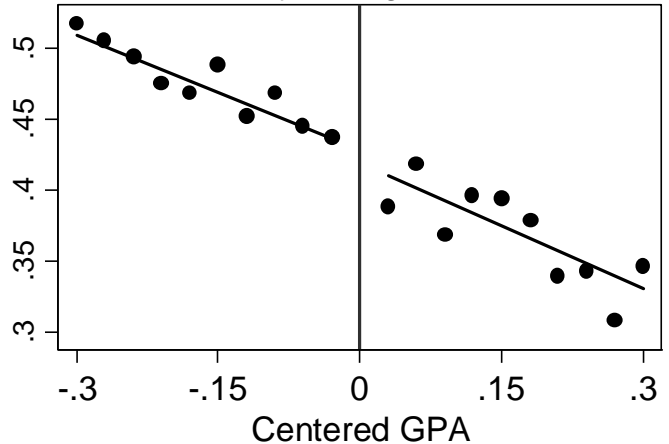

CA Community College, Income Threshold

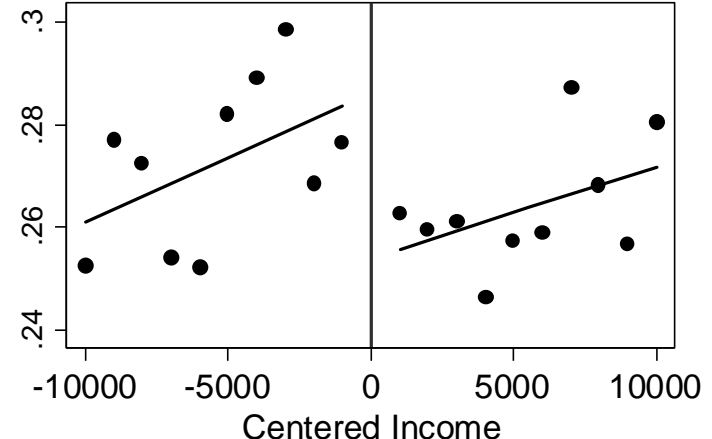

Notes: These figures plot the proportion of students who attend any college (top panel) or attend a community college in California (bottom panel) at any point between 1 and 4 years since their Cal Grant application, pooled over cohorts. Students are binned by 0.03 GPA points or $\$ 1,000$ relative to the year-specific eligibility threshold at the GPA and income thresholds, respectively. Income is reversed so that values above the cutoff represent lower family incomes; crossing the threshold from left to right indicates becoming eligible for the Cal Grant. 


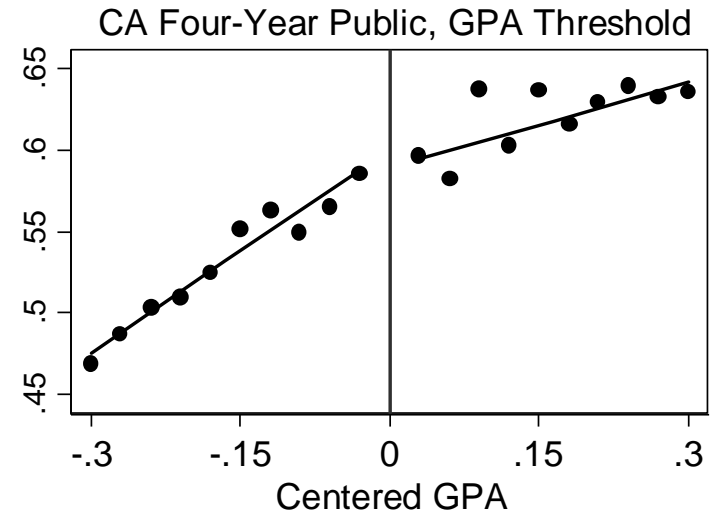

CA Four-Year Public, Income Threshold
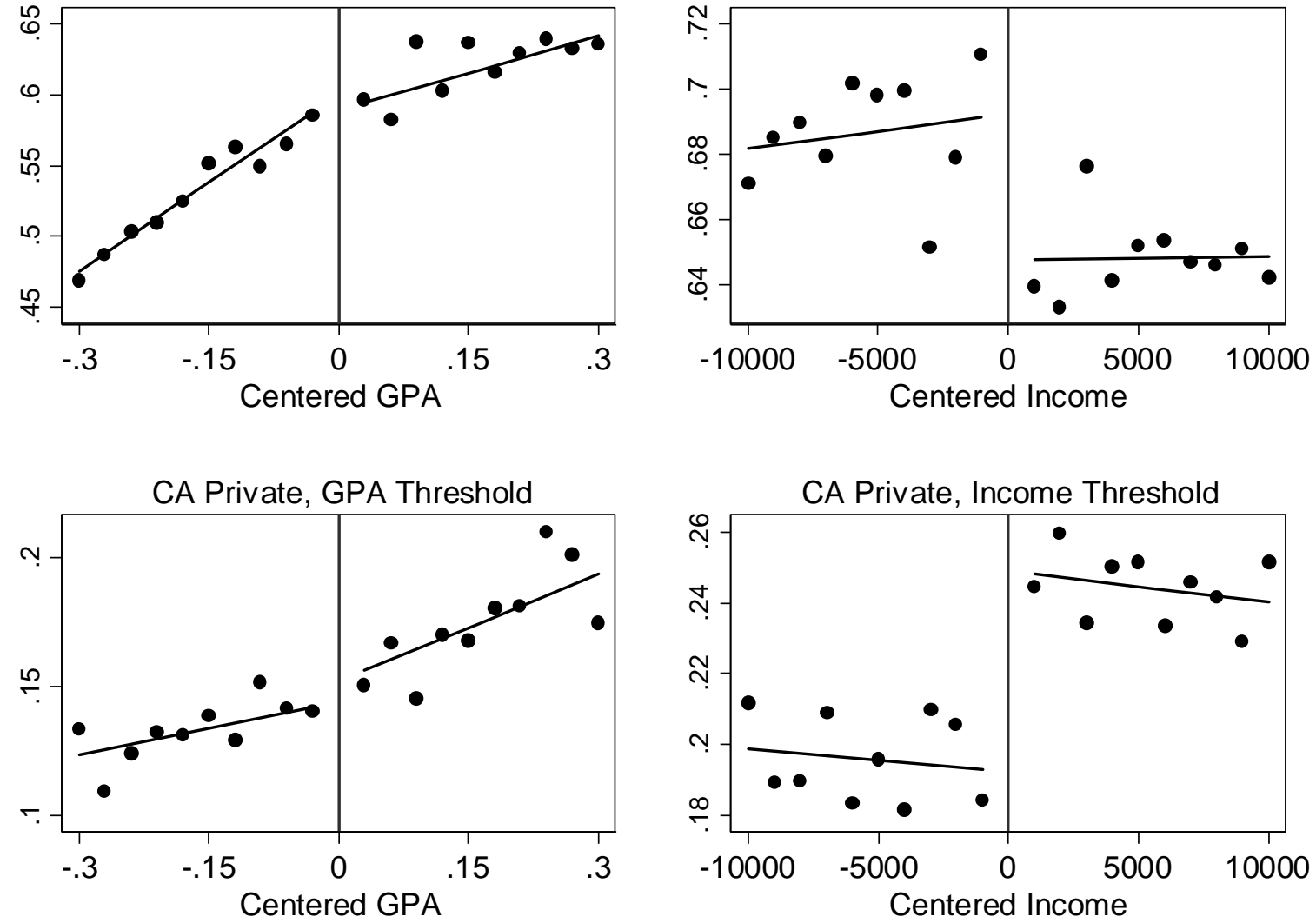

Notes: These figures plot the proportion of students who attend a four-year public institution (top panel) or a private institution (bottom panel) in California at any point between 1 and 4 years since their Cal Grant application, pooled over cohorts. Students are binned by 0.03 GPA points or $\$ 1,000$ relative to the year-specific eligibility threshold at the GPA and income thresholds, respectively. Income is reversed so that values above the cutoff represent lower family incomes; crossing the threshold from left to right indicates becoming eligible for the Cal Grant. 

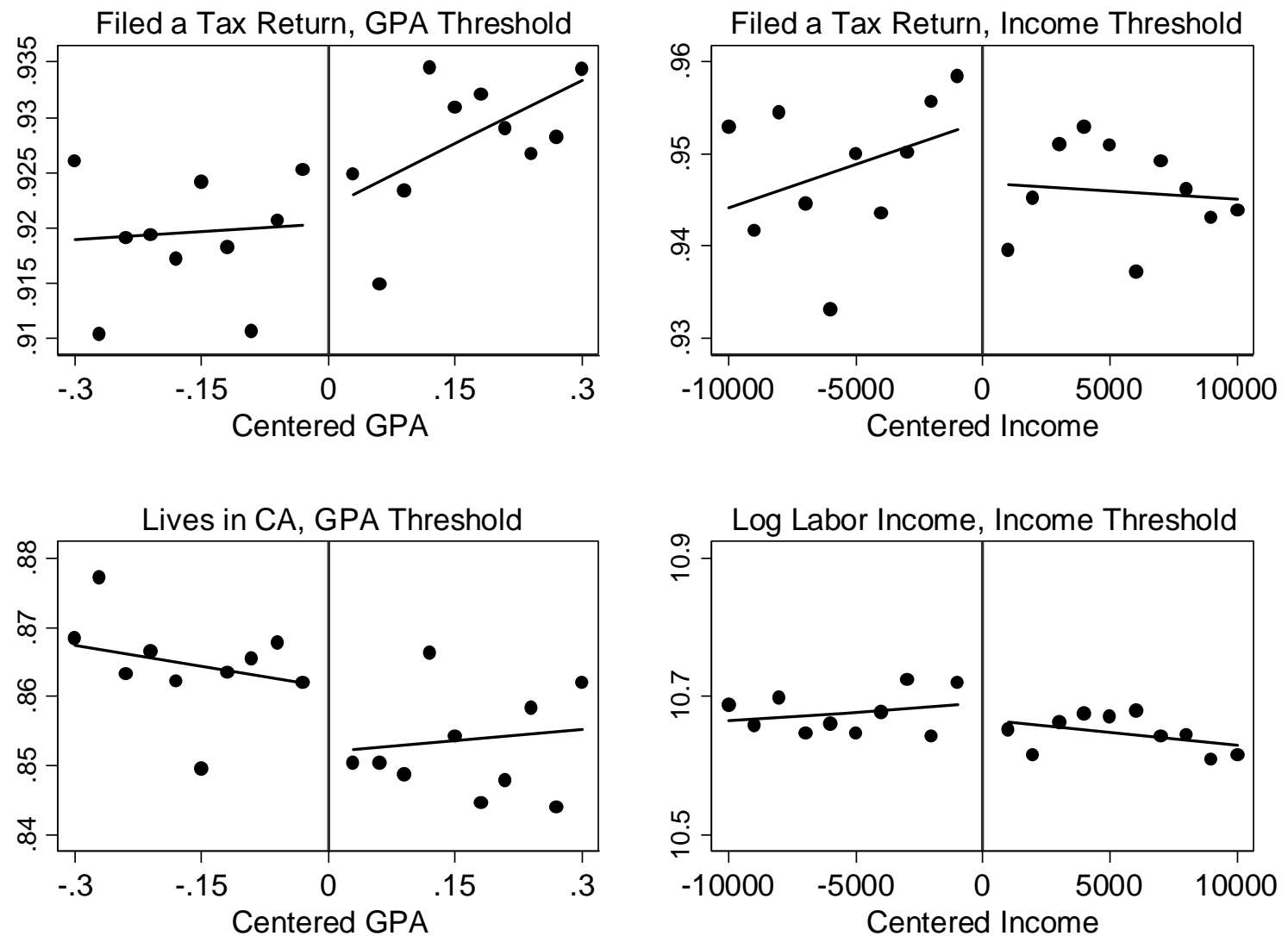

Notes: These figures plot the proportion of students who filed a tax return (top panel) at any point between 10 and 14 years since their Cal Grant application, pooled over cohorts. The bottom panel plots the proportion of students who ever lives in California based on their tax filing address at the GPA threshold (left), and the average log labor income at the income threshold (right) between 10 and 14 years since their Cal Grant application, pooled over cohorts. Income is reversed so that values above the cutoff represent lower family incomes; crossing the threshold from left to right indicates becoming eligible for the Cal Grant. 

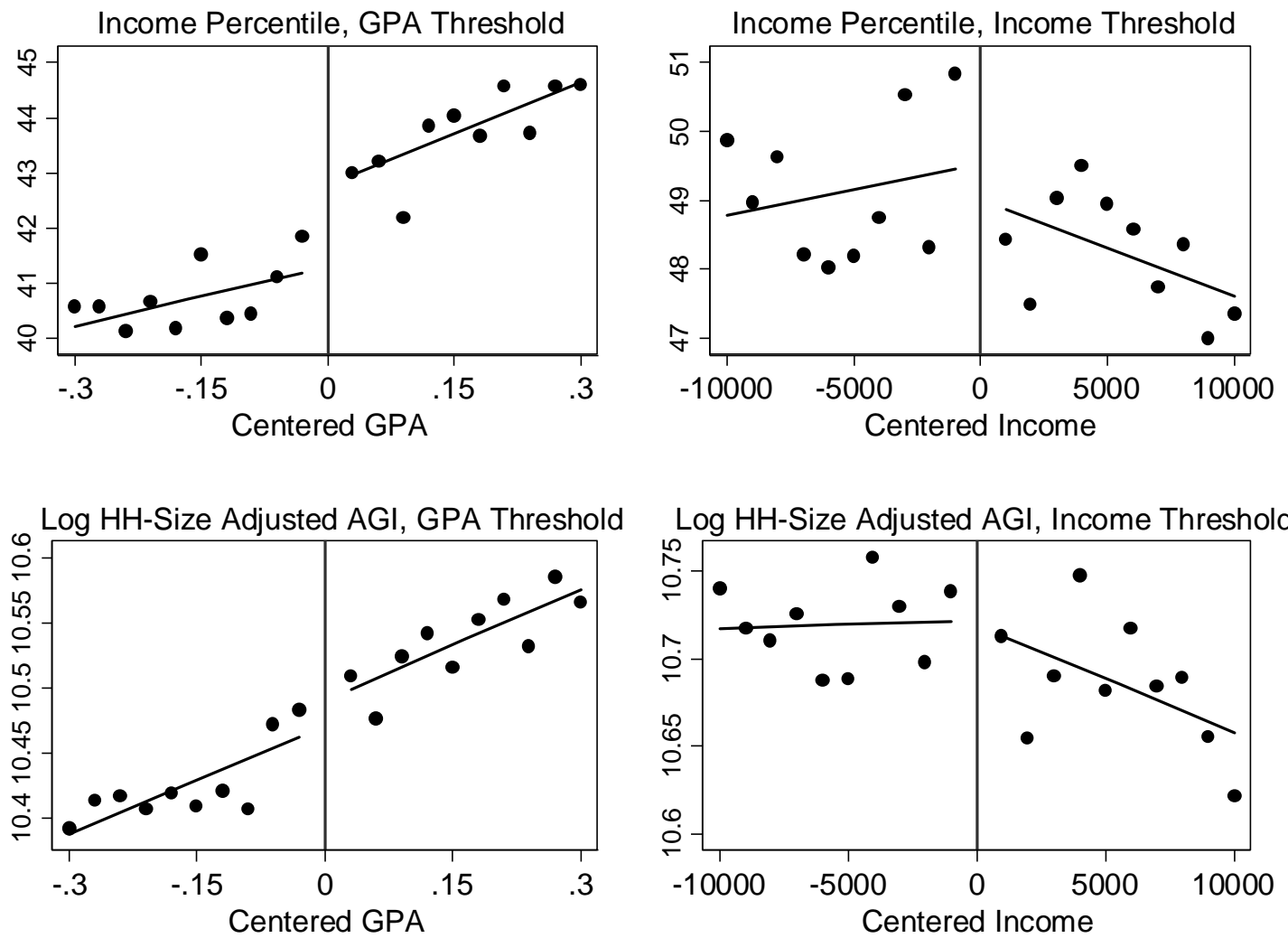

Notes: These figures plot income percentiles (top panel) and household size-adjusted AGI (bottom panel) averaged over 10 and 14 years since their Cal Grant application, pooled over cohorts. Students are binned by 0.03 GPA points or $\$ 1,000$ relative to the year-specific eligibility threshold at the GPA and income thresholds, respectively. Income is reversed so that values above the cutoff represent lower family incomes; crossing the threshold from left to right indicates becoming eligible for the Cal Grant. 

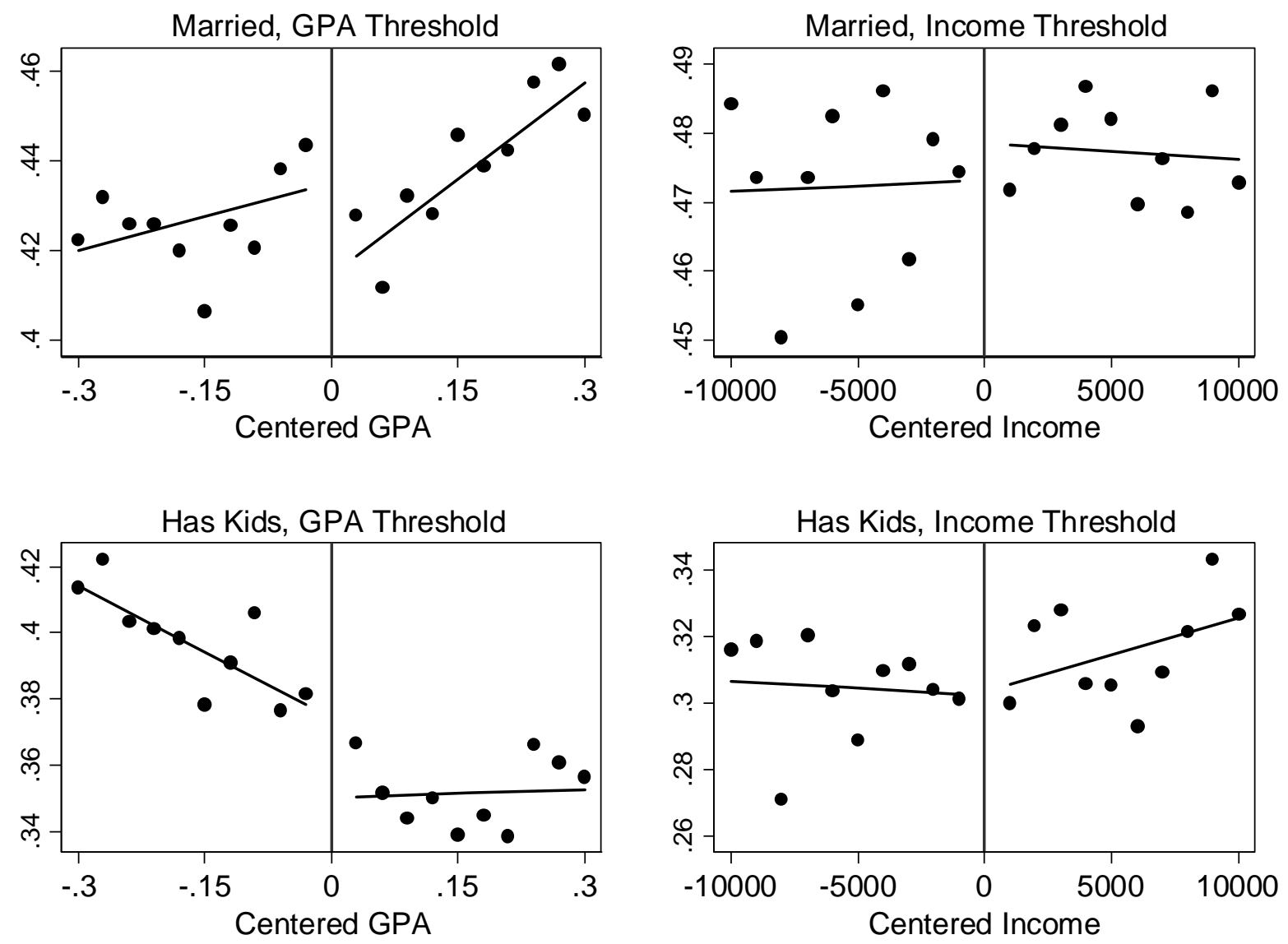

Notes: These figures plot the proportion of students who are married filing joint (top panel) and have child dependents (bottom panel) at any point between 10 and 14 years since their Cal Grant application, pooled over cohorts. Students are binned by 0.03 GPA points or $\$ 1,000$ relative to the year-specific eligibility threshold at the GPA and income thresholds, respectively. Income is reversed so that values above the cutoff represent lower family incomes; crossing the threshold from left to right indicates becoming eligible for the Cal Grant. 

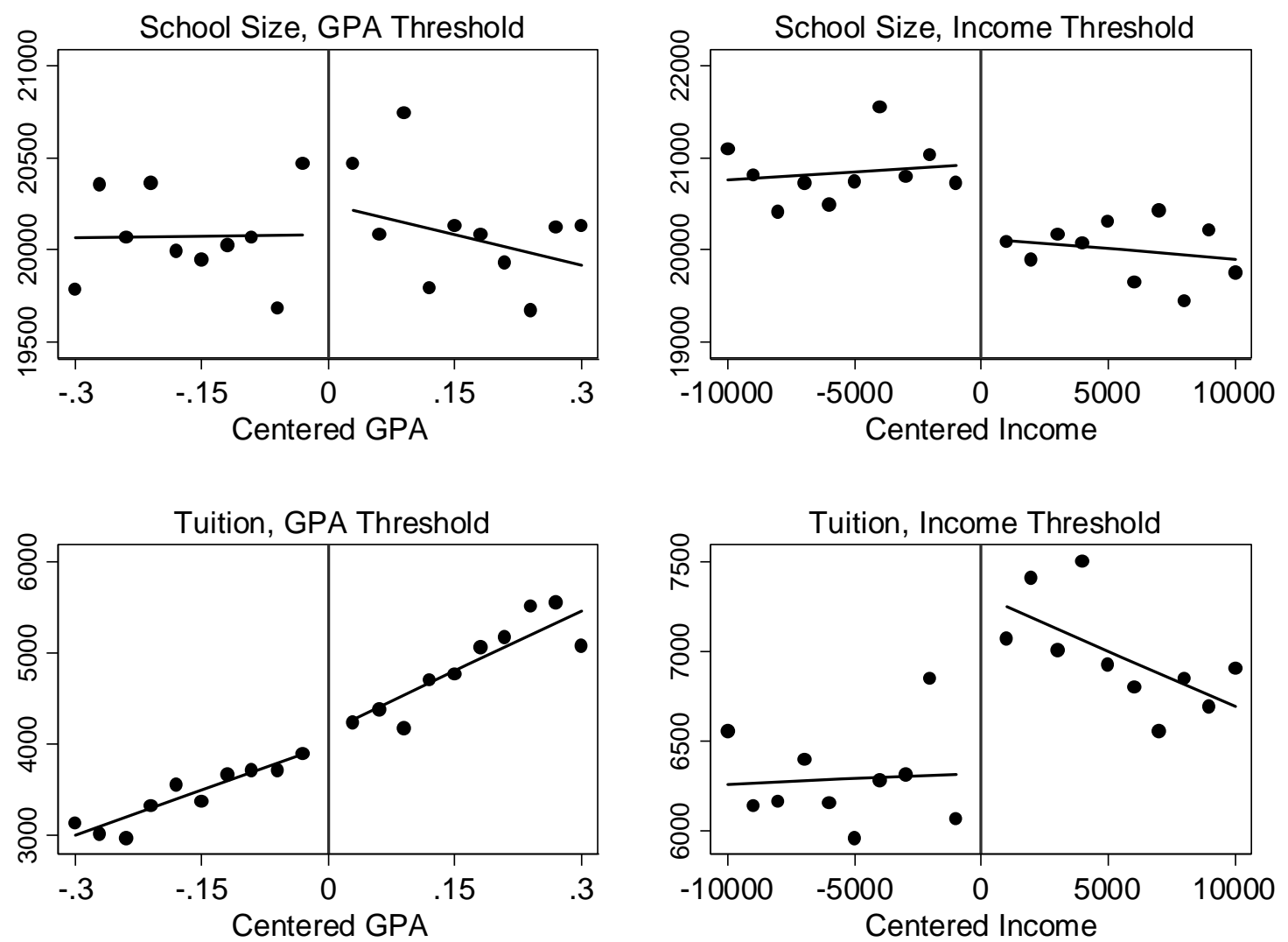

Notes: These figures plot school size (top panel) and average tuition (bottom panel) for the first observed institution in which a student enrolls within 1 to 4 years of their Cal Grant application, pooled over cohorts, based on IPEDS data. Students are binned by 0.03 GPA points or $\$ 1,000$ relative to the year-specific eligibility threshold at the GPA and income thresholds, respectively. Income is reversed so that values above the cutoff represent lower family incomes; crossing the threshold from left to right indicates becoming eligible for the Cal Grant. 
150\% Time to Graduation, GPA Threshold
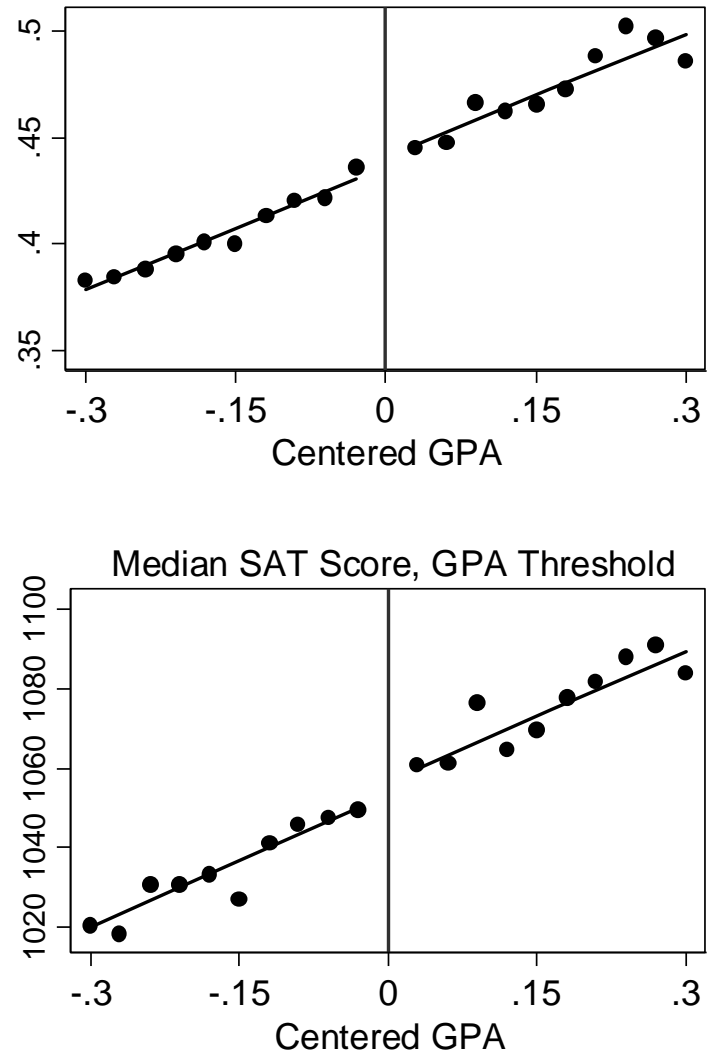

150\% Time to Graduation, Income Threshold
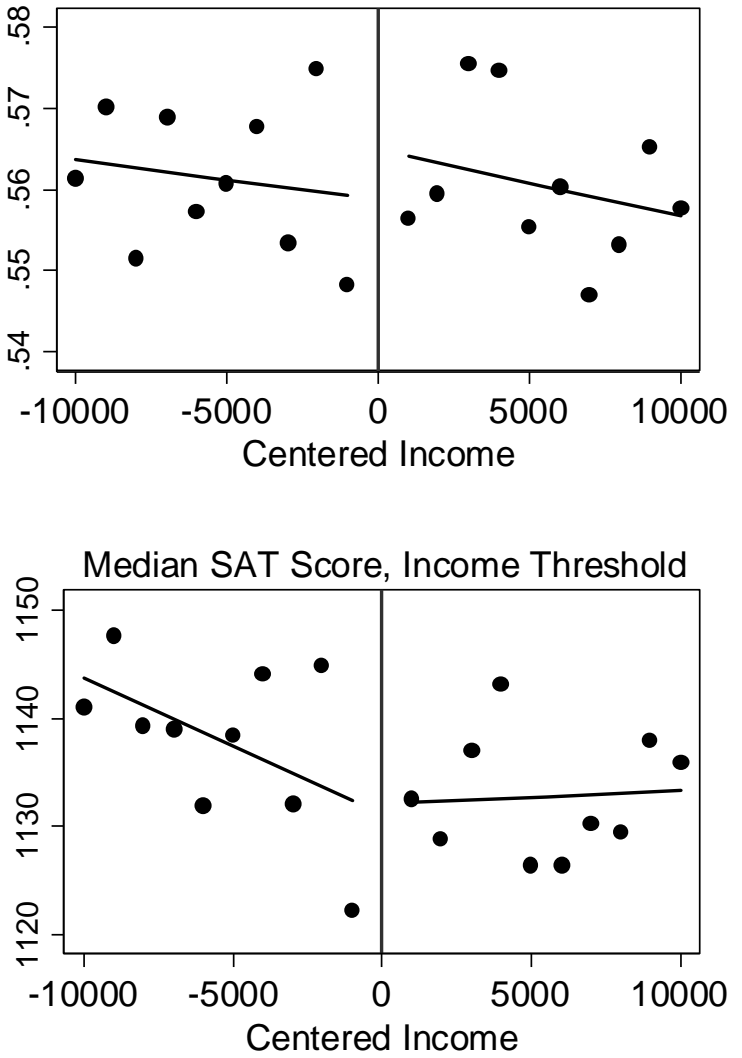

Notes: These figures plot the $150 \%$ time to graduation (top panel) and “median” SAT score (bottom panel) for the first observed institution in which a student enrolls within 1 to 4 years of their Cal Grant application, pooled over cohorts, based on IPEDS data. Median GPA is computed as the average of GPA scores at the $25^{\text {th }}$ and $75^{\text {th }}$ percentiles. Students are binned by 0.03 GPA points or $\$ 1,000$ relative to the year-specific eligibility threshold at the GPA and income thresholds, respectively. Income is reversed so that values above the cutoff represent lower family incomes; crossing the threshold from left to right indicates becoming eligible for the Cal Grant. 

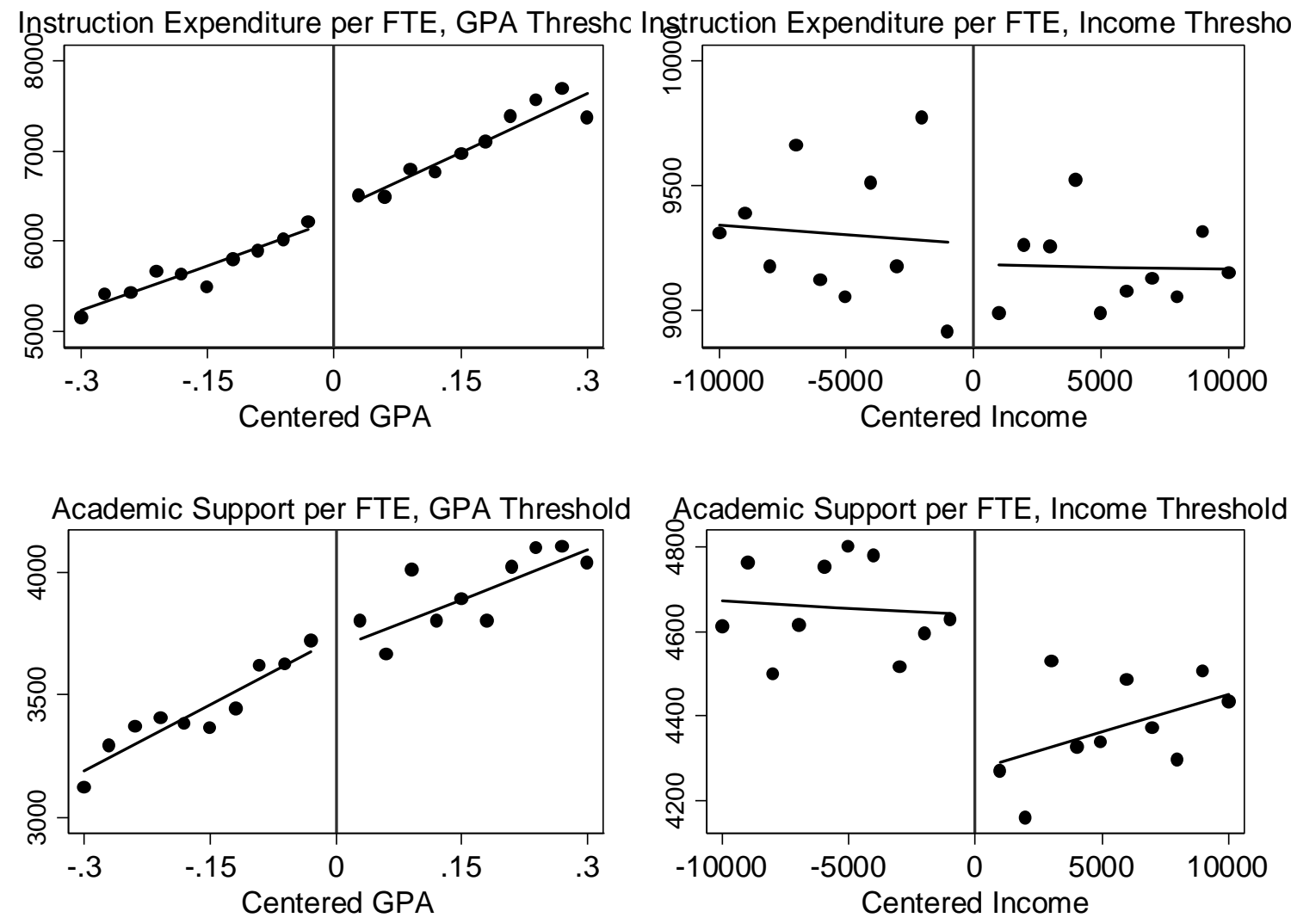

Notes: These figures plot instruction expenditures per full-time equivalent (top panel) and academic support per full-time equivalent (bottom panel) for the first observed institution in which a student enrolls within 1 to 4 years of their Cal Grant application, pooled over cohorts, based on IPEDS data. Students are binned by 0.03 GPA points or \$1,000 relative to the year-specific eligibility threshold at the GPA and income thresholds, respectively. Income is reversed so that values above the cutoff represent lower family incomes; crossing the threshold from left to right indicates becoming eligible for the Cal Grant. 

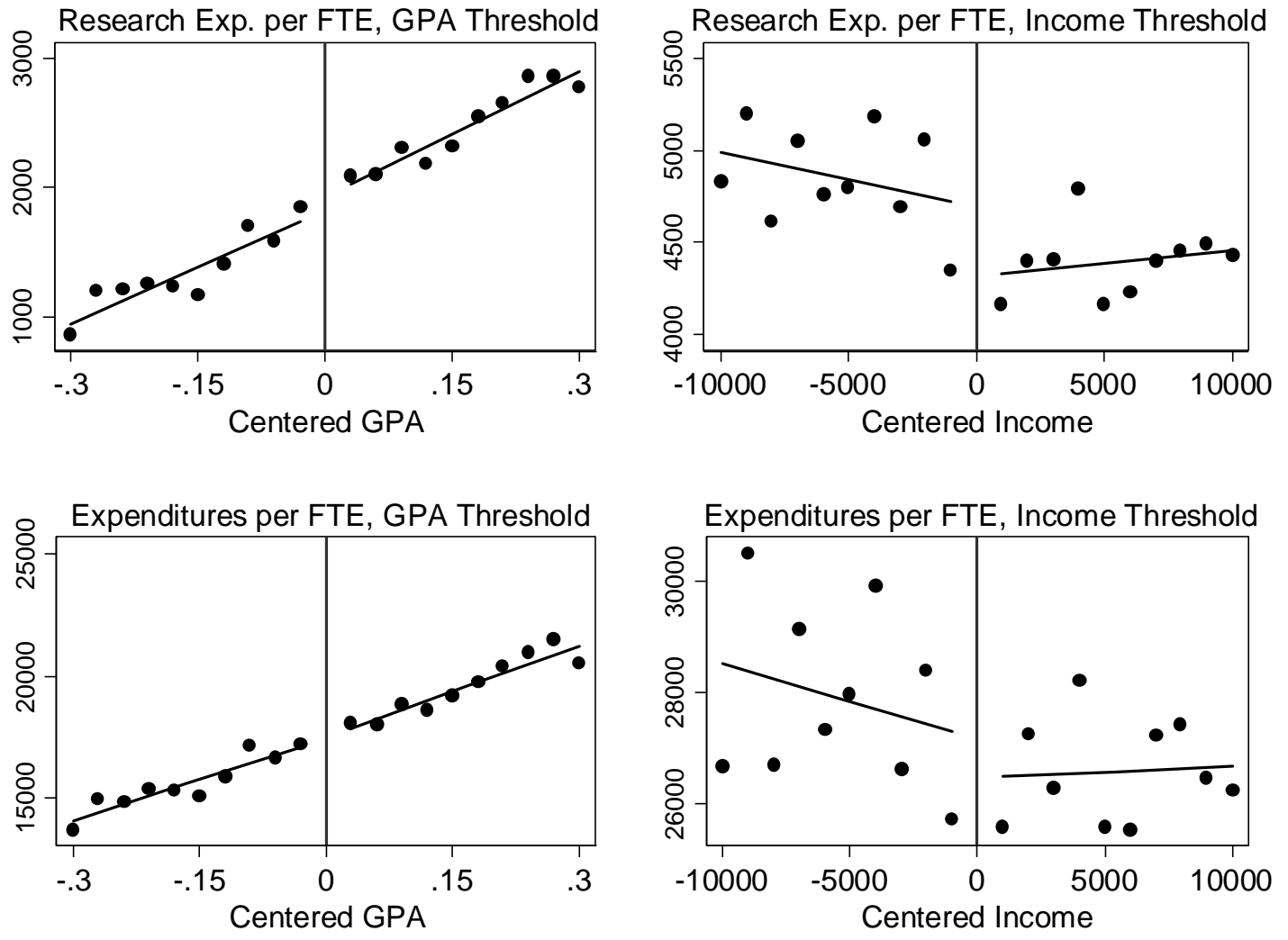

Notes: These figures plot research expenditures per full-time equivalent (top panel) and expenditures per full-time equivalent (bottom panel) for the first observed institution in which a student enrolls within 1 to 4 years of their Cal Grant application, pooled over cohorts, based on IPEDS data. Students are binned by 0.03 GPA points or $\$ 1,000$ relative to the year-specific eligibility threshold at the GPA and income thresholds, respectively. Income is reversed so that values above the cutoff represent lower family incomes; crossing the threshold from left to right indicates becoming eligible for the Cal Grant. 


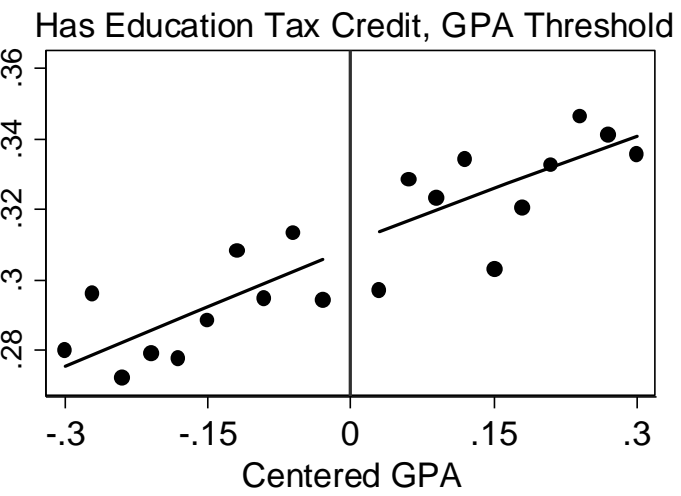

Has Education Tax Credit, Income Threshold

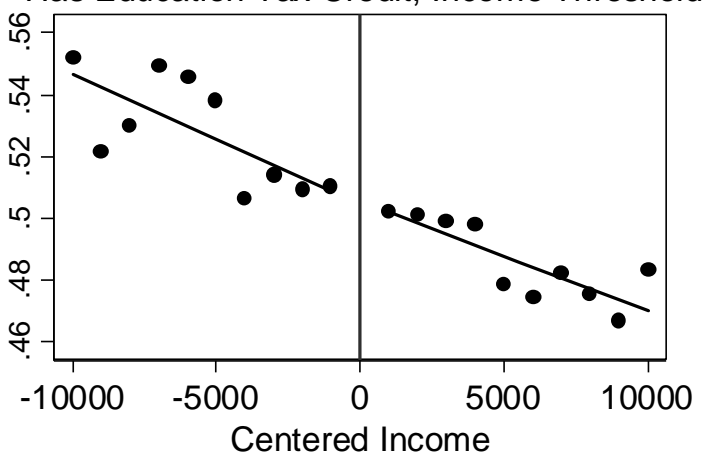

Federal Tax Credit Amount, GPA Threshold
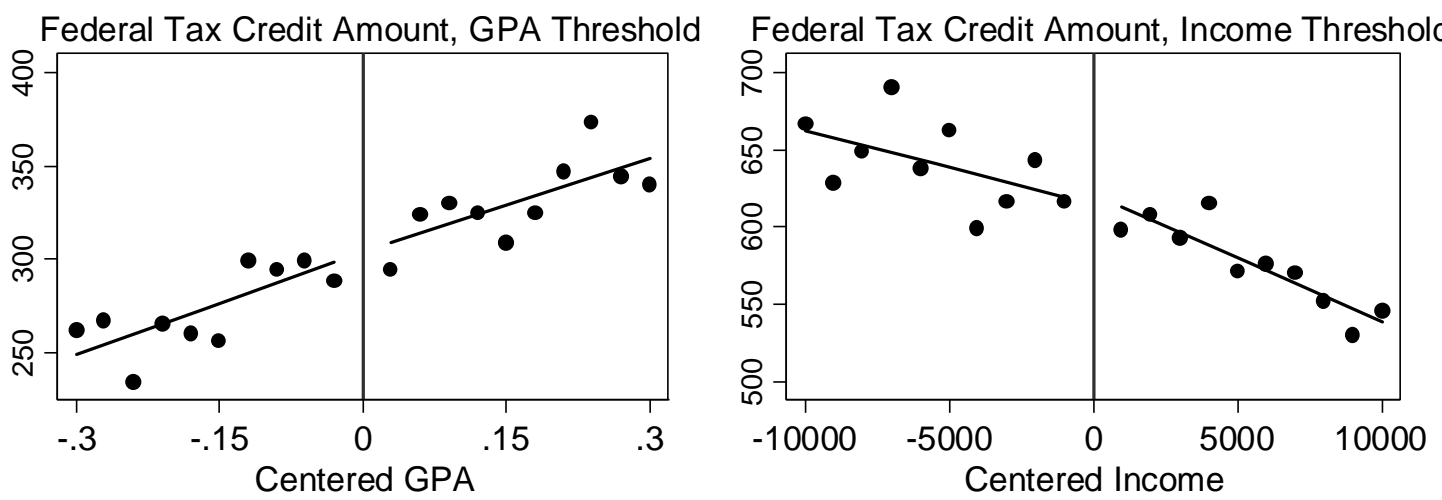

Notes: These figures plot the proportion of students' families that claim a Federal education tax credit (top panel) and average Federal education tax credit amounts (bottom panel) for within 1 to 4 years of their Cal Grant application, pooled over cohorts, based on IPEDS data. If a student is a dependent, the Federal education tax credit will be claimed by the primary filer associated with the student; we use the primary filer's tax return to gather Federal education tax credits in these cases. Students are binned by 0.03 GPA points or $\$ 1,000$ relative to the year-specific eligibility threshold at the GPA and income thresholds, respectively. Income is reversed so that values above the cutoff represent lower family incomes; crossing the threshold from left to right indicates becoming eligible for the Cal Grant. 